\title{
CDG Therapies: From Bench to Bedside
}

\author{
Sandra Brasil 1,2 (1) , Carlota Pascoal 1,2,3, Rita Francisco 1,2,3 (1) Dorinda Marques-da-Silva 1,2,3, \\ Giuseppina Andreotti 4 (iD), Paula A. Videira 1,2,3 (i), Eva Morava ${ }^{2,5}$, Jaak Jaeken ${ }^{2,6, *}$ \\ and Vanessa dos Reis Ferreira ${ }^{1,2, *}$ \\ 1 Portuguese Association for Congenital Disorders of Glycosylation (CDG), Departamento Ciências da Vida, \\ Faculdade de Ciências e Tecnologia, Universidade NOVA de Lisboa, 2820-287 Lisboa, Portugal; \\ s.arduim@gmail.com (S.B.); carlotapascoal@gmail.com (C.P.); rab.francisco@campus.fct.unl.pt (R.F.); \\ dorindams@gmail.com (D.M.-d.-S.); p.videira@fct.unl.pt (P.A.V.) \\ 2 Professionals and Patient Associations International Network (CDG \& Allies-PPAIN), \\ Departamento Ciências da Vida, Faculdade de Ciências e Tecnologia, Universidade NOVA de Lisboa, \\ 2820-287 Lisboa, Portugal; emoravakozicz@tulane.edu \\ 3 Research Unit on Applied Molecular Biosciences (UCIBIO), Departamento Ciências da Vida, \\ Faculdade de Ciências e Tecnologia, Universidade NOVA de Lisboa, 2829-516 Lisboa, Portugal \\ 4 Istituto di Chimica Biomolecolare-Consiglio Nazionale delle Ricerche (CNR), 80078 Pozzuoli, Italy; \\ gandreotti@icb.cnr.it \\ 5 Department of Clinical Genomics, Mayo Clinic, Rochester, MN 55905, USA \\ 6 Center for Metabolic Diseases, Universitaire Ziekenhuizen (UZ) and Katholieke Universiteit (KU) Leuven, \\ 3000 Leuven, Belgium \\ * Correspondence: jaak.jaeken@kuleuven.be (J.J.); sindromecdg@gmail.com (V.d.R.F.); \\ Tel.: +351-91-425-0544 (V.d.R.F.)
}

Received: 28 February 2018; Accepted: 21 April 2018; Published: 27 April 2018

\begin{abstract}
Congenital disorders of glycosylation (CDG) are a group of genetic disorders that affect protein and lipid glycosylation and glycosylphosphatidylinositol synthesis. More than 100 different disorders have been reported and the number is rapidly increasing. Since glycosylation is an essential post-translational process, patients present a large range of symptoms and variable phenotypes, from very mild to extremely severe. Only for few CDG, potentially curative therapies are being used, including dietary supplementation (e.g., galactose for PGM1-CDG, fucose for SLC35C1-CDG, $\mathrm{Mn}^{2+}$ for TMEM165-CDG or mannose for MPI-CDG) and organ transplantation (e.g., liver for MPI-CDG and heart for DOLK-CDG). However, for the majority of patients, only symptomatic and preventive treatments are in use. This constitutes a burden for patients, care-givers and ultimately the healthcare system. Innovative diagnostic approaches, in vitro and in vivo models and novel biomarkers have been developed that can lead to novel therapeutic avenues aiming to ameliorate the patients' symptoms and lives. This review summarizes the advances in therapeutic approaches for CDG.
\end{abstract}

Keywords: animal models; biomarkers; clinical trials; congenital disorders of glycosylation (CDG); diagnosis; dietary supplementation; mannose; galactose; pharmacological chaperones; therapy

\section{Introduction}

Congenital disorders of glycosylation (CDG) represent a group of genetic disorders with impaired synthesis and attachment of glycans to glycoproteins and glycolipids, and impaired synthesis of glycosylphosphatidylinositol (GPI) [1]. The more than 100 known CDG can be divided into: (a) protein $N$-glycosylation defects; (b) protein O-glycosylation defects; (c) glycolipid and GPI anchor synthesis defects and (d) multiple glycosylation pathways and other pathway defects [2-5]. 
The last category encompasses defects affecting vesicular transport, nucleotide-sugar transport or O-mannosylation, among others. The subcellular location of the defect can also be used as a complementary classification [6]. Among the different glycosylation defects, protein $\mathrm{N}$-glycosylation defects are the most common. In $\mathrm{N}$-glycosylation a glycan is first assembled as precursor attached to dolichol phosphate at the cytoplasmic side of the endoplasmic reticulum (ER) and then transferred to the amide nitrogen of an asparagine in the consensus glycosylation site (Asn-X-Ser/Thr) of the growing polypeptide in the lumen of the ER. Glycan processing (remodeling) takes place in the ER and Golgi apparatus giving rise to a complex, mature glycan [3,7]. O-glycosylation occurs in the Golgi apparatus and no lipid-linked intermediates are involved. In contrast to $N$-glycosylation, the process consists only in the sequential addition of monosacharides without remodeling and the most common structure is obtained by the addition of an $\mathrm{N}$-acetylgalactosamine (GalNAc) residue to the hydroxyl group of a serine or threonine [3,7]. Defects in the synthesis of O-linked $\mathrm{N}$-acetylglucosamine (GlcNAc), galactose (Gal), mannose (Man), glucose (Glc) and fucose (Fuc) glycans have also been described [8].

Glycosylation is essential for a variety of biological processes and thus CDG patients present highly heterogeneous clinical phenotypes that can range from mild to severe and involve single or in most cases, multiple organs [4,7]. Neurological symptoms include cognitive impairment, epilepsy, hypotonia, ataxia and polyneuropathy. Other symptoms are ophthalmological, skeletal, cardiac, hepatic, hematological and endocrinological $[3,4,9,10]$. Serum transferrin isoelectrofocusing is still the screening method of choice. An abnormal result is followed by CDG panel/whole-exome (WES)/whole genome (WGS) sequencing, among other strategies, to identify the involved gene [1,11,12].

Transferrin glycosylation patterns were also the basis for the first CDG classification (e.g., CDG-I or CDG-II). However, this nomenclature comprises only $N$-glycosylation deficiencies leaving out others, such as O-glycosylation defects (e.g., EOGT-CDG, POGLUT1-CDG or B4GALT7-CDG) [13]. Hence, a new, clear and informative nomenclature was implemented based on the name of the affected gene (not in italics) followed by "-CDG" [13]. The growing number of known CDG has stimulated research into their pathophysiological mechanisms in order to achieve better disease management and ultimately an efficient treatment. Several in vitro and in vivo disease models have been generated allowing the identification of important disease hallmarks, such as novel biomarkers and the screening and testing of possible therapeutic approaches. As a result, advances in treatment options have been made for some CDG [14-16] but the majority of CDG still remain without effective treatment.

In order to collect information about CDG for which some form of treatment already exists (in pre-clinical research, clinical development, compassionate use or approved stage) we performed an extensive search and review of the literature on the following CDG: ALG1-CDG, ALG6-CDG, ALG13-CDG, ATP6VAP1-CDG, CAD-CDG, CCDC115-CDG, DOLK-CDG, GNE-CDG, ISPD-CDG, MAGT1-CDG, MPI-CDG, NANS-CDG, PGM1-CDG, PGM3-CDG, PIGM-CDG, PIGA-CDG, PIGO-CDG, PMM2-CDG SL39A8-CDG, SLC35C1-CDG, SLC35A2-CDG, SDR5A3-CDG, TMEM165-CDG and TMEM199-CDG.

The information collected was organized in different sections namely disease models, biomarkers, dietary supplementation therapies, other therapeutic options and clinical trials registered for CDG, therefore following and reporting on therapy development from bench to bedside.

Hence, this review aims to facilitate further research and therapy development. This should help clinicians and families in disease management and treatment selection.

\section{Disease Models}

In vitro models (e.g., Chinese hamster cell lines or HeLa cell lines) have been extremely useful in CDG to identify biological processes, investigate underlying molecular mechanisms [17-21], categorize new mutations as disease-causing and assess protein functionality [22-36]. In vitro models are also often used to study the effect of disrupted enzyme activity due to a pathogenic genetic variation [33,35,37-39]. In line with this, they are used as heterologous expression systems for 
recombinant proteins, allowing the study of the impact of different variants on protein localization and activity, and also their correlation with phenotype severity [30,38,40-44]. Other important in vitro models are patient-derived cells, such as fibroblasts, leukocytes or muscle cells which have been used to test biochemical and cellular features as well as responses to potential treatments. [23,27,36,40,43,45-71]

Nevertheless in vitro models present limitations that can only be circumvented by the analysis of a model organism such as, the effect of glycosylation defects in embryonic development or the severe manifestations caused by Man supplementation on an MPI-CDG mouse model [16,72]. Moreover, pre-clinical research data concerning absorption, distribution, metabolism, excretion and toxicity (ADME-Tox) parameter obtain using in vivo models, is essential for further clinical research.

The development of new techniques such as Clustered Regularly Interspaced Short Palindromic Repeats (CRISPR)/Cas9 have made in vivo gene engineering a more accessible and affordable task [73]. One of the major concerns in producing a model organism is the recapitulation of the expected phenotype. Complete deletion of genes involved in glycosylation has caused embryonic or neonatal lethality $[74,75]$ or no disease phenotype [76], while the generation of hypomorphic models has yielded similar results [77].

Thus, animal models that replicate the phenotypes of patients are necessary to assess safety and efficacy of new therapeutic approaches for CDG. Despite the difficulties encountered in generating efficient in vivo models, advances have been made that have allowed a better understanding of the pathophysiological mechanisms underlying CDG and also the pre-clinical testing of compounds such as sialic acid (SA), [78,79], $N$-acetylmannosamine (ManNAc) [78,80-82], peracetylated $\mathrm{N}$-acetylmannosamine ( $\mathrm{Ac}_{4} \mathrm{ManNAc}$ ) [83], and 6'-sialyllactose [84] for GNE-CDG.

Several species and engineering techniques have been used in attempts to generate suitable disease models for CDG (Table 1). Several other possible mouse models for CDG are under construction (e.g., C57BL/6NJ-C57BL/6NJ-Alg8/Mmjax, C57BL/6NJ-C57BL/6NJ-Alg9/Mmjax or 024331-B6N(Cg)-Alg2/J) by the Knockout Mouse Project (KOMP) as part of the International Mouse Phenotyping Consortium effort to generate and characterize 5000 targeted knockout mouse lines $[85,86]$. 
Table 1. Overview of congenital disorders of glycosylation (CDG) disease models.

\begin{tabular}{|c|c|c|c|c|c|}
\hline Defect & CDG/Protein & Cell/Organism/Animal & Model & Major Findings/Phenotype & Reference \\
\hline \multirow{7}{*}{$\begin{array}{l}\text { Protein } \\
N \text {-glycosylation }\end{array}$} & \multirow[t]{2}{*}{$\begin{array}{l}\text { ALG1-CDG/Chitobiosyldiphosphodolichol } \\
\beta \text {-mannosyltransferase }\end{array}$} & Saccharomyces cerevisiae & Alg1 mutants (K57-6C strain) & $\begin{array}{l}\text {-Thermosensitive. } \\
\text {-Increased levels of GDP-Man by Mannose-1-phosphate } \\
\text { guanylyltransferase (MPG1) gene overexpression restores defects in } \\
\text { mannosylation, in contrast to Man supplementation. }\end{array}$ & {$[24,34,41]$} \\
\hline & & S. cerevisiae & Alg1 mutants (PRY56 strain) & -Thermosensitive. & [31] \\
\hline & \multirow[t]{2}{*}{ ALG6-CDG/ $\alpha-1,3$-glucosyltransferase } & S. cerevisiae & Alg6 mutants & $\begin{array}{l}\text {-Unable to transfer glucose from dolichol phosphoglucose in the } \\
\text { Lipid-linked oligosaccharides (LLO) synthesis leading to the } \\
\text { accumulation of Man, GlcNAc. } \\
\text {-Shorter LLO glucose chain causes growth defects. } \\
\text {-Alg6 mutants stopped growing completely. }\end{array}$ & {$[87,88]$} \\
\hline & & $\begin{array}{l}\text { Chinese hamster }(\mathrm{CHO}) \\
\text { cell line }\end{array}$ & MI8-5 cells $\left(\right.$ Alg6 $\left.^{-/-}\right)$ & -Unable to synthetize glucosylated oligosaccharides. & [89] \\
\hline & \multirow{3}{*}{ MAGT1-CDG/Magnesium transporter 1} & $\begin{array}{l}\text { Human embryonic } \\
\text { kidney (HEK293) } \\
\text { cell line }\end{array}$ & Magt1 knockdown by siRNA & $\begin{array}{l}\text {-Decreased } \mathrm{Mg}^{2+} \text { uptake. } \\
\text {-Combined Magt1 and TUSC3 overexpression raised cellular } \\
\mathrm{Mg}^{2+} \text { content. }\end{array}$ & [90] \\
\hline & & S. cerevisiae & Alr1 $\Delta$ strain & $\begin{array}{l}\text {-Inability to proliferate in } \mathrm{Mg}^{2+} \text { free medium is overcome by } \\
\text { magt1 complementation. }\end{array}$ & [90] \\
\hline & & Dario renio (zebrafish) & $\begin{array}{l}\text { (a) Zygotic Magt1 knockdown } \\
\text { (b) Maternal and zygotic } \\
\text { Magt1 knockdown }\end{array}$ & $\begin{array}{l}\text { (a) Embryonic lethality. Profound developmental abnormalities. } \\
\text { (b) Inability to hatch. } \mathrm{MgCl}_{2} \text { recovered lethality. }\end{array}$ & [90] \\
\hline \multirow{5}{*}{$\begin{array}{l}\text { Protein } \\
N \text {-glycosylation }\end{array}$} & \multirow{4}{*}{ MPI-CDG/Mannose-6-phosphate isomerase } & $\begin{array}{l}\text { Human colon } \\
\text { adenocarcinoma } \\
\text { (HT-29) cell line }\end{array}$ & Mpi knockdown by siRNA & -Inhibiting $M p i$ by $50-70 \%$ increases Man incorporation into proteins. & [59] \\
\hline & & Mus musculus (mouse) & $\operatorname{Mpi}\left(\mathrm{Mpi}^{-/-}\right)$knockout & $\begin{array}{l}\text {-Normal glycosylation profile. } \\
\text {-High level of embryonic lethality that was exacerbated by Man } \\
\text { supplementation due to Man-6-P accumulation and a decrease in } \\
\text { adenosine triphosphate (ATP) levels. }\end{array}$ & [91] \\
\hline & & Mouse & Hypomorphic Mpi ${ }^{\mathrm{Y} 255 \mathrm{C} / \mathrm{Y} 255 \mathrm{C}}$ & $\begin{array}{l}\text {-Reduced in utero mortality which was increased by mannose } \\
\text { supplementation to the pregnant dams. The surviving offspring } \\
\text { presented severe ocular defects. } \\
\text {-No phenotypic presentations. }\end{array}$ & [72] \\
\hline & & Zebrafish & $\begin{array}{l}\text { Mpi mutant with } 13 \% \text { of } \\
\text { enzymatic activity }\end{array}$ & $\begin{array}{l}\text {-MPI-CDG biochemical and phenotypic presentations. } \\
\text {-Addition of mannose to the fish water rescued mpi morphants } \\
\text { phenotype but only if provided prior to } 24 \mathrm{~h} \text { post fecundation (hpf). }\end{array}$ & [92] \\
\hline & PMM2-CDG/Phosphomannomutase 2 & $\begin{array}{l}\text { Human induced } \\
\text { pluripotent stem cells } \\
\text { (iPSC) }\end{array}$ & 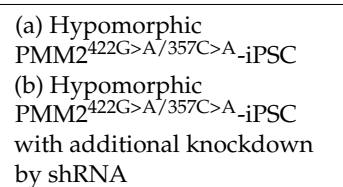 & $\begin{array}{l}\text {-Reduced PMM activity, accumulation of shorter glycan structures } \\
\text { and reduced mannosylation (b) with a more severe phenotype. }\end{array}$ & [93] \\
\hline
\end{tabular}


Table 1. Cont.

\begin{tabular}{|c|c|c|c|c|c|}
\hline Defect & CDG/Protein & Cell/Organism/Animal & Model & Major Findings/Phenotype & Reference \\
\hline $\begin{array}{l}\text { Protein } \\
N \text {-glycosylation }\end{array}$ & PMM2-CDG/Phosphomannomutase 2 & Mouse & Knockout & -Incompatible with life. & [75] \\
\hline \multirow{5}{*}{$\begin{array}{l}\text { Protein } \\
N \text {-glycosylation }\end{array}$} & \multirow{5}{*}{ PMM2-CDG/Phosphomannomutase 2} & Mouse & $\begin{array}{l}\text { (a) Homozygous } \\
\text { Pmm2 } 137 \mathrm{H} / \mathrm{R} 137 \mathrm{H} \\
\text { (b) Homozygous } \\
\text { Pmm2 } 2^{\mathrm{F} 118 \mathrm{~L} / \mathrm{F} 118 \mathrm{~L}} \\
\text { (c) Heterozygous } \\
\text { Pmm2 }\end{array}$ & $\begin{array}{l}\text { (a) Embryonic lethality. } \\
\text { (b) Viable with no phenotype. } \\
\text { (c) Embryonic lethality recovered by oral Man administration to } \\
\text { pregnant dams. }\end{array}$ & [77] \\
\hline & & Mouse & $\begin{array}{l}\text { Heterozygous } \\
\text { Pmm2 } 2^{\text {Ri37H/F115L }}\end{array}$ & $\begin{array}{l}\text {-Prenatal lethality which could not be restored with } \\
\text { Man supplementation. } \\
\text {-Survival mice presented delayed growth and impaired general } \\
\text { protein glycosylation. }\end{array}$ & [94] \\
\hline & & Zebrafish & Pmm2 knockout & $\begin{array}{l}\text {-Reduced Pmm2 enzymatic activity, decreased LLO levels and } \\
\text { Man-6-P accumulation. } \\
\text {-Impaired motility and altered craniofacial cartilage development. }\end{array}$ & [95] \\
\hline & & Drosophila melanogaster & $\begin{array}{l}\text { Pmm2-null mutant using } \\
\text { CRISPR/Cas9 }\end{array}$ & $\begin{array}{l}\text {-Reduced lifespan, psychomotor retardation and impairment of the } \\
\text { synaptic matrix metalloproteinase (MMP) pathway. }\end{array}$ & [96] \\
\hline & & D. melanogaster & $\begin{array}{l}\text { Pmm2 knockdown adults } \\
\text { using RNAi }\end{array}$ & -Severe ataxia, loss of coordination and inability to fly. & [96] \\
\hline \multirow{2}{*}{$\begin{array}{l}\text { Multiple and other } \\
\text { glycosylation } \\
\text { pathways }\end{array}$} & \multirow{2}{*}{$\begin{array}{l}\text { ATP6AP1-CDG/Accessory subunit of the } \\
\text { vacuolar (V)-ATPase protein pump }\end{array}$} & S. cerevisiae & voa1::H vma21QQ strain & $\begin{array}{l}\text {-Voa1 is the yeast homologue for human ATPase } \mathrm{H}^{+} \text {transporting } \\
\text { accessory protein } 1 \text { (ATP6AP1). } \\
\text {-E356K and Y313C mutations compromise cell growth. }\end{array}$ & [97] \\
\hline & & Zebrafish & Homozygous Atp6ap1 $1 b^{a 82 / a 82}$ & -Pigmentation defects. & [98] \\
\hline \multirow{4}{*}{$\begin{array}{l}\text { Multiple and other } \\
\text { glycosylation } \\
\text { pathways }\end{array}$} & \multirow[t]{2}{*}{$\begin{array}{l}\text { ATP6AP1-CDG/Accessory subunit of the } \\
\text { vacuolar (V)-ATPase protein pump }\end{array}$} & Zebrafish & $\begin{array}{l}\text { (a) Zygotic Atp6ap1b } \\
\text { knockdown } \\
\text { (b) Maternal and zygotic } \\
\text { Atp6ap1b knockdown }\end{array}$ & $\begin{array}{l}\text { (a) Eye abnormalities at 3-5 days of development. } \\
\text { (b) Reduced development of precursor cells (DFCs) which resulted in } \\
\text { smaller Kupffer's vesicle (KV) organ size, due to reduced KV cell } \\
\text { number. Defects in the development of ciliated organs, spaw and } \\
\text { heart laterality defects were also observed. Loss of Atp6ap1b led to } \\
\text { V-ATPase mislocalization and affected DFCs pH. }\end{array}$ & [98] \\
\hline & & Mouse & $\begin{array}{l}\text { Chimeric model with reduced } \\
\text { Atp6ap1 (ac45) expression }\end{array}$ & -One chimeric female that died approximately 6 weeks after birth. & [99] \\
\hline & \multirow[t]{2}{*}{$\begin{array}{l}\text { CAD-CDG/Enzyme complex (ATase, } \\
\text { CPSase, ATCase and DHOase) }\end{array}$} & CHO cell line & $\begin{array}{l}\text { CHO-G9C } \\
\text { CAD-deficient cells }\end{array}$ & $\begin{array}{l}\text {-Reduced levels of uridine diphosphate- } N \text {-acetylglucosamine } \\
\text { (UDP-GlcNAc), UDP- } N \text {-acetylgalactosamine (UDP-GalNAc), } \\
\text { UDP-galactose (UDP-Gal), UDP-glucose (UDP-Glc), uridine } \\
\text { triphosphate (UTP) and cytosine triphosphate (CTP) (restored by } \\
\text { addition of exogenous uridine) as well as less aspartate } \\
\text { incorporation into nucleic acids which led to defective growth. }\end{array}$ & [100] \\
\hline & & Caenorhabditis elegans & pyr-1(cu8) mutant & $\begin{array}{l}\text {-Maternal effect (mother environment and genotype } \\
\text { influence) lethality. } \\
\text {-Defective pharynx development. } \\
\text { Cytoskeletal organization defects. }\end{array}$ & [101] \\
\hline
\end{tabular}


Table 1. Cont.

\begin{tabular}{|c|c|c|c|c|c|}
\hline Defect & CDG/Protein & Cell/Organism/Animal & Model & Major Findings/Phenotype & Reference \\
\hline $\begin{array}{l}\text { Multiple and other } \\
\text { glycosylation } \\
\text { pathways }\end{array}$ & $\begin{array}{l}\text { CAD-CDG/Enzyme complex (ATase, } \\
\text { CPSase, ATCase and DHOase) }\end{array}$ & D. melanogaster & Rudimentary mutant & $\begin{array}{l}\text {-High sterility levels in homozygous females. } \\
\text {-Reduced viability and defective wing morphogenesis. } \\
\text {-Increased survival after uridine, orotic acid, free uracil and } \\
\text { carbamoyl aspartic acid supplementation. }\end{array}$ & [102] \\
\hline \multirow{5}{*}{$\begin{array}{l}\text { Multiple and other } \\
\text { glycosylation } \\
\text { pathways }\end{array}$} & \multirow{2}{*}{$\begin{array}{l}\text { CAD-CDG/Enzyme complex (ATase, } \\
\text { CPSase, ATCase and DHOase) }\end{array}$} & Zebrafish & Perplexed $\left(p l x^{a 52}\right)$ mutant & $\begin{array}{l}\text {-Impaired retinal, tectal fin and jaw morphogenesis. } \\
\text {-Phenotype rescue by pyrimidine treatment. }\end{array}$ & [103] \\
\hline & & Zebrafish & $\begin{array}{l}\text { Transgenic } T g(p 2 x r 3.2: g f p)^{s l 23} \\
\text { mutant }\end{array}$ & $\begin{array}{l}\text {-Cranial sensory circuit malformation. } \\
\text {-Small eyes and deformed jaws. } \\
\text {-Orotic acid or uridine treatment failed to rescue phenotype. }\end{array}$ & [104] \\
\hline & \multirow[t]{2}{*}{$\begin{array}{l}\text { CCDC115-CDG/Coiled-coil } \\
\text { domain-containing protein } 115\end{array}$} & S. cerevisiae & $\begin{array}{l}\text { HY13 (vma22 } \triangle:: \text { LEU2) } \\
\text { KHY34 } \\
\text { (vma22 } \Delta:: \text { LEU2 pep4-3) } \\
\text { KHY38 (vma22 }:: \text { URA3) } \\
\text { KHY39 } \\
\text { (vma22 } \Delta:: \text { URA3 pep4-3) }\end{array}$ & $\begin{array}{l}\text {-No vacuolar ATPase activity. } \\
\text {-Normal production of } V_{1} \text { subunits, but lack of association to the } \\
\text { vacuolar membrane. } \\
\text {-Destabilization of Vph1p and Vma3p/Vma11p subunits. }\end{array}$ & [105] \\
\hline & & HeLa cell line & $\begin{array}{l}\text { CCDC115 knockdown using } \\
\text { CRISPR/Cas9 }\end{array}$ & $\begin{array}{l}\text {-Impaired iron(II) prolyl hydroxylase (PHD) activity and } \\
\text { hypoxia-inducible factor } 1(\mathrm{HIF} 1 \alpha) \text { activation. }\end{array}$ & {$[106]$} \\
\hline & DOLK-CDG/Dolichol kinase & S. cerevisiae & Sec59 mutant & $\begin{array}{l}\text {-Sec59, the homologue of human dolichol kinase (DOLK), catalyzes } \\
\text { the phosphorylation of the dolichol lipid carrier. } \\
\text {-Thermosensitive. }\end{array}$ & {$[18,29]$} \\
\hline \multirow{5}{*}{$\begin{array}{l}\text { Multiple and other } \\
\text { glycosylation } \\
\text { pathways }\end{array}$} & \multirow{5}{*}{$\begin{array}{l}\text { GNE-CDG/UDP-GlcNAc } \\
\text { 2-epimerase/ManNAc kinase }\end{array}$} & $\mathrm{CHO}$ cell line & Gne-deficient lec3 mutant & $\begin{array}{l}\text {-Reduced NCAM polysialic acid content. } \\
\text {-Lec3 cells are defective in GNE activity. } \\
\text {-Sialylation defects were rescued by ManNAc and manosamine } \\
\text { complementation. } \\
\text {-Expression of Gne mutation M712T is responsible for less celular and } \\
\text { glycoprotein-linked sialic acid content (HIBM) whereas R-236L and } \\
\text { R266Q produce higher amounts than WT (sialuria). }\end{array}$ & {$[19,26,28,107,108]$} \\
\hline & & HEK293 cell line & $\begin{array}{l}\text { (a) D176V-Gne mutant } \\
\text { (b) V572L-Gne mutant } \\
\text { (c) Gne knockdown by shRNA }\end{array}$ & $\begin{array}{l}\text {-(a), (b) and (c) have decreasingly levels of sialylation of membrane } \\
\text { and cytosolic protein, restored by supplementation with Neu5Ac } \\
\text { (SA) and ManNAc. } \\
-\beta \text {-integrin hyposialylation leads to increased cell adhesion. }\end{array}$ & {$[39,109]$} \\
\hline & & $\begin{array}{l}\text { Human promyelocytic } \\
\text { leukemia (HL60) } \\
\text { cell line }\end{array}$ & HL60-I clone & $\begin{array}{l}\text {-Increased overall surface SA content by supplementation with } \\
\text { ManNAc and ManNProp. }\end{array}$ & {$[110,111]$} \\
\hline & & $\begin{array}{l}\text { Spodoptera frugiperda } \\
\text { (Sfg) cell line }\end{array}$ & M712T Gne & $\begin{array}{l}\text {-Reduced activity but not overall sialylation, indicating that disease } \\
\text { is not directly caused by lack of SA. }\end{array}$ & [40] \\
\hline & & $\begin{array}{l}\text { Embryonic stem } \\
\text { cells (ESC) }\end{array}$ & Mice $G N E^{-/-}$ESC & $\begin{array}{l}\text {-Impaired proliferation, differentiation and altered genetic } \\
\text { expression. } \\
\text {-Smaller embryonic bodies size which was corrected by the presence } \\
\text { of SA. }\end{array}$ & {$[74,112-115]$} \\
\hline
\end{tabular}


Table 1. Cont.

\begin{tabular}{|c|c|c|c|c|c|}
\hline Defect & CDG/Protein & Cell/Organism/Animal & Model & Major Findings/Phenotype & Reference \\
\hline \multirow{7}{*}{$\begin{array}{l}\text { Multiple and other } \\
\text { glycosylation } \\
\text { pathways }\end{array}$} & \multirow{7}{*}{$\begin{array}{l}\text { GNE-CDG/UDP-GlcNAc 2-epimerase/ } \\
\text { ManNAc kinase }\end{array}$} & Mouse & $G n e^{-/-}$ & -Incompatible with life. & [74] \\
\hline & & Mouse & $G n e^{-/+}$ & -No disease phenotype. & [116] \\
\hline & & Mouse & $\begin{array}{l}\text { Gne } e^{\mathrm{M} 712 \mathrm{~T} / \mathrm{M} 712 \mathrm{~T}} \text { in a } \\
\text { C57BL/6J background }\end{array}$ & $\begin{array}{l}\text {-High lethality within the first } 72 \mathrm{~h} \text { after birth, which was prevented } \\
\text { by oral administration of ManNAc to the pregnant and nursing } \\
\text { dams. } \\
\text {-Muscle hyposialylation at an adult ( } 4 \text { to } 6 \text { months) age. } \\
\text {-Renal phenotype. }\end{array}$ & {$[81,117]$} \\
\hline & & Mouse & $\begin{array}{l}\text { Gne } e^{\mathrm{M} 712 \mathrm{~T} / \mathrm{M} 712 \mathrm{~T}} \text { in a mixed } \\
\text { genetic background } \\
(129 \mathrm{~Sv} / \mathrm{ICR})\end{array}$ & $\begin{array}{l}\text {-High survival rate. } \\
\text {-No renal phenotype. } \\
\text {-No muscle deterioration up to } 18 \text { months of age. }\end{array}$ & [76] \\
\hline & & Mouse & $\begin{array}{l}\text { Transgenic mouse } \\
\left(\text { Gne } \mathrm{e}^{(-/-)} \mathrm{h} G N E D 176 \mathrm{~V}-\mathrm{Tg}\right)\end{array}$ & $\begin{array}{l}\text {-Decreased levels of SA in different organs. } \\
\text {-Adult onset with muscle pathology. } \\
\text { - } \beta \text {-amyloid deposits in the muscles, but not in the CNS. }\end{array}$ & {$[118,119]$} \\
\hline & & Mouse & Gne $e^{\text {572L/V572L }}$ & -Renal phenotype that was corrected by SA administration. & [79] \\
\hline & & Mouse & $\begin{array}{l}\text { Transgenic } \\
\text { FVBN-GNR-R263L }\end{array}$ & $\begin{array}{l}\text {-Sialuria with elevated SA in urine. } \\
\text {-Increased neural cell adhesion molecule (NCAM) polysialylation. } \\
\text {-Increased cell surface sialylation in leucocytes. }\end{array}$ & [120] \\
\hline \multirow{4}{*}{$\begin{array}{l}\text { Multiple and other } \\
\text { glycosylation } \\
\text { pathways }\end{array}$} & $\begin{array}{l}\text { GNE-CDG/UDP-GlcNAc } \\
\text { 2-epimerase/ManNAc kinase }\end{array}$ & Zebrafish & Gne knockout & $\begin{array}{l}\text {-High mortality levels. } \\
\text {-Impaired muscle structure and development with consequent } \\
\text { decreased locomotor activity. } \\
\text {-Slightly reduced GNE enzymatic activity. }\end{array}$ & [121] \\
\hline & $\begin{array}{l}\text { NANS-CDG/CMP- } N \text {-acetylneuraminic } \\
\text { acid synthetase }\end{array}$ & Zebrafish & Nansa and Nansb knockdown & $\begin{array}{l}\text {-Nansb disruption did not generated a disease phenotype. } \\
\text {-Nansa morphant embryos displayed a small head with a complex } \\
\text { phenotype, pericardial edema and skeletal developmental } \\
\text { impairment. } \\
\text {-Addition of SA to the zebrafish water resulted in partial rescue of } \\
\text { the skeletal phenotype but only if added } 24 \text { hpf. }\end{array}$ & [122] \\
\hline & PGM1-CDG/Phosphogluco-mutase 1 & Hela cell line & $\begin{array}{l}P g m 1 \text { and } L D B 3 \text { two hybrid } \\
\text { system }\end{array}$ & $\begin{array}{l}\text {-DC-related LDB3 mutations impair binding of PGM1 to Z-band } \\
\text { alternatively spliced PDZ-motif (ZASP)/Cypher. } \\
\text {-PGM/PMM domain IV of PGM1 is essential for recruitment of } \\
\text { ZASP/Cypher. }\end{array}$ & [123] \\
\hline & PGM3-CDG/Phosphogluco-mutase 3 & Mouse & $\begin{array}{l}\text { (a) Hypomorphic }\left(P g m 3^{m l d 1}\right) \\
\text { (b) Null }\left(P g m 3^{g t}\right)\end{array}$ & $\begin{array}{l}\text { (a) Embryonic lethality. } \\
\text { (b) Reduced viability with no major alteration in general protein } \\
\text { glycosylation, except for the testis-specific isoform of } \\
\text { angiotensin-converting enzyme (ACE). Reduced size, mild anemia, } \\
\text { splenomegaly, thrombocytopenia, glomerulonephritis and low B- } \\
\text { and T-cell numbers. }\end{array}$ & [124] \\
\hline
\end{tabular}


Table 1. Cont.

\begin{tabular}{|c|c|c|c|c|c|}
\hline Defect & CDG/Protein & Cell/Organism/Animal & Model & Major Findings/Phenotype & Reference \\
\hline \multirow{9}{*}{$\begin{array}{l}\text { Multiple and other } \\
\text { glycosylation } \\
\text { pathways }\end{array}$} & \multirow{3}{*}{ SLC35A1-CDG/CMP-sialic acid transporter } & CHO cell line & Lec2 (Slc35a1) mutants & $\begin{array}{l}\text {-Asialo phenotype at the cell membrane and unable to translocate } \\
\text { CMP-SA to the lumen of the Golgi. } \\
\text {-When combined with large overexpression, the } \alpha \text {-DG is functionally } \\
\text { glycosylated. }\end{array}$ & {$[17,25,26,38,125]$} \\
\hline & & CHO cell line & MAR-11 mutant & -Decreased levels of surface SA. & [126] \\
\hline & & $\begin{array}{l}\text { Near-haploid human } \\
\text { (HAP1) cell line }\end{array}$ & $\begin{array}{l}\text { Slc35a1 knockout using } \\
\text { transcription activator-like } \\
\text { effector nucleases (TALEN) }\end{array}$ & $\begin{array}{l}\text {-SLC35A1 is required for } \alpha \text {-DG mannosylation, independently from } \\
\text { sialylation. }\end{array}$ & [32] \\
\hline & \multirow{3}{*}{ SLC35A2-CDG/UDP-galactose transporter } & $\mathrm{CHO}$ cell line & Lec8(Slc35a2) deficient & $\begin{array}{l}\text {-Defective galactosylation. } \\
\text {-Gal treatment slightly increased galactosylation. }\end{array}$ & [33] \\
\hline & & MDCK-RCA ${ }^{r}$ cell line & Slc35a2 deficient & $\begin{array}{l}\text {-Defective galactosylation. } \\
\text {-UGT1 and UGT2 are localized in the Golgi the ER, respectively. } \\
\text {-UGT forms complexes with NGT and Mgats. }\end{array}$ & {$[20,21,33]$} \\
\hline & & C. elegans & Srf-3 mutants & -Reduced O- and N-linked glycans. & [127] \\
\hline & \multirow{3}{*}{ SCL35C1-CDG/GDP-fucose transporter } & CHO cell line & $\begin{array}{l}\text { Slc35c1 knockout (CHO-gmt5) } \\
\text { derived from MAR-11 } \\
\text { mutants. }\end{array}$ & $\begin{array}{l}\text {-Asialylated and afucosylated proteins due to absence of functional } \\
\text { CMP-sialic acid and GDP-fucose transporter. }\end{array}$ & {$[128,129]$} \\
\hline & & CHO cell line & $\begin{array}{l}\text { Slc35c1 disruption by zinc } \\
\text { fingers, TALEN and CRISPR } \\
\text { (CHO-gmt3) }\end{array}$ & $\begin{array}{l}\text {-Lack of functional GDP-fucose transporter. } \\
\text {-Fucose free glycoproteins. }\end{array}$ & [130] \\
\hline & & ESC cell line & Slc35c1 knockout & $\begin{array}{l}\text {-Abolishment of } \mathrm{N} \text { - and } \mathrm{O} \text {-glycoproteins fucosylation. } \\
\text {-Ricin resistant. }\end{array}$ & [131] \\
\hline \multirow{3}{*}{$\begin{array}{l}\text { Multiple and other } \\
\text { glycosylation } \\
\text { pathways }\end{array}$} & \multirow[t]{3}{*}{ SCL35C1-CDG/GDP-fucose transporter } & Mouse & $\begin{array}{l}\text { Slc35c1 }\left(\operatorname{Slc}_{3} 35 \mathrm{c1}^{-/-}\right) \\
\text {knockout }\end{array}$ & $\begin{array}{l}\text {-Elevated postnatal mortality, severe growth retardation and } \\
\text { immune system affectation. } \\
\text {-Significant reduction of fucosylated selectin ligans as well as severe } \\
\text { impairment of P-, E- and L-selectin ligand function. } \\
\text {-Defective neutrophil migration to the inflamed peritoneum, reduced } \\
\text { leukocyte rolling to inflamed muscle venules and absent lymphocyte } \\
\text { homing to lymph nodes but normal homing of lymphocytes to the } \\
\text { spleen. Normal very long chain polyunsaturated fatty acids } \\
\text { (VLC-PUFAs) levels. }\end{array}$ & [132-134] \\
\hline & & Zebrafish & $\begin{array}{l}\text { Slytherin (srn) mutant with a } \\
\text { point mutation }\end{array}$ & $\begin{array}{l}\text {-Bent tail that became progressively more severe. } \\
\text {-Reduced protein fucosylation in CNS and other tissues. } \\
\text {-Reduced number of neurons and glia cells. } \\
\text {-Signaling reduction in the Notch-Delta pathway leading to defective } \\
\text { neuromuscular synaptogenesis. }\end{array}$ & {$[135,136]$} \\
\hline & & Zebrafish & $\begin{array}{l}\text { Slc35c1 protein } \\
\text { over-expression }\end{array}$ & $\begin{array}{l}\text {-Increased N-linked fucosylation and disruption of embryonic } \\
\text { patterning. } \\
\text {-Negative regulation of Wnt signaling. }\end{array}$ & [137] \\
\hline
\end{tabular}


Table 1. Cont

\begin{tabular}{|c|c|c|c|c|c|}
\hline Defect & CDG/Protein & Cell/Organism/Animal & Model & Major Findings/Phenotype & Reference \\
\hline & \multirow[b]{2}{*}{$\begin{array}{l}\text { SLC39A8-CDG/Solute carrier family } 39 \\
\text { (zinc transporter), member 8-ZIP8 }\end{array}$} & Mouse & Slc39a $8^{-/-}$knockout & $\begin{array}{l}\text {-Impaired cardiovascular function, absence of sternum, small chest } \\
\text { cavity and a small liver. }\end{array}$ & [85] \\
\hline & & Mouse & Hypomorphic Slc39as (neo/neo) & $\begin{array}{l}\text {-Reduced mRNA and protein levels of the } \mathrm{ZIP} 8 \mathrm{Zn}^{2+} /\left(\mathrm{HCO}_{3}{ }^{-}\right)_{2} \\
\text { symporter in several tissues of the neonate mutants. } \\
\text {-Reduced zinc and iron levels. } \\
\text {-Embryonic and neonatal lethality. } \\
\text {-Surviving offspring was pale, presented growth arrest, severe } \\
\text { anemia, hypoplastic spleen, hypoplasia of liver, kidney, lung and } \\
\text { lower extremities. }\end{array}$ & {$[138,139]$} \\
\hline & SRD5A3-CDG/Steroid $5 \alpha$-reductase 3 & S. cerevisiae & Dfg10-100 & $\begin{array}{l}\text {-SRD5A3 is the human ortholog of yeast dfg10. } \\
\text {-Defective filamentous growth and carboxypeptidase Y (CPY) } \\
\text { hypoglycosylation. } \\
\text {-Defective metabolism of polyprenol to dolichol. }\end{array}$ & [140] \\
\hline \multirow{5}{*}{$\begin{array}{l}\text { Multiple and other } \\
\text { glycosylation } \\
\text { pathways }\end{array}$} & SRD5A3-CDG/Steroid $5 \alpha$-reductase 3 & Mouse & Homozygous $\left(\operatorname{Srd5a3^{Gt/Gt})}\right.$ & $\begin{array}{l}\text {-Complete embryonic lethality beyond E12.5. } \\
\text {-Homozygous embryos were smaller and displayed dilated hearts } \\
\text { and open neural tubes. } \\
\text {-Transcriptomic analysis revealed an up-regulation of the unfolded } \\
\text { protein response (UPR) and a downregulation of genes involved in } \\
\text { general cellular metabolic processes and specific embryonic } \\
\text { development. } \\
\text {-Elevated polyprenol levels. }\end{array}$ & [140] \\
\hline & \multirow{4}{*}{$\begin{array}{l}\text { TMEM165-CDG/Transmembrane } \\
\text { protein } 165\end{array}$} & S. cerevisiae & $G d t 1 \Delta$ & $\begin{array}{l}\text {-Growth defect and defective glycosylation in high } \mathrm{Ca}^{2+} \\
\text { concentration which are supressed by } \mathrm{Mn}^{2+} \text { administration. } \\
\text {-Gdt1p controls cellular calcium stores and respond to osmotic shock. }\end{array}$ & {$[30,141,142]$} \\
\hline & & HEK293 cell line & $\begin{array}{l}\text { TMEM165 knockout by } \\
\text { CRISPR }\end{array}$ & -TMEM165 degradation in lysosomes upon $\mathrm{Mn}^{2+}$ exposure. & [36] \\
\hline & & HEK293 cell line & $\begin{array}{l}\text { TMEM165 knockdown by } \\
\text { shRNA }\end{array}$ & $\begin{array}{l}\text {-Impaired Golgi } \mathrm{Mn}^{2+} \text { homeostasis. } \\
-\mathrm{Mn}^{2+} \text { rescues impaired Golgi glycosylation. }\end{array}$ & [142] \\
\hline & & HeLa cell line & $\begin{array}{l}\text { TMEM165 knockdown by } \\
\text { shRNA }\end{array}$ & -Impaired Golgi $\mathrm{Mn}^{2+}$ homeostasis. & [142] \\
\hline \multirow{3}{*}{$\begin{array}{l}\text { Multiple and other } \\
\text { glycosylation } \\
\text { pathways }\end{array}$} & $\begin{array}{l}\text { TMEM165-CDG/Transmembrane } \\
\text { protein } 165\end{array}$ & Zebrafish & $\begin{array}{l}\text { Homozygous null tmem165 } \\
(\text { tmem165- }\end{array}$ & $\begin{array}{l}\text {-Dysfunctional } N \text {-glycosylation, reduced osteoblast differentiation } \\
\text { and altered craniofacial cartilage development due to defects in } \\
\text { chondrocyte maturation. }\end{array}$ & [143] \\
\hline & \multirow{2}{*}{$\begin{array}{l}\text { TMEM199-CDG/Transmembrane } \\
\text { protein } 199\end{array}$} & S. cerevisiae & $\begin{array}{l}\text { DJY62/DJY102 } \\
\text { (pep4-3 vma12 }:: \text { LEU2) } \\
\text { DJY63 (vma12 } \Delta:: \text { LEU2) }\end{array}$ & -Decreased stability of 100-kDa $\mathrm{V}_{0}$ subunit (Vph1p) of V-ATPase. & {$[105,144]$} \\
\hline & & HeLa cell line & $\begin{array}{l}\text { TMEM199 knockdown by } \\
\text { CRISPR/Cas9 }\end{array}$ & -Lethality after three weeks and accumulation of $\operatorname{HIF} 1 \alpha$. & [106] \\
\hline
\end{tabular}


Table 1. Cont

\begin{tabular}{|c|c|c|c|c|c|}
\hline Defect & CDG/Protein & Cell/Organism/Animal & Model & Major Findings/Phenotype & Reference \\
\hline \multirow{5}{*}{$\begin{array}{l}\text { Lipid glycosylation } \\
\text { and } \\
\text { glycosylphosphatidyl } \\
\text { inositol (GPI) } \\
\text { synthesis }\end{array}$} & \multirow{3}{*}{$\begin{array}{l}\text { PIGA-CDG/Phosphatidylinositol } \\
\text { N-acetylglucosaminyl-transferase } \\
\text { (subunit A) }\end{array}$} & iPSC & $\begin{array}{l}\text { (a) Hypomorphic } \\
\text { (PIGAc.1234C }>\text { T) } \\
\text { (b) PIGA null }\end{array}$ & $\begin{array}{l}\text { (a) Permissive for hematopoiesis with neuronal proliferation, } \\
\text { differentiation, maturation and presynaptic defects. } \\
\text { (b) Non-permissive for hematopoiesis and differentiation. }\end{array}$ & [145] \\
\hline & & Mouse & Piga-deficient chimeric mice & -Chimeric surface expression of GPI-anchored proteins. & [146] \\
\hline & & Mouse & $\begin{array}{l}\text { Partial exon } 2 \text { excision } \\
\text { mediated by loxP }\end{array}$ & $\begin{array}{l}\text {-Viable mosaic mice with lack of GPI-linked proteins on a proportion } \\
\text { of circulating blood cells. } \\
\text {-Increased sensitivity toward complement mediated lysis and a } \\
\text { decreased life span in circulation. }\end{array}$ & [147] \\
\hline & $\begin{array}{l}\text { PIGM-CDG/GPI } \alpha-1,4- \\
\text { mannosyltransferase I }\end{array}$ & Ramos517 cell line & PIGM-deficient & $\begin{array}{l}\text {-Cloning of human homologues PfPIG-M (Plasmodium falciparum) } \\
\text { and GPI14 (S. cerevisiae) but only PfPIG-M restored cell-surface } \\
\text { expression of GPI proteins. }\end{array}$ & [148] \\
\hline & $\begin{array}{l}\text { PIGM-CDG/GPI } \alpha-1,4- \\
\text { mannosyltransferase I }\end{array}$ & S. cerevisiae & $\begin{array}{l}\text { Gpi14 (PIGM homolog) } \\
\text {-deficient }\end{array}$ & $\begin{array}{l}\text {-Glucosaminyl(acyl)phosphatidylinositol accumulation. } \\
\text {-Growth lethality. }\end{array}$ & [149] \\
\hline \multirow{2}{*}{$\begin{array}{l}\text { Lipid glycosylation } \\
\text { and GPI synthesis }\end{array}$} & \multirow{2}{*}{$\begin{array}{l}\text { PIGO-CDG/GPI ethanolamine phosphate } \\
\text { transferase } 3\end{array}$} & CHO cell line & PIGO-deficient cells & -Impaired levels of CD59 and urokinase receptor (uPAR). & {$[35,37]$} \\
\hline & & HEK293 cell line & $\begin{array}{l}\text { PIGO knockout using } \\
\text { CRISPR/Cas9 }\end{array}$ & -Impaired GPI-AP expression. & [35] \\
\hline \multirow{3}{*}{$\begin{array}{l}O \text {-mannosyl-glycan } \\
\text { synthesis }\end{array}$} & \multirow{3}{*}{$\begin{array}{l}\text { ISPD-CDG/2-C-methyl-d-erythritol } \\
\text { 4-phosphate cytidylyltransferase }\end{array}$} & HEK293 cell line & $\begin{array}{l}\text { Ispd knockout using } \\
\text { CRISPR/Cas9 }\end{array}$ & $\begin{array}{l}\text {-Reduced } \alpha \text {-DG glycosylation. } \\
\text {-ISPD synthesize CDP-ribitol required for } \alpha \text {-DG glycosylation. }\end{array}$ & [68] \\
\hline & & HAP1 cell line & $\begin{array}{l}\text { Ispd-disrupted cells by a } \\
\text { CRISPR/Cas9 deletion } \\
\text { causing a frameshift }\end{array}$ & -Supplementation with CDP-Rbo restored $\alpha$-DG glycosylation. & [150] \\
\hline & & Mouse & Homozygous Ispd $\mathrm{L}^{\mathrm{L} 9^{*} / \mathrm{L} 79^{*}}$ & $\begin{array}{l}\text {-No embryonic lethality, but did not survived beyond birth due to } \\
\text { apparent respiratory failure. } \\
\text {-Normal total dystroglycan protein levels, but severely reduced } \\
\text { levels of } \alpha \text {-DG and laminin binding activity in brain extracts. } \\
\text {-Lose of dystroglycan glycosylation in cortex extracts. }\end{array}$ & [151] \\
\hline \multirow{2}{*}{$\begin{array}{l}O \text {-mannosyl-glycan } \\
\text { synthesis }\end{array}$} & \multirow{2}{*}{$\begin{array}{l}\text { ISPD-CDG /2-C-methyl-d-erythritol } \\
\text { 4-phosphate cytidylyltransferase }\end{array}$} & Mouse & $\begin{array}{l}\text { Ispd conditional knockout } \\
\text { using Cas9 nickase (Cas9n) } \\
\text { and a single guide RNA } \\
\text { (sgRNA) }\end{array}$ & -No phenotype available. & [152] \\
\hline & & Zebrafish & Ispd knock-out & $\begin{array}{l}\text {-Incomplete brain folding in the majority of the embryos as well as } \\
\text { hydrocephalus, reduced eye size, muscle fiber degeneration and } \\
\text { impaired motility. } \\
\text {-Protein hypoglycosylation, especially for } \alpha \text {-DG. }\end{array}$ & [153] \\
\hline
\end{tabular}




\section{Biomarkers}

Biomarkers are essential for diagnostics, assessment of disease progression and ultimately quantification of the effect of therapeutic approaches. Transferrin glycosylation has been the main biomarker for CDG screening and therapy monitoring. The analysis of its $\mathrm{N}$-glycosylation profile by different techniques (reviewed in [4]) is widely used. Nevertheless, the existence of CDG with normal transferrin glycosylation, the normalization of glycosylation patterns with age in several CDG and charge altering transferrin variants, stress the need for complementary biomarkers $[154,155]$. Currently, clinical CDG screening for $\mathrm{N}$-glycosylation disorders relies mainly on isoelectric focusing (IEF) of serum transferrin (TF) and $\alpha_{1}$-antitrypsin, whereas for some $O$-glycosylation disorders it relies on apolipoprotein C-III (apoC-III) IEF (Table 2) [7,155-157]. N-glycan profile analysis by mass spectrometry (MS) is also used for CDG types for which transferrin profile analysis cannot be used. Plasma glycosylation features from $\mathrm{N}$-glycans and intact transferrin used for CDG diagnostics are reviewed in Bakar et al. [8].

Besides these markers used for diagnosis, others have been described in the literature in research or clinical context and are collected in Table 3.

\section{Dietary Supplementation Therapies}

Various inherited metabolic disorders (IMDs) respond to dietary supplementation and/or restriction strategies $[158,159]$. In this section, we analyze the effects of supplementation with sugars (e.g., mannose, galactose, fucose), nucleotides (e.g., uridine) and trace elements (e.g., manganese, magnesium) in CDG.

\subsection{Defects Located in the Cytosol}

\subsubsection{Defects in Protein N-Glycosylation}

\section{MPI-CDG}

MPI-CDG (MIM: 602579) is a disorder of the mannose metabolism due to deficient function of the enzyme mannose-6-phosphate isomerase (MPI, EC 5.3.1.8), responsible for the interconversion of fructose-6-P (Fru-6-P) and mannnose-6-P (Man-6-P) [91]. Man supplementation was first tried in a patient in 1998 [49]. Remarkable biochemical and clinical improvement has been registered in treated MPI-CDG patients, including disappearance of hypoglycemia and gastrointestinal manifestations, normalization of coagulation, improvement of transferrin glycosylation profile, and normal growth (Figure 1). At least 12 MPI-CDG patients have been successfully treated with Man [49,160-169], however, Man therapy can show side effects that have caused therapy discontinuation in a few patients $[165,170]$. It also fails to correct overall glycosylation profile [162] and treat hepatic disease [168,171]. This can be due to the liver's distinct Man requirements [172], or to mannose inability to correct liver disease progression [92,168]. In animal models, contradictory effects of Man supplementation, have been reported regarding embryonic lethality [72,91,92]. These reports sparked the discussion on the possible dangers associated with pre-natal therapy, and on the most effective moment/age to initiate treatment. It also highlighted possible negative long-term effects of continued sugar supplementation. Difference in therapy responses may be explained by disease heterogeneity and severity, route of Man administration (e.g., IV vs. oral), genetic background, and/or age of treatment initiation $[162,165,170,173]$.

Interestingly, high plasma aspartylglucosaminidase (AGA) activity and reduced intercellular adhesion molecule 1 (ICAM-1) expression have been suggested as biomarkers of CDG-I, including MPI-CDG in which AGA and ICAM-1 levels normalized after Man treatment [166,174]. Moreover, Man-mediated elevation of ICAM-1 has been connected to an enhanced immune response in the mouse model [175].

Man is an approved dietary supplement in the treatment of MPI-CDG in both Europe and the USA. 
Table 2. Overview of diagnosis biomarkers reported for CDG.

\begin{tabular}{|c|c|c|c|c|c|}
\hline CDG/Protein & Biomarker & Sample * & Major Findings & Detection Technique & Reference \\
\hline CDG-I/CDG-II & Transferrin & Serum/plasma & Altered glycosylation pattern & $\begin{array}{c}\text { IEF, high performance liquid } \\
\text { chromatography (HPLC), capilary zone } \\
\text { electrophoresis (CZE) }\end{array}$ & {$[7,156]$} \\
\hline CDG-I/CDG-II & $\alpha_{1}$-antitrypsin & Serum/plasma & Altered glycosylation pattern & $\begin{array}{l}\text { 2-Dimensional difference gel } \\
\text { electrophoresis (2D DIGE), IEF }\end{array}$ & [156] \\
\hline CDG-II & Lipoprotein ApoCIII & Serum/plasma & $\begin{array}{l}\text { Altered profile of the three protein } \\
\text { isoforms: apoCIII }{ }_{0} \text {, apoCIII }{ }_{1} \text { and } \\
\text { apoCIII }{ }_{2} \text { (hypoglycosylation) }\end{array}$ & IEF & {$[4,7,157]$} \\
\hline ALG1-CDG/ $\beta$-1,4-mannosyl-transferase & $\begin{array}{c}\text { Tetrasaccharide } \\
\text { (NeuAc-Gal-GlcNAc2) }\end{array}$ & Serum/plasma TF & Increased levels & $\begin{array}{l}\text { Liquid chromatography-mass } \\
\text { spectrometry (LC/MS) and enzymatic } \\
\text { digestions }\end{array}$ & {$[34,176]$} \\
\hline ALG6-CDG/Glucosyl-Transferase & $\mathrm{Man}_{9} \mathrm{GlcNAc}_{2}$-P-P-dolichol & Fibroblasts & Increased levels & $\begin{array}{l}\left.\text { 2- }{ }^{3} \mathrm{H}\right] \text { mannose labeling and HPLC } \\
\text { analysis }\end{array}$ & [177] \\
\hline $\begin{array}{l}\text { ALG1-CDG/ } \beta \text {-1,4-mannosyl-transferase, } \\
\text { MPI-CDG/Phospho-mannose isomerase, } \\
\text { PMM2-CDG/Phosphomannomutase } 2\end{array}$ & $\begin{array}{c}N \text {-tetrasaccharide } \\
\left(\mathrm{Neu}_{5} \mathrm{Ac} \_2,6 \mathrm{Gal} \_1,4-\mathrm{GlcNAc} \_1,4 \mathrm{GlcNAc}\right)\end{array}$ & $\begin{array}{l}\text { Sera, plasma and } \\
\text { fibroblasts }\end{array}$ & Increased levels compared to control & $\begin{array}{c}\text { LC-MS/MS } \\
\text { Matrix assisted laser } \\
\text { desorption/ionization-time of flight-mass } \\
\text { spectrometry (MALDI-TOF-MS) }\end{array}$ & [178] \\
\hline
\end{tabular}

* Unless otherwise specified, the samples are derived from patients.

Table 3. Overview of other biomarkers reported for CDG.

\begin{tabular}{|c|c|c|c|c|c|}
\hline CDG/Protein & Biomarker & Sample * & Major Findings & Detection Technique & Reference \\
\hline CDG-I & Glyc-ER-GFP & Fibroblasts and iPSCs & Fluorescence & Flow Cytometry & [179] \\
\hline CDG-I & Thyroxine binding globulin & Serum & Abnormal glycosylation & IEF & [180] \\
\hline CDG-II & Glyc-ER-GFP & Fibroblasts & No fluorescence & Flow Cytometry & [179] \\
\hline CDG-II & $\begin{array}{l}\text { (a) } \alpha_{1} \text {-acid glycoprotein } \\
\text { (b) Ceruloplasmin }\end{array}$ & Serum & $\begin{array}{l}\text { (a) Extra isoform with higher pI value } \\
\text { (b) Subtle pI change }\end{array}$ & 2D DIGE & [155] \\
\hline \multirow{3}{*}{$\begin{array}{l}\text { GNE-CDG/UDP-GlcNAc } \\
\text { 2-epimerase/ManNAc kinase }\end{array}$} & GM3 and GD3 gangliosides & $\begin{array}{l}\text { Human embryonic kidney } \\
\text { (HEK AD293) cells } \\
\text { Muscle of Gne } \mathrm{e}^{\mathrm{M} 712 \mathrm{~T} / \mathrm{M} 712 \mathrm{~T}} \text { mouse model }\end{array}$ & Increased levels & $\begin{array}{l}\text { Flow cytometry } \\
\text { HPLC }\end{array}$ & {$[181,182]$} \\
\hline & NCAM & $\begin{array}{l}\text { Brain solubilisates from heterozygous } \\
\text { GNE-deficient mice } \\
\text { Serum obtained from patients and } \\
\text { Gne }{ }^{\mathrm{M} 712 \mathrm{~T} / \mathrm{M} 712 \mathrm{~T}} \text { mouse }\end{array}$ & Hypolysialylated & WB & {$[116,183]$} \\
\hline & Thomsen-Friedenreich ( $\mathrm{T}$ )-antigen & Plasma & $\begin{array}{l}\text { Increased ratio of T-antigen } \\
\text { (Gal-GalNAc-) to ST (sialylated)- antigen } \\
\text { (core 1 SA-Gal-GalNAc-) }\end{array}$ & MS & [184] \\
\hline
\end{tabular}


Table 3. Cont

\begin{tabular}{|c|c|c|c|c|c|}
\hline CDG/Protein & Biomarker & Sample* & Major Findings & Detection Technique & Reference \\
\hline \multirow[b]{2}{*}{ PMM2-CDG/Phosphomannomutase 2} & Band 3 and glycophorin $\mathrm{A}$ & Erythrocytes & Underglycosylated & SDS-PAGE & [185] \\
\hline & $\begin{array}{l}\text { Glycosphingolipids } \\
\text { (Gb3, GM2, GD3 and GD1a) }\end{array}$ & Fibroblasts & Increased levels compared to control & $\begin{array}{l}\text { Radiolabeling followed by } \\
\text { HPTLC }\end{array}$ & [186] \\
\hline \multirow[t]{2}{*}{ PMM2-CDG/Phosphomannomutase 2} & $\begin{array}{l}\text { (a) } \alpha_{1} \text {-acid glycoprotein } \\
\text { (b) Ceruloplasmin } \\
\text { (c) } \alpha_{1} \text {-antichymotrypsin } \\
\text { (d) } \alpha_{1} \text { B-glycoprotein } \\
\text { (e) Haptoglobin }\end{array}$ & Serum & $\begin{array}{l}\text { (a) Lower MW isoform } \\
\text { (b) Profound pI change } \\
\text { (c) Abnormal profile } \\
\text { (d) Abnormal profile } \\
\text { (e) Absence of stainable protein }\end{array}$ & 2D DIGE & {$[155,187]$} \\
\hline & $\mathrm{TSH}$ and $\mathrm{TF}_{4}$ & Serum & Increased TSH and decreased $\mathrm{TF}_{4}$ levels & Immune-based method & {$[4,188]$} \\
\hline $\begin{array}{c}\text { ALG6-CDG/Glucosyl-Transferase, } \\
\text { PMM2-CDG/Phosphomannomutase } 2\end{array}$ & $\beta$-trace protein & Cerebrospinal fluid & Abnormal glycosylation profile & $\begin{array}{l}\text { SDS-PAGE and } \\
\text { immunoblotting }\end{array}$ & {$[180,189]$} \\
\hline $\begin{array}{l}\text { ALG6-CDG/Glucosyl-Transferase, } \\
\text { MPI-CDG/Phospho-mannose isomerase, } \\
\text { PMM2-CDG/Phosphomannomutase 2 }\end{array}$ & $\begin{array}{l}\text { Aspartylglucosaminidase } \\
\text { (AGA) }\end{array}$ & Plasma & Increased levels & Enzymatic activity & [166] \\
\hline $\begin{array}{l}\text { ALG13-CDG/UDP-GlcNAc transferase, } \\
\text { MPI-CDG/Phospho-mannose isomerase, } \\
\text { PMM2-CDG/Phosphomannomutase } 2\end{array}$ & ICAM-1 & $\begin{array}{l}\text { (a) Lec9 } \mathrm{CHO} \text { cells and fibroblasts } \\
\text { (b) Mesenteric endothelial } \\
\text { cells of } \mathrm{Mpi}^{-/-} \text {mouse }\end{array}$ & Decreased levels & $\begin{array}{l}\text { (a) LC-MS/MS } \\
\text { SDS-PAGE and WB } \\
\text { IF staining } \\
\text { Flow Cytometry } \\
\text { (b) Immuno- } \\
\text { histochemistry }\end{array}$ & {$[174,175,190]$} \\
\hline
\end{tabular}

* Unless otherwise specified, the samples are derived from patients. Glyc-ER-GFP-N-glycosylated-endoplasmic reticulum targeted-green fluorescent protein, TF-Transferrin, CZE—capilary zone electrophoresis, LC-MS/MS - Liquid chromatography—tandem mass spectrometry, MALDI-TOF-MS-Matrix assisted laser desorption/ionization-time of flight-mass spectrometry, HPLC_High performance liquid chromatography, SDS-PAGE-Sodium odecyl sulfate polyacrylamide gel electrophoresis, Gb3—globotrihexosylceramide, GM2-Ganglioside monosialic 2, GD3-Ganglioside disialic 3, GD1a-Ganglioside disialic 1a, HPTLC—High-performance thin-layer chromatography, VCAM-Neural cell adhesion molecule, IEF-Isoelectric focusing, GM3-Ganglioside monosialic 3, ICAM-Intercellular cell adhesion molecule, , WB-Western blotting, IF-Immunofluorescence, 2D DIGE-2-Dimensional difference gel electrophoresis, MW-Molecular weight, $\mathrm{pI}$-Isoelectric point, AT-III—antithrombin III, TSH—Thyroid stimulating hormone, TF 4 -Thyroxine. 


\section{PMM2-CDG}

PMM2-CDG (MIM: 212065) results from mutations in the gene encoding phosphomannomutase 2 (PMM2, EC 5.4.2.8), an enzyme that converts Man-6-P to mannose-1-phosphate (Man-1-P) in the cytoplasm. Phosphomannomutase 1 (PMM1) is a paralogous enzyme whose role, if any, in PMM2-CDG pathology has not been elucidated yet [191-193]. Prior to the identification of the underlying molecular cause of PMM2-CDG, Panneerselvam and Freeze had shown that the hypoglycosylation phenotype in PMM2-CDG patient fibroblasts could be resolved by the addition of Man to the culture medium [46]. This has been replicated by other in vitro $[47,52,194]$ and in vivo models [77] (Figure 1).

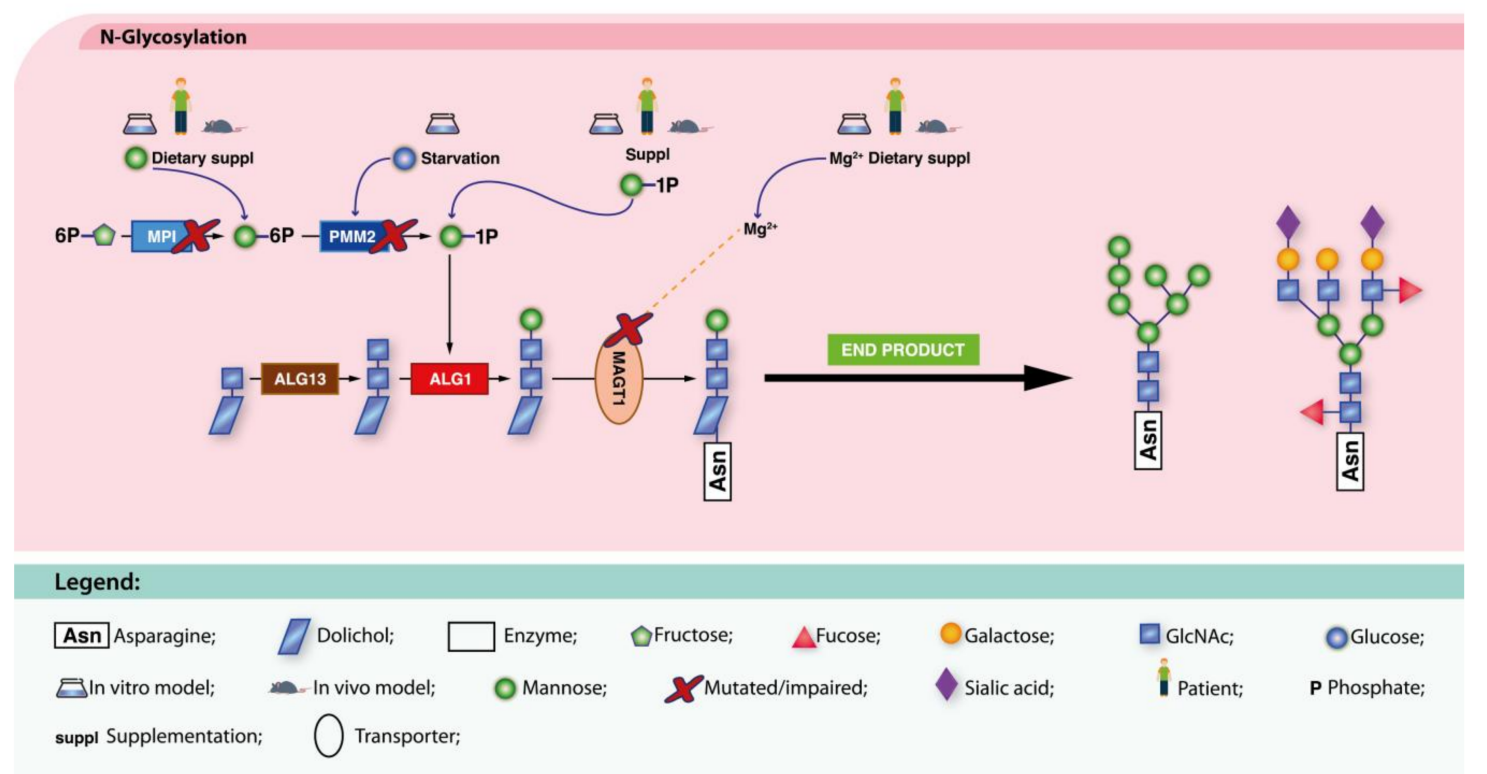

Figure 1. Dietary supplementation approaches under investigation for ALG1-CDG, MPI-CDG, PMM2-CDG and MAGT1-CDG. For MPI-CDG and PMM-CDG, exogenous Man or Man-1-P respectively, is administered (blue arrows). For PMM2-CDG, glucose starvation (blue arrow) was also studied. For ALG1-CDG, Man-1-P supplementation (black arrow) might also represent a promising approach. $\mathrm{Mg}^{2+}$ supplementation (blue arrow) is used to correct MAGT1 transporter defect (dotted yellow line). These therapeutic approaches aim to recover the metabolic pathways (black arrows) and ultimately, the normal glycosylation profile (bold black arrow).

In PMM2-CDG patients, Man appeared to be well-absorbed, increasing the blood levels of this sugar without any associated renal and/or hepatic toxicity $[195,196]$. Nonetheless no clinical or biochemical improvement was observed in these patients [196-198]. Despite this absence of glycosylation correction, some parents have reported improved psychomotor function in their children [199].

It has been postulated that PMM2-CDG cells have a reduced guanosine diphosphate (GDP)-Man pool, and that exogenous Man restores that depletion, hence, correcting the underglycosylation defect of these cells [52]. The direct correlation between phenotypic severity and protein truncation, manifested by lower mannose peak concentrations, suggests that the effectiveness of exogenous Man supplementation is influenced by PMM2 residual activity $[59,198,199]$. However, the presence of alternative transport systems cannot be excluded. Interestingly, it has been reported that metformin can induce and increase Man uptake by PMM2-deficient cells, by the activation of a Man-selective transport system, which corrects $N$-glycosylation in these cells [200].

To stimulate and solve uptake issues, maximizing retention and incorporation of Man, some alternative methods have been developed, including the synthesis of membrane permeable, hydrophobic Man-1-P-based prodrugs [201-203]. This could potentially improve stability, 
dissemination, assimilation, and therapeutic action of Man derivatives. In fact, hydrophobic Man-1-P compounds have corrected glycosylation in vitro [202].

The most recent strategy for Man supplementation is currently under development by Glycomine, which is developing a Man-1-P pharmacological formulation using liposomes as the delivery system [204].

\subsubsection{Defects in Monosacharide/Nucleotide Synthesis}

\section{CAD-CDG}

Uridine monophosphate synthase (UMPS)-deficiency (hereditary orotic aciduria, MIM: 258900) is a rare inborn error of metabolism (IEM) resulting in abnormal pyrimidine synthesis and uridine supplementation has shown positive clinical results in these patients [205]. CAD encodes a multifunctional enzyme complex (comprising amidophosphoribosyltransferase, EC 2.4.2.14; carbamoyl-phosphate synthase, EC 6.3.5.5; aspartate carbamoyltransferase, EC 2.1.3.2 and dihydroorotase EC 3.5.2.3) that catalyzes the first steps of de novo pyrimidine biosynthesis (Figure 2). Mutations in this gene have recently been associated with CDG (MIM: 616457) [69,100].

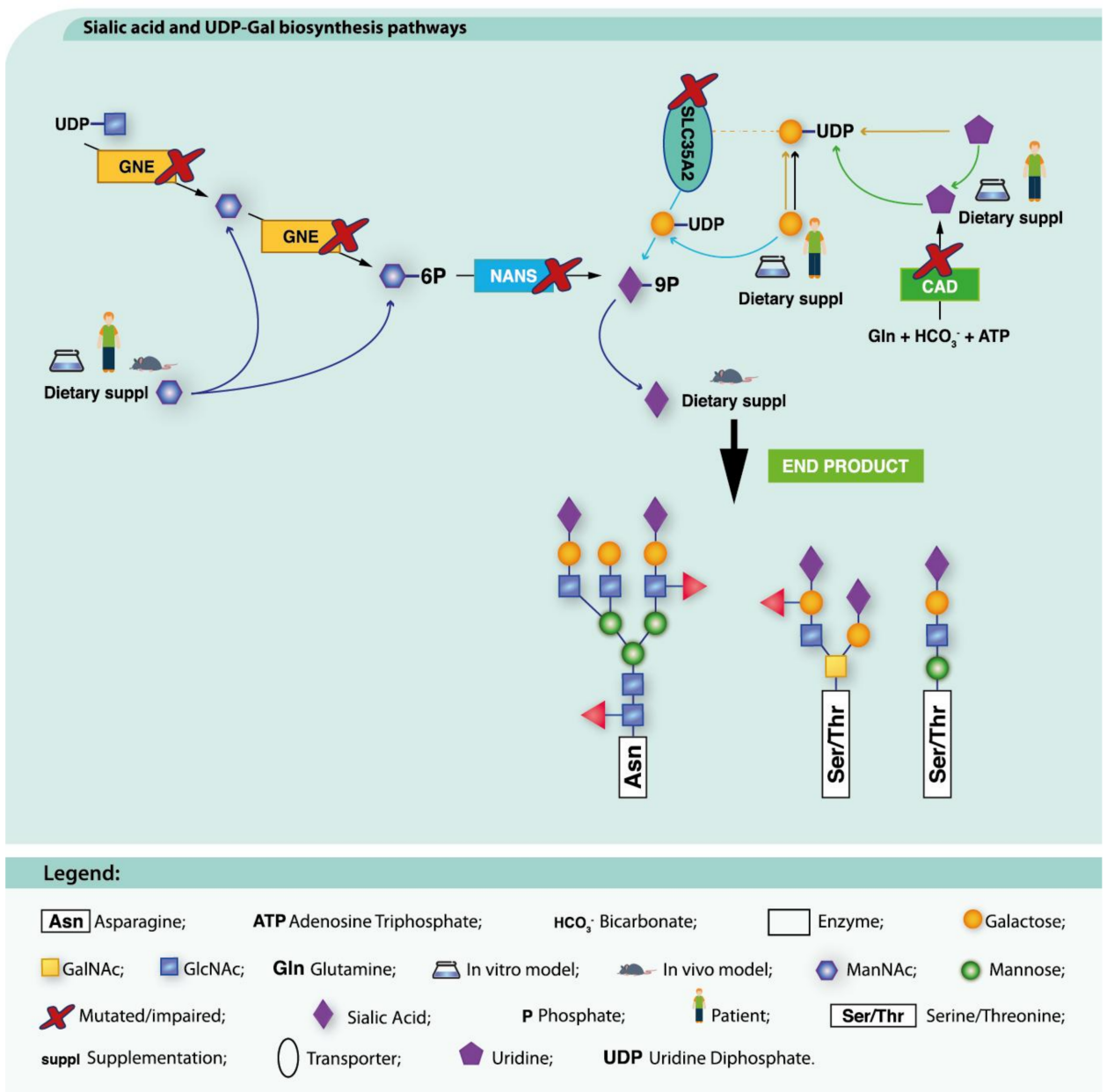

Figure 2. Dietary supplementation approaches under investigation for CAD-CDG, GNE-CDG, NANS-CDG and SLC35A2-CDG. Uridine supplementation has been tried for CAD-CDG (green arrow). Combined administration of uridine and Gal aims to increase Gal-UPD levels (yellow, green, black and light blue arrows). This allows the bypass of SLC35A2 transporter defect. ManNAc supplementation (dark blue arrow) has been used for GNE-CDG and NANS-CDG. These therapeutic approaches aim to recover the metabolic pathways (black arrows) and ultimately, the normal glycosylation profile (bold black arrow). 
Based on this molecular knowledge and on previous findings obtained from in vitro CAD models, in which the decreased pools of nucleotide sugars (UDP-GlcNAc, UDP-GalNAc, UDP-Glc, UDP-Gal) and other metabolites that serve as glycosylation donors were normalized by uridine supplementation to the culture medium [100], Koch et al. treated two severely affected CAD-CDG patients with $100 \mathrm{mg} / \mathrm{kg}$ per day oral uridine in a daily regimen of 4 doses. This led to a dramatic clinical improvement, including seizure cessation, cognitive and motor development, increased alertness and communication as well as normalization of biochemical parameters [69].

\section{GNE-CDG}

GNE-CDG (MIM: 605820) is caused by defects in UDP- $N$-acetylglucosamine 2-epimerase (UDP-GlcNAc 2-epimerase, EC 5.1.3.14)/ $N$-acetylmannosamine kinase (ManNAc kinase, EC 2.7.1.60), a bifunctional and rate-limiting enzyme of SA biosynthesis. Evidence that supplementation of SA precursors, such as the aminosugars ManNAc or D-mannosamine (ManN), can bypass GNE defects has been obtained in a set of different disease models (Figure 2) $[19,74,78,81,109,110,206,207]$. ManNAc treatment restored glycosphingolipid (GSL) levels in patient cells [66] and up-regulated Gne and protein expression, therefore suggesting that this aminosugar may act as a protein stabilizer [80,81]. As many GNE-CDG patients are likely to be diagnosed only in adulthood, the effects of oral ManNAc, SA or ManN therapy in adult mutant mice were tested, demonstrating that all of these compounds rescued kidney and muscle hyposialylation [78]. However, only ManNAc improved proteinuria $[78,117]$.

Due to rapid degradation, clearance and, hence, low incorporation of the aminosugars, $\mathrm{Ac}_{4}$ ManNAc and SA were also evaluated in vitro and in vivo with $\mathrm{Ac}_{4}$ ManNAc showing the best results [82,83,207]. 6'-sialyllactose has also been administered to GNE-CDG mice. This compound is slowly metabolized which increases its blood half-life and cellular incorporation. It significantly ameliorated muscle functioning, strength and sialylation [82,84]. These preclinical results have been the basis for several clinical trials (see Table 3).

\section{NANS-CDG}

NANS-CDG (MIM: 610442) results from defects in the CMP-N-acetylneuraminic acid synthetase (EC 2.7.7.43), an enzyme involved in the SA biosynthetic pathway (Figure 2). In a zebrafish model, addition of SA to the water following morpholino injection led to a partial recovery of skeletal anomalies, but only when added $24 \mathrm{~h}$ post-fertilization [122]. These preliminary results should encourage the setting up of clinical trials, provided that further molecular, pharmacokinetics and pharmacodynamics data are gathered. However, they also raise the possibility of (in)effectiveness of post-natal therapy. A first-in-human trial using a slow release form of SA supplementation in NANS-CDG patients has been submitted for approval; however based on the negative results of SA therapy in GNE-CDG (Table 3), the slow release form of SA is currently not available for therapeutic trials.

\section{PGM1-CDG}

PGM1-CDG (MIM: 614921) is a disease affecting phosphoglucomutase 1 (PGM1, EC 5.4.2.2). PGM1 catalyzes the conversion of glucose-1-phosphate (Glc-1-P) to glucose-6-phosphate (Glc-6-P) and is a key enzyme for glycogen, glucose and galactose metabolism and glycosylation. Gal supplementation has restored $N$-glycosylation in vitro $[65,208]$ and oral Gal consumption is safe and associated with significant improvement of $\mathrm{N}$-glycosylation and clinical parameters (liver, coagulation and hormonal function) in PGM1-CDG patients $[65,208,209]$ (Figure 2).

Combined Gal and uridine (as a source of UDP-Gal, Figure 3) therapy has been attempted, with promising results in vitro [65]. Nevertheless, other symptoms, such as dilated cardiomyopathy (DC), are not corrected by Gal or its combination with uridine [209,210].

Exercise intolerance with episodes of rhabdomyolysis and hypoglycemia has also been associated with PGM1 deficiency and Gal and glucose administration has improved exercise tolerance [211,212]. 


\section{PGM3-CDG}

PGM3-CDG is due to defects in the phosphoglucomutase 3 (PGM3, EC 5.4.2.2) enzyme that catalyzes the interconversion of $N$-acetylgalactosamine-1-phosphate (GlcNAc-1-P) and $\mathrm{N}$-acetylgalactosamine-6-phosphate (GlcNAc-6-P) [213]. PGM3 defects cause a form of immunodeficiency (MIM: 615816), partially responsive to antimicrobial prophylaxis, but not to immunoglobulin replacement. PGM3 mutations disrupt the synthesis of UDP-GlcNAc (an $\mathrm{N}$-glycan, $\mathrm{O}$-glycan, proteoglycan and GPI-anchored protein building block). Concordantly, GlcNAc supplementation to patients' cells restored depleted UDP-GlcNAc, thus creating a therapeutic avenue for PGM3-CDG patients (Figure 3) [67]. Unfortunately, the therapeutic trial was unsuccessful, and the clinical trial for this approach was recently closed.

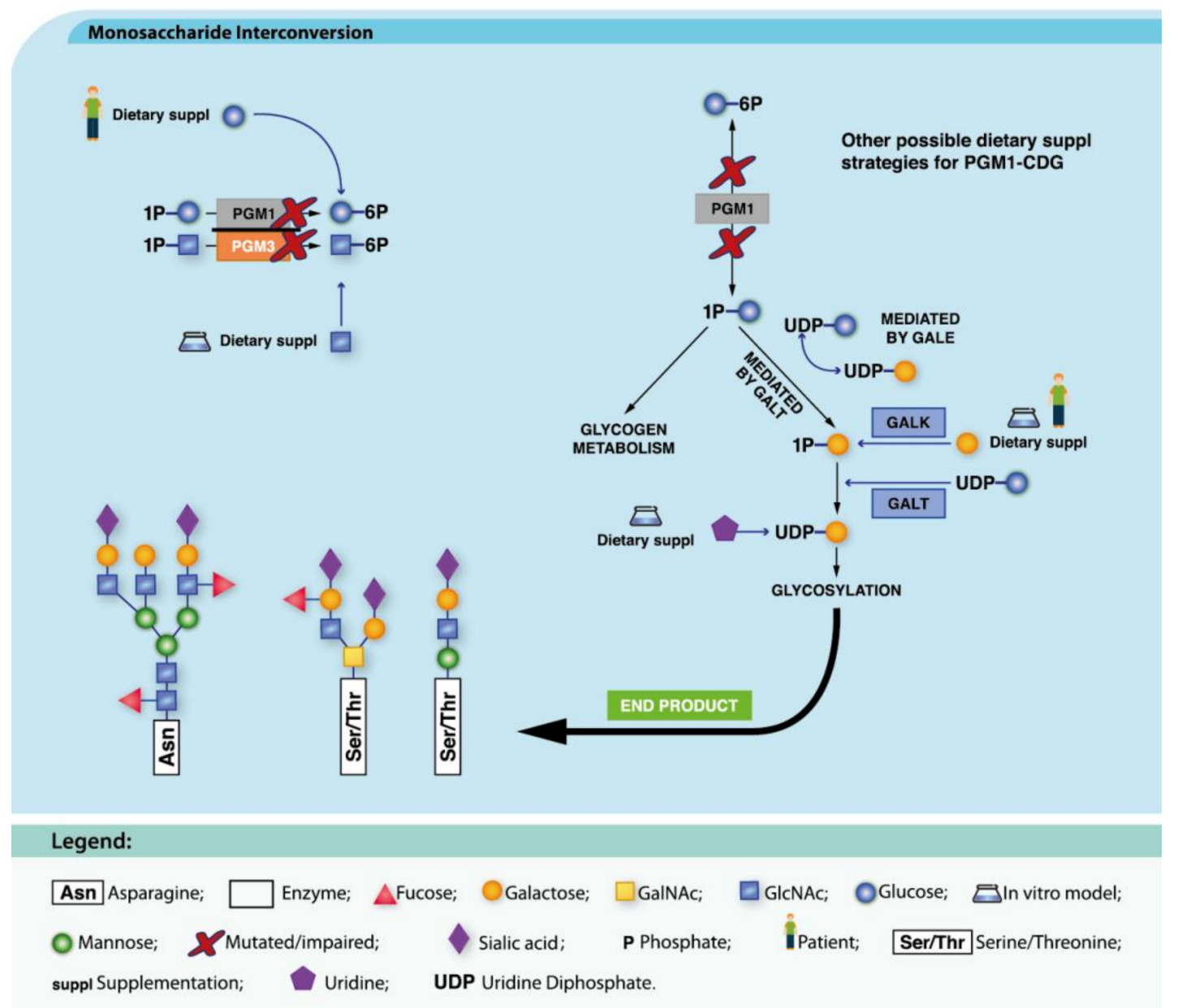

Figure 3. Dietary supplementation approaches under investigation for PGM1-CDG and PGM3-CDG. GlcNAc supplementation has been tried in vitro for PGM3-CDG (blue arrow) while for PGM1-CDG, Glc, uridine and Gal (blue arrows) have been tried. These therapeutic approaches aim to recover the metabolic pathways (black arrows) and ultimately, the normal glycosylation profile (bold black arrow).

\subsection{Defects Located in the Endoplasmic Reticulum (ER)}

\subsubsection{Defects in Protein N-Glycosylation}

\section{ALG1-CDG}

ALG1-CDG (MIM: 608540) is caused by defective LLOs mannosylation. The ALG1 gene encodes the chitobiosyldiphosphodolichol $\beta$-mannosyltransferase (EC 2.4.1.142) which synthetizes 
$\beta-1,4-\mathrm{D}-\mathrm{mannosylchitobiosyldiphosphodolichol.} \mathrm{After} \mathrm{a} 16 \mathrm{~h}$ incubation with $500 \mu \mathrm{mol} / \mathrm{L}$ of Man, ALG1-CDG patient fibroblasts displayed increased levels of high-mannose (Man) and sialylated $\mathrm{N}$-glycans, as well as decreased levels of the $\mathrm{N}$-tetrasaccharide, which was put forward as a disease biomarker [178]. This encouraging data not only reveals the existence of a promising, therapy-sensitive biomarker, but also points out sugar supplementation as a possible therapeutic approach for these patients.

\section{ALG13-CDG}

ALG13-CDG (MIM: 300884) is due to the impairment of $N$-acetylglucosaminyldiphosphodolichol $N$-acetylglucosaminyltransferase (EC 2.4.1.141), encoded by ALG13 which leads to $N$-glycosylation deficiency. In fibroblasts from a patient with a hemizygous missense mutation (p.E463G), D-galactose (Gal) addition to the culture media increased low ICAM-1 levels to almost normal values [190]. This points to ICAM- 1 as a potential disease and therapy informative biomarker, and Gal supplementation as a putative treatment for ALG13-CDG patients.

\section{MAGT1-CDG}

The role of magnesium transporter 1 (MAGT1) as a $\mathrm{Mg}^{2+}$ transporter has been long established [90], but the importance of this protein in $\mathrm{N}$-glycosylation has only been recently unraveled [214]. MAGT1 mutations have been associated with a X-linked immunodeficiency with $\mathrm{Mg}^{2+}$ defect, Epstein-Barr virus (EBV) infection and neoplasia (XMEN syndrome, MIM:300853) [63,215]. In vitro and in vivo $\mathrm{Mg}^{2+}$ supplementation has shown encouraging results $[63,215]$ and a patient has been reported to be on oral $\mathrm{Mg}^{2+}$ therapy (Figure 3). Unfortunately, no patient follow-up has yet been reported.

\subsubsection{Defects in Lipid Glycosylation and GPI Synthesis}

\section{PIGA-CDG}

PIGA encodes the subunit A of the phosphatidylinositol $N$-acetylglucosaminyltransferase enzyme (EC 2.4.1.198). Defects in this catalytic subunit result in the multiple congenital anomalies-hypotonia-seizures syndrome-2 (MCAHS2; MIM: 300868) characterized by brain and other organ affectations [216].

Two brothers with drug-resistant seizures showed great improvement upon initiation of a ketogenic diet, including seizure control and improved development [216]. Ketogenic diet has high fat and low carbohydrate content, therefore making ketone bodies the brain's main source of energy [217]. Ketone bodies stimulate $\gamma$-amino butyric acid (GABA) production and reception, initiating an antiepileptic effect [158].

Ketogenic diets are usually rich in omega- 3 and omega- 6 polyunsaturated fatty acids (PUFAs) [218]. PUFAs have recently been described to have modulatory effects on voltage-gated ion channels (transmembrane proteins essential for heart and brain function), and thus, a potential anti-epileptic effect [218]. One should keep in mind that a ketogenic diet may aggravate/potentiate hypoglycemia in these patients [15].

\section{PIGM-CDG}

PIGM-CDG (MIM: 610293) results from mutations in the promoter region of the PIGM gene. PIGM encodes the catalytic subunit of the GPI $\alpha$-1,4-mannosyltransferase I enzyme and defects in this protein results in deficient addition of the first Man in the GPI core biosynthesis [219]. This disrupts binding of the Sp1 transcription factor, impairs histone acetylation, gene transcription and expression. Almeida et al., described that sodium butyrate induced acetylation, and increased PIGM transcription, both in vitro and in a patient (Figure 4). The patient became seizure-free, and reacquired previously lost 
capabilities [57]. These data suggest that histone deacetylase (HDAC) inhibitors may be an interesting therapeutic approach for this CDG [219].

\section{PIGO-CDG}

PIGO-CDG (MIM: 614749) is a defect in the PIGO gene that encodes the GPI glycan biosynthesis class O (also known as GPI ethanolamine phosphate transferase 3) protein which is involved in GPI-anchor biosynthesis [35]. Defects in PIGO cause hyperphosphatasia and intellectual disability. Similarly to what happens in PIGA-CDG, PIGO-CDG patients suffer from intractable seizures. Oral administration of $400 \mathrm{mg}(20 \mathrm{mg} / \mathrm{kg}$ ) of vitamin B6 (pyridoxine) has rendered a PIGO-CDG patient seizure-free [220]. The therapeutic effect of vitamin B6 intake is likely related to stimulation of brain GABA synthesis, which may be impaired due to lack of pyridoxine [35] (Figure 4).

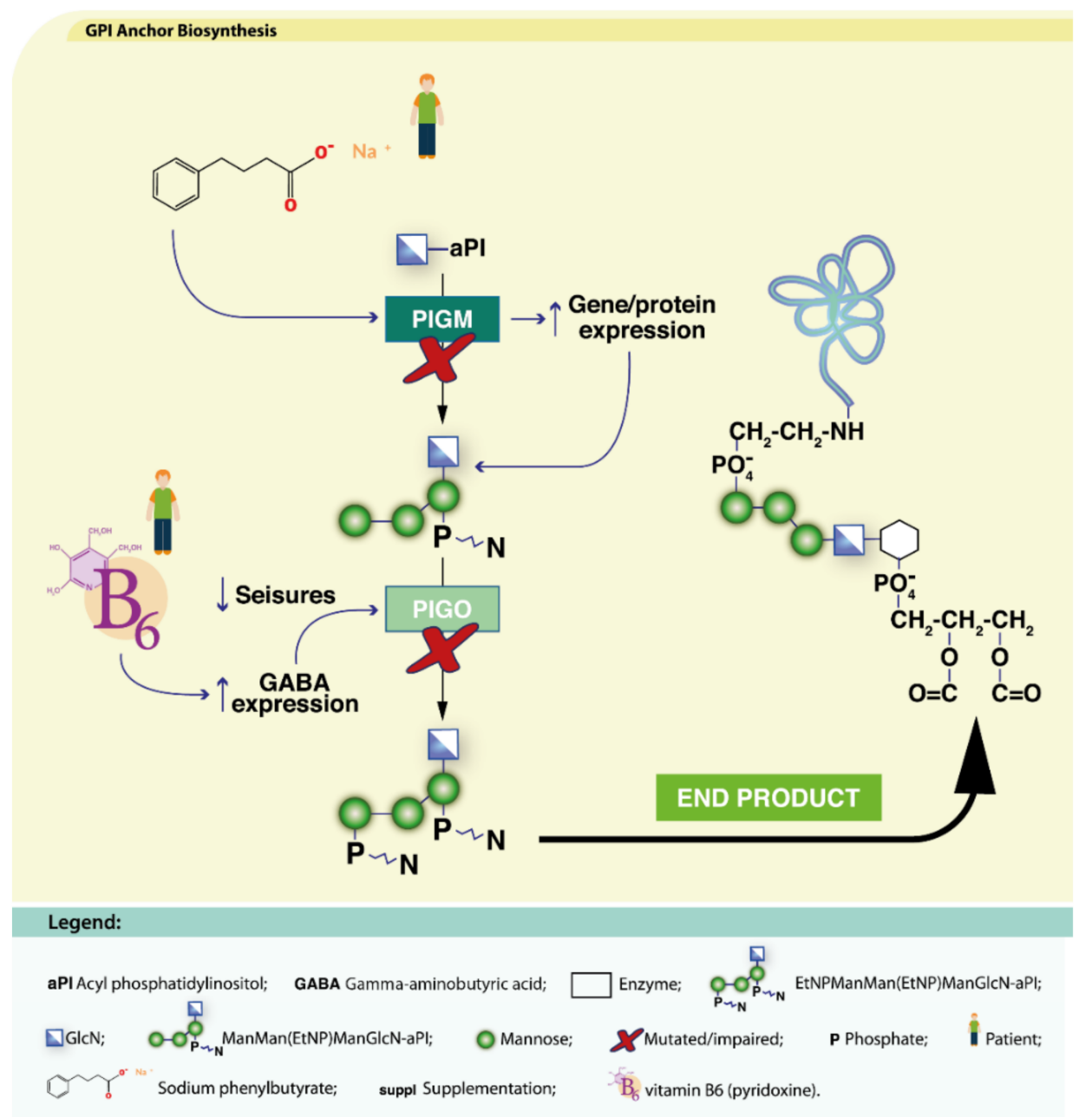

Figure 4. Dietary supplementation approaches under investigation for PIGM-CDG and PIGO-CDG. Vitamin B6 due to its ability to increase GABA expression has been tried for PIGO-CDG (blue arrows). Sodium butirate, which can increase PIGM expression, has been tried for PIGM-CDG (blue arrow). These therapeutic approaches aim to recover the metabolic pathways (black arrows) and ultimately, the final end product (bold black arrow). 


\subsection{Defects Located in the Golgi Apparatus}

\subsubsection{Defects in Nucleotide-Sugar Transporters}

\section{SLC35A1-CDG}

SLC35A1-CDG (MIM: 603585) is caused by defects in the solute carrier family 35 member A1 protein which transports CMP-SA to the Golgi complex. Addition of SA sources, such as SA itself, ManNAc or the glycoprotein fetuin, to the culture media failed to rescue the sialylation deficiency in patient-derived cells [71].

\section{SLC35A2-CDG}

SLC35A2-CDG (MIM: 300896) arises from defective UDP-Gal transportation to the Golgi apparatus by the UDP-Gal translocator (also known as solute carrier family 35 member A2). Gal supplementation $(1 \mathrm{~g} / \mathrm{kg} /$ day $)$ in a patient normalized the transferrin glycosylation profile after 6 months (Figure 2) [33]. Remarkably, in a previous study using patient-derived fibroblasts, Gal addition to the culture media did not achieve any results [221]. This might be partly explained by different experimental conditions and/or by distinct genetic backgrounds.

\section{SLC35C1-CDG}

SLC35C1-CDG (MIM: 266265) is caused by defects in the SLC35C1 which encodes a GDP-fucose transmembrane transporter. This leads to deficient import of GDP-fucose into the Golgi apparatus. Fucose addition to the culture medium corrects fucosylation as well as other biochemical and functional parameters in cells $[23,27,50,51,53]$, and in animal models $[132,136]$. Fucose supplementation produced biochemical and clinical improvement, including normalization of neutrophil counts, re-expression of E- and P-selectin ligands, infection recurrence cessation [23,53,54,222], as well as improved psychomotor development, although to a lesser extent $[23,53,54]$. Divergence in therapy efficacy and effect has also been reported. SLC35C1-CDG patients have the Bombay blood types, as they lack the $\alpha 1$,2-fucosylated $\mathrm{H}$-antigen. Fucose therapy did not result in the expression of the $\mathrm{H}$ antigen in one patient [53], while in another, expression of the $\mathrm{H}$ antigen was induced by therapy. Although no autohemolysis was seen in this patient, the potential for autoimmune reactions triggered by fucose therapy in SLC35C1-CDG has to be considered [23]. Moreover, no therapeutic benefit has been reported in some patients $[55,223]$. These response differences could be due to differences in mutational background [22], residual enzymatic function, overall clinical severity [23] or cellular mislocalization [27]. Further molecular and clinical data is warranted to further clarify the therapeutic potential of fucose administration to SLC35C1-CDG patients.

\subsubsection{Other Defects}

\section{TMEM165-CDG}

TMEM165-CDG (MIM: 614727) is a defect in a manganese $\left(\mathrm{Mn}^{2+}\right)$ transporter of the Golgi apparatus (Figure 5). $\mathrm{Mn}^{2+}$ supplementation has suppressed the glycosylation defect in vitro [142] and daily intake of Gal $(1 \mathrm{~g} / \mathrm{kg} /$ day $)$ led to improved biochemical parameters and $N$-glycosylation in two patients harbouring the same homozygous mutation and with normal $\mathrm{Mn}^{2+}$ levels, [70]. However, two different mutations R126H and E108G displayed altered $\mathrm{Mn}^{2+}$ sensitivity. This finding highlights the potential impact of distinct genetic alterations on therapy responses [36]. 


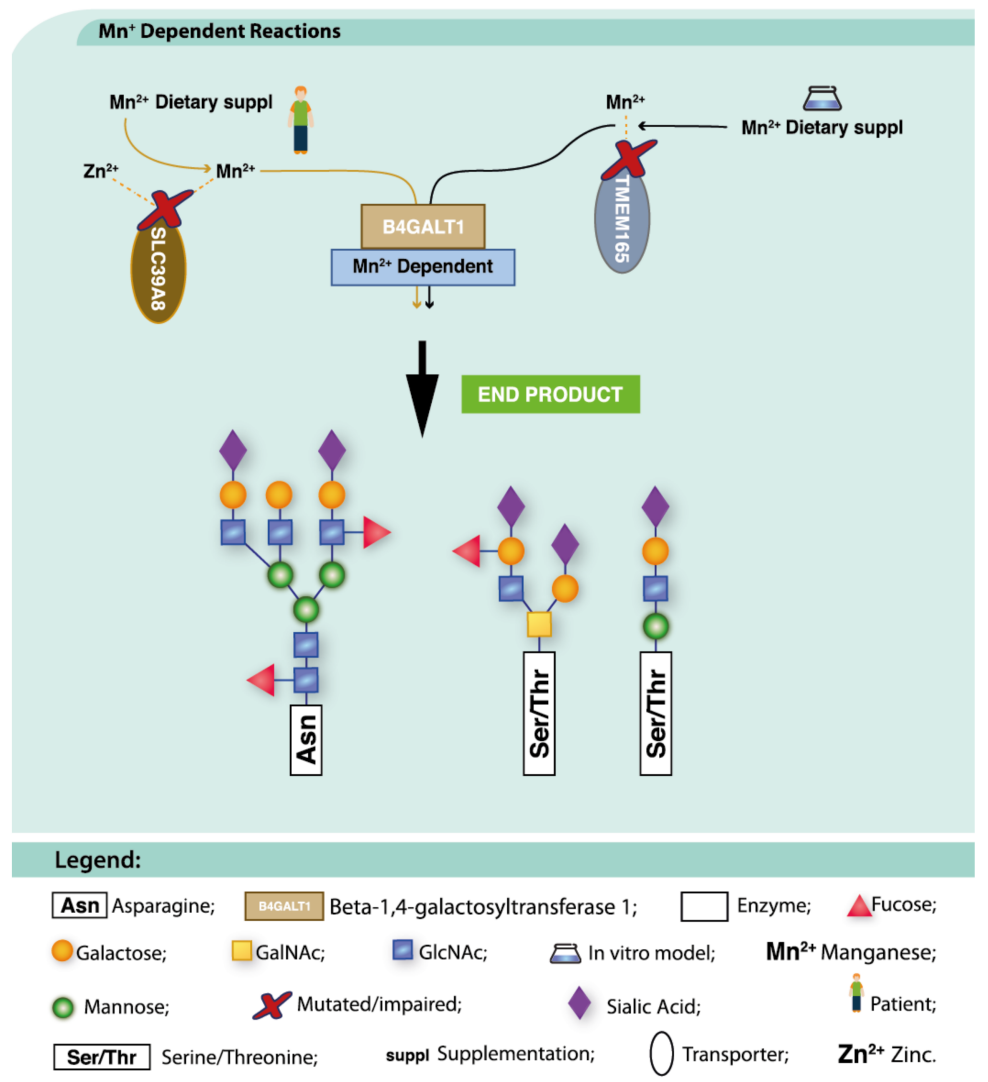

Figure 5. Dietary supplementation approaches under investigation for TMEM165-CDG and SLC39A8-CDG. Impaired transport of metal ions (dotted yellow lines), can be circumvented by $\mathrm{Mn}^{2+}$ supplementation (yellow and black lines). These therapeutic approaches aim to recover the metabolic pathways (black arrows) and ultimately, the final end product (bold black arrow).

\subsection{Defects Located in the ER-Golgi Intermediate Compartment( ERGIC)}

\subsubsection{Defects in Multiple and Other Glycosylation Pathways}

\section{CCDC115-CDG}

CCDC115-CDG (MIM: 616828) is caused by defects on the coiled-coil domain containing protein 115, one of the subunits of the Vacuolar $\mathrm{H}^{+}$ATPase (V-ATPase), the key proton pump for endo-lysosomal acidification. Disruption of V-ATPase function has been related to descreased intracellular iron levels which desrupt iron(II) prolyl hydroxylase (PHD) enzymes, activate hypoxia inducible transcription factors (HIFs) and impair transferrin uptake [106]. It has also been related to defective homeostasis of the Golgi apparatus [106,224]. CCDC115-CDG patients display a type 2 transferrin IEF, psychomotor disability, hypercholesterolemia, hypotonia and predominant liver involvement [3,224]. Supplementation of a CCDC115 knockout cellular model with iron (Fe(III)) citrate restored PHD enzymatic activity and HIF1 $\alpha$ turnover [106]. Replication of these experiements using patient-derived material would elucidate if iron supplementation could represent a therapeutic approach for these patients.

\section{TMEM199-CDG}

TMEM199-CDG (MIM: 616829) like CCDC115-CDG is caused by defects on one of the subunits of V-ATPase and indications suggest that TMEM199 and CCDC115 form a complex [106]. TMEM199-CDG patients present with mild liver dysfunction [225] and as for CCDC115-CDG, iron supplementation should also be investigated on patient-derived material to assess potential therapeutic value. 


\subsection{Defects Located at the Plasma Membrane}

\subsubsection{Defects in Multiple and Other Glycosylation Pathways}

\section{SLC39A8-CDG}

SLC39A8-CDG (MIM: 616721) is a disorder in $\mathrm{Mn}^{2+}$, zinc $\left(\mathrm{Zn}^{2+}\right)$ and cadmium $\left(\mathrm{Cd}^{2+}\right)$ transport, with a secondary impact on glycosylation due to the dependence of $\beta$-1,4-galactosyltransferases on $\mathrm{Mn}^{2+}$ (Figure 5). A multi-agent, phased therapeutic approach composed of Gal, uridine (to ensure sufficient UDP necessary for UDP-Gal synthesis), and eventually with the addition $\mathrm{Mn}^{2+}$ (due to undetectable levels of this element in the blood of the patient) has resulted in improved glycosylation after 2 weeks [226]. Combined treatment with both Gal and uridine has also shown substantial normalization of the glycosylation profile of a SLC39A8-CDG patient with a severe phenotype [227]. A follow-up of two patients on $\mathrm{Mn}^{2+}$ monotherapy for over 12 months showed significantly improved biochemical and clinical manifestations [228]. Although Gal therapy corrects the glycosylation defect, it is incapable of overcoming the impact of the lack of $\mathrm{Mn}^{2+}$ in $\mathrm{Mn}^{2+}$-dependent enzymes and processes [228].

\subsection{Defects Located at the Sarcolemma Membrane}

Defects in O-Mannosylglycan Synthesis

\section{ISPD-CDG}

ISPD-CDG (MIM: 614643, 616052) is caused by mutations in the ISPD gene. ISPD encodes the 2-C-methyl-D-erythritol 4-phosphate cytidylyltransferase that synthesizes CDP-ribitol [32,68]. Defects in ISPD lead to impaired $\alpha$-dystroglycan $(\alpha-D G) O$-mannosylation. In two elegant in vitro studies, addition of ribitol or ribitol-metabolites (CDP-Rbo) to the culture medium significantly increased $\alpha$-DG glycosylation, and restored laminin binding ability (Figure 6). Thus, ISPD-CDG patient-derived cells reacquired the capability to be glycosylated as well as their normal morphology [68,150], highlighting ribitol as a candidate therapeutic compound.

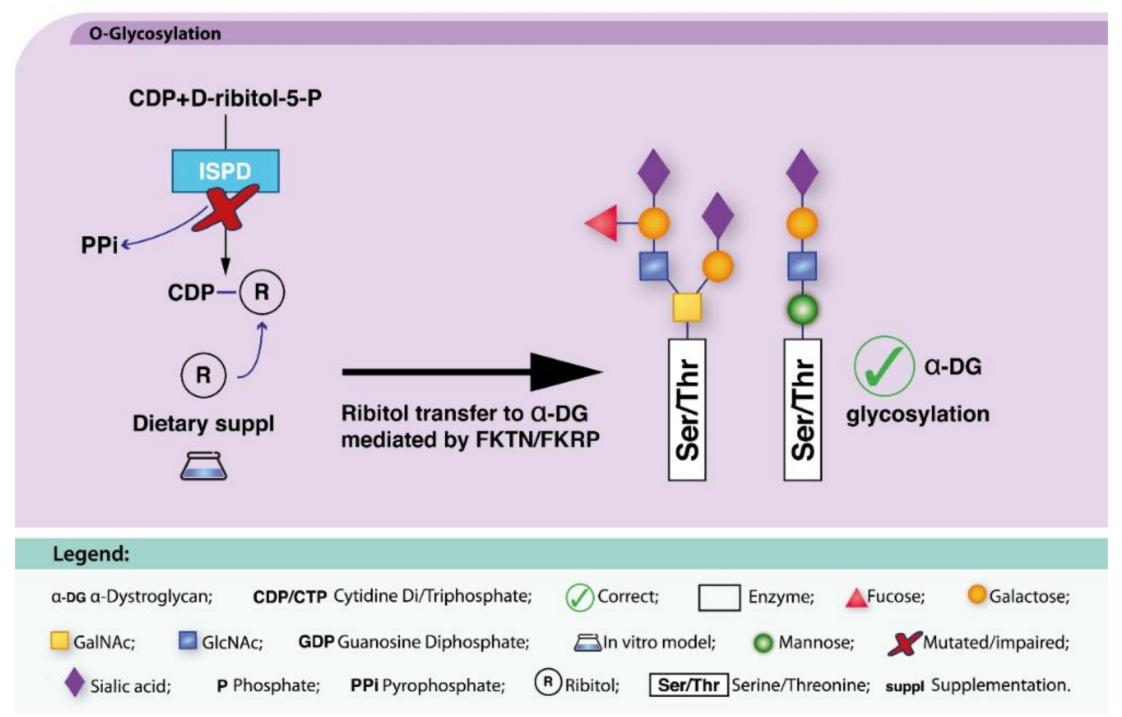

Figure 6. Dietary supplementation approaches under investigation for ISPD-CDG. ISPD synthetizes CDP-ribitol from CDP and D-ribitol-5-P, with the release of PPi (black and blue arrows). Ribitol supplementation (blue arrow) aims to circumvent ribitol shortage and ultimately the recovery of $\alpha$-DG glycosylation (bold back arrow). 


\section{Other Therapeutic Strategies}

Although supplementation either with sugars or other molecules has been successful in some $\mathrm{CDG}$, the majority of these disorders remain without treatment and hence, other strategies are being pursued.

\subsection{Pharmacological Chaperones}

Proteins exist in the intracellular medium in equilibrium between folded and unfolded states. Point mutations can shift this equilibrium towards the unfolded state inducing protein destabilization and aggregation [229]. Pharmacological chaperones (PCs) are small molecules that bind specifically to a protein and shift the equilibrium towards the folded state [230]. PCs can bind to the active site acting as competitor inhibitors or to allosteric sites of the protein and have no inhibitory effect [231].

PMM2-CDG has been classified as a misfolding disorder since the majority of mutations described are of the missense type and most mutants retain some residual enzymatic activity. In silico docking has demonstrated that it is possible to find ligands that stabilize PMM2 [232]. Thus, PCs present as a promising therapy [232-236]. Recently, a high-throughput screening of a commercially available library of 10,000 low molecular-weight compounds led to the identification of eight compounds that specifically stabilized the PMM2 protein. Further studies using oligomerization mutants, a cell-based disease model over-expressing the p.Asp65Tyr, p.Pro113Leu, p.Arg162Trp, and p.Thr237Met PMM2 mutants and in silico analysis narrowed the number to one compound, 1-(3-chlorophenyl)-3-3-bis(pyridine-2-yl)urea (compound VIII), that presented a viable chemical structure for further optimization [231]. These results represent the first proof-of-concept that PCs could be used as treatment for PMM2-CDG.

Another therapeutic strategy proposed for PMM2-CDG is the inhibition of MPI which is based on fact that the majority of Man-6-P is catabolized by MPI reducing the amounts of this precursor available for glycosylation [237]. A potent MPI inhibitor, MLS0315771, derived from the benzoisothiazolone series was shown to direct Man-6-P toward glycosylation in several different cell lines, including PMM2-CDG patient-derived fibroblasts, improving N-glycosylation [59,237]. Despite this positive outcome, the effect of MLS0315771 was dependent on the mutation type and the levels of residual PMM2 mutant activity, since five of the nine patient-derived cell lines did not present any improvement. This might be due to the presence of the p.Arg141His mutant, responsible for a complete lack of enzymatic activity. However, improvement was observed in one cell line bearing the p.Arg141His and p.Cys241Ser mutants, although residual activity was lower compared with other patient-derived cell lines which did not show improvement [59].

The effect of MLS0315771 was also tested in zebrafish embryos. An inhibitory effect of MPI was observed, although with toxic effects for concentrations above $2 \mu \mathrm{M}$. Thus, further compound optimization is necessary in order to maintain MPI inhibition while reducing toxicity [59].

\subsection{Antisense Therapy}

Although less frequent, the disruption of correct splicing by point mutations is estimated to represent about $15 \%$ of all the mutations described in the Human Gene Mutation Database $\left(\mathrm{HGMD}^{\circledR}\right)$ [238]. The disruption of conserved intron-exon junction sequences or other intronic regions, can lead to activation of cryptic splice-sites and inclusion of intronic sequences called pseudoexons $[238,239]$. Antisense therapy using morpholino oligonucleotides (AMO) has been tested in patient-derived fibroblasts for PMM2-CDG and TMEM165-CDG [238,239].

Several mutations affecting normal splicing of PMM2 have been described [239-241]. Vega et al. [239] described the use of AMOs designed towards the donor and acceptor cryptic splice sites of a pseudoexon activated by c.640-15479C $>$ T mutation to treat patient-derived fibroblasts. A normal splicing profile was obtained $24 \mathrm{~h}$ post-transfection in a sequence and dose-dependent manner and both protein amount and enzymatic activity were restored by 30 to $45 \%$ [239]. 
A deep intronic change, c.792+182G $>$ A leading to a pseudoexon insertion affecting the TMEM165 protein was described by Yuste-Checa et al. [238]. A specific AMO sequence targeting the intronic $5^{\prime}$ cryptic splice site was used, allowing the recovery of normal splicing profile and protein levels. AMO treatment also resulted in increased protein expression in the Golgi apparatus [238].

\subsection{Gene Therapy}

Since CDG are a group of monogenic disorders, they are potential candidates for gene therapy. In fact, in different disease model and patient cells, introduction of the normal copy of a faulty gene rescued the disease phenotype [34]. Gene therapy consists in the successful transfer and activation of a fully functional copy of an aberrant gene [242] in a patient cell system. In order to achieve this goal, a safe vehicle that protects the gene copy must be used. In comparison with adenoviral and retroviral vectors, adeno-associated virus (AAV) vectors represent a safer approach [242]. Gene therapy using the adeno-associated virus type 8 (AAV8) as vehicles for human GNE, was studied as a possible therapeutic strategy in GNE-CDG. Human and murine GNE myopathy muscle cells were transduced with the virus and they successfully expressed the transgene [61]. These results were also replicated in an animal model [243] with increased GNE expression in skeletal muscle, liver, kidney, heart and spleen 10 weeks after the injection. Mice were also injected at 47 weeks of age showing significant improvement in survival, motor and contractile performance and muscle size [243]. C57B16 wild-type mice between five and six weeks old were injected with two doses of the transgene which maintained a sustained expression for the six months follow-up period, without toxic effects [61].

Concerns regarding the possible adverse effects of GNE over-expression, led to another approach using an AAV-based trans-splicing (TS) mechanism to overcome the GNE M712T mutation [244]. TS can occur in mammals and is mediated by the spliceosome allowing the slicing of two different pre-mRNA molecules. The advantage of this system is the ability of correcting transcript defects by altering normal splicing process, while maintaining the original endogenous gene regulation [244]. The AAV-TS system was tested in human GNE myopathy muscle cells carrying the M712T mutation and was able to generate wild-type GNE transcripts, although with low efficiency [244].

AAV vector-targeted immune responses remain a major limitation of this gene-delivery tool in clinical practice. Different approaches such as liposomes or exosomes are being explored as safer delivery systems [245].

Phadke et al. [246], described the use of a GNE expressing vector complexed with a cationic liposome (GNE-lipoplex). The same vector had already successfully increased SA expression by transient transfection of GNE-deficient CHO-Lec3 cells lines [28].

$\mathrm{BALB} / \mathrm{c}$ mice were used to assess toxicity and GNE-lipoplex was administered intramuscularly (IM) or intravenous (IV) in a single dose of 10, 40 or $100 \mu \mathrm{g}$. No adverse effects were observed with the intermediate dose of GNE-lipoplex administered either IM or IV, with detection of human GNE mRNA in mice tissues [246]. GNE-lipoplex was also tested in a severely affected patient with acceptable safety and promising results $[247,248]$.

\subsection{Transplantation Options}

Symptom severity, disease progression and the lack of better suited therapeutic options have prompted organ transplantation as viable treatment option for IMDs [249-251].

\subsubsection{Liver Transplantation}

Liver involvement is present in several CDG (reviewed in Marques-da-Silva et al. [3]). Janssen et al. report the first instance of liver transplantation in a MPI-CDG patient [171]. The patient presented hepatomegaly and developed congenital hepatic fibrosis and portal hypertension with hepatic vein thrombosis. Oral mannose supplementation $(1 \mathrm{~g} / \mathrm{kg} /$ day $)$ was initiated at the age of 15 years, with some improvement, but due to therapy-resistance and progressive liver failure the patient was accepted for transplantation followed by major improvement [171]. 
Liver transplantation was also performed in two CCDC115-CDG patients [224]. The patients were siblings and presented hepatosplenomegaly, elevated serum transaminases and alkaline phosphatase. Both received liver transplants but unfortunately, the brother rejected the transplant twice and died. The sister is doing well after the procedure with normalization of serum aminotransferase levels and transferrin glycosylation profile [224].

Currently, liver transplant is an approved therapy in Europe for MPI-CDG, CCDC115-CDG and ATP6VAP1-CDG patients, and since the initially reported patients, additional () patients have been transplanted.

\subsubsection{Heart Transplantation}

The heart can also be affected in CDG patients (reviewed in Marques-da-Silva et al. [9]). Kapusta et al. reported cardiac pathology in nine patients diagnosed with DOLK-CDG (MIM: 610768), caused by dolichol kinase deficiency [252]. Cardiac manifestations varied from mild dilation to heart failure with death. Two of the patients died with acute symptoms of heart failure before CDG diagnosis, four patients diagnosed with mild DC were treated with supportive heart failure therapy (ACE inhibitors, $\beta$ blockers and diuretics), while three patients also with mild DC received heart transplants due to rapid deterioration. Despite a successful procedure, one of the patients died unexpectedly while in the other two, the symptoms stabilized [252]. Based on the successful transplantation in several mild patients [253], heart transplantation is an approved therapy for the pure cardiac form of DOLK-CDG.

Heart transplantation was also reported as an option for PGM1-CDG patients by Tegtmeyer et al. [65]. From a cohort of nineteen patients, six presented DC, cardiac arrest or both. Three of them were listed for heart transplantation [65].

\subsubsection{Cell Transplantation}

Hematopoietic stem cell transplantation from cord blood and bone marrow has been described as a lifesaving treatment for two PGM3-CDG affected children [42]. Both patients presented severe immunodeficiency which was successfully cured by the transplants [42]. Stem cell transplantation is currently an approved therapy for these patients in the USA.

Additionally, stem cell transplantation was planned for a MAGT1-CDG patient. The outcome of the procedure has not (yet) been reported [215].

\section{Observational and Interventional Clinical Trials}

The number of curative treatments for CDG and IMDs in general remains low [254]. Clinical trials, aimed to discover or verify the potential effects of a determined treatment, are crucial steps towards drug therapy approval, but several pitfalls exist in developing clinical trials for IMDs, especially related to the reduced number of subjects and the proposal of control groups for randomized controlled trials [254].

\subsection{Natural History Studies}

To assess the effects of a possible curative treatment it is essential to establish solid and quantifiable end-points based on patients' natural history. In CDG, this task can be especially difficult due to the broad range of different clinical manifestations observed.

In order to document the natural history of CDG patients accounting for the multisystem aspects of disease, researchers have developed and validated several rating scales designed to monitor disease progression.

The Nijmegen Paediatric CDG Rating Scale (NPCRS) is based on clinical symptoms and is composed of three sections of questions related to the disabilities suffered by CDG-affected children up to the age of 18 years. [255,256].

Despite evaluation of CNS involvement by the NPCRS, according to Serrano et al. [257], the cerebellar symptoms observed in PMM2-CDG patients are not specifically addressed. To address this, 
the International Cooperative Ataxia Rating Scale (ICARS), developed to assess cerebellar ataxia, was validated in a cohort of 13 patients [257] and also in a follow-up study of 20 patients [258]. Although ICARS has only been applied to PMM2-CDG, it could be transposable to all CDG with cerebellar involvement. MRI measurements [midsagittal vermis relative diameter (MVRD) and volume] for disease progression assessment have also been used [259].

A rating scale specific for PGM1-CDG was designed also based on clinical symptoms to grade disease severity and guide physicians in the diagnostics and prognosis counseling [260]. The Tulane PGM1-CDG Rating Scale (TPCRS) is structured similarly to the NPCRS and allowed the classification of a cohort of 27 PGM1-CDG patients [260].

In order to optimize care for GNE-CDG patients and also improve the design of clinical studies, the GNE Myopathy Functional Activity Scale (GNEM-FAS) was created [261]. This 25-item questionnaire was successfully applied to 47 subjects undergoing a Phase 2 study with extended release SA [261]. Another study of natural history in a cohort of 24 Japanese GNE-CDG patients was reported by Mori-Yoshimura et al. [262]. In order to broaden the investigation of clinical conditions and establish a long-term follow-up, a Japanese national GNE myopathy patient registry (Registration of Muscular Dystrophy; REMUDY) was created [262,263].

Several observational clinical trials have been registered in order to collect patient information for further studies (Table 4).

\subsection{Interventional Clinical Trials}

Several trials regarding dietary supplementation therapy for CDG are in clinical phase and are summarized in Table 4.

\subsubsection{GNE-CDG}

The effect of ManNAc in GNE-CDG patients was studied in a phase 1, randomized, placebo-controlled, double-blind study (clinicaltrials.gov NCT01634750) [264]. Based on the results of this clinical trial a regimen of $6 \mathrm{~g}$ administered twice a day was selected for future clinical trials [264]. The effects of $3 \mathrm{~g}$ and $6 \mathrm{~g}$ ManNAc administered twice a day for a time frame of 120 days is under study in an open label, phase 2 study (clinicaltrials.gov NCT02346461).

The administration of Ace-ER tablets with a proper formulation has also been studied in phase 1 and 2 clinical trials [265], (clinicaltrials.gov NCT01359319, NCT01517880). These showed that this formulation increased serum free SA levels, with significant improvement of muscle strength in the upper extremities and no serious adverse effects reported. To further confirm the results obtained, an international randomized, double-blind, placebo-controlled phase 3 study is being conducted (clinicaltrials.gov NCT02736188). The results of this trial have not been reported yet.

The possible therapeutic effects of immune globulin were also studied in a cohort of 4 patients (clinicaltrials.gov NCT00195637) [266]. Patients presented qualitative improvement for approximately three weeks, after which a decline in function was described [266].

\subsubsection{PGM1-CDG}

The effect of Gal supplementation in PGM1-CDG patients was evaluated in a cohort of nine individuals in a pilot study [208] (clinicaltrials.gov NCT02955264). Treatment was well tolerated and no adverse events, aside from gastroenteritis in one patient, were registered. Liver function and coagulation parameters improved. Serum transferrin glycosylation improved in 8 patients. One patient continued Gal therapy $(1 \mathrm{~g} / \mathrm{kg} /$ day) for an additional period of 12 months during which all the parameters that improved and normalized during the trial remained stable [208]. Despite the positive results reported it is important to highlight that the study sample was small and laboratory baseline values were inconsistent in several function tests [208]. Gal treatment is now an approved dietary supplementation for the therapy of PGM1-CDG in Europe and the USA.

Patients with other CDG have also been included in this currently ongoing clinical trial (NCT02955264). 
Table 4. Summary of the clinical trials registered at ClinicalTrials.gov and ClinicalTrialsregister.eu, related to Congenital Disorders of Glycosylation. The results were obtained using the following keywords: Congenital Disorders of Glycosylation, GNE, PMM2-CDG and Cerebellar Disease.

\begin{tabular}{|c|c|c|c|c|c|c|}
\hline Study Identifier & Status & Study Title & Condition & Intervention & $\begin{array}{c}\text { Study } \\
\text { Characteristics }\end{array}$ & Study Type \\
\hline NCT02089789§ & Active, recruiting & $\begin{array}{l}\text { Clinical and basic investigations into known } \\
\text { and suspected Congenital Disorders of } \\
\text { Glycosylation }\end{array}$ & CDG & N.A & N.A & Observational \\
\hline NCT02503267 $§$ & Active, recruiting & $\begin{array}{l}\text { Incidence and consequences of Disorders of } \\
\text { Glycosylation in patients with conotruncal and } \\
\text { septal heart defects (CARDIoG) }\end{array}$ & CDG & N.A & N.A & Observational \\
\hline NCT03250728 § & Active, not recruiting & $\begin{array}{l}\text { Role of the endothelium in stroke-like episode } \\
\text { among CDG Patients (PECDG) }\end{array}$ & CDG & N.A & N.A & $\begin{array}{l}\text { Interventional } \\
\text { Peripheral blood } \\
\text { puncture }\end{array}$ \\
\hline $\begin{array}{l}\text { NCT02955264 } \\
{[208]}\end{array}$ & Active, recruiting & $\begin{array}{l}\text { Using D-Galactose as a food supplement in } \\
\text { Congenital Disorders of Glycosylation }\end{array}$ & CDG & $\begin{array}{l}\text { Drug: D-galactose (dietary } \\
\text { supplement) } \\
\text { Administration: Oral }\end{array}$ & $\begin{array}{l}\text { Open label, single } \\
\text { group }\end{array}$ & $\begin{array}{l}\text { Interventional } \\
\text { Phase } 2\end{array}$ \\
\hline NCT02346461§ & Active, not recruiting & $\begin{array}{l}\text { An open label Phase } 2 \text { study of ManNAc in } \\
\text { subjects with GNE Myopathy }\end{array}$ & -GNE-CDG & $\begin{array}{c}\text { Drug: ManNAc } \\
\text { Administration: Oral }\end{array}$ & $\begin{array}{c}\text { Open label, } \\
\text { Non-randomized }\end{array}$ & $\begin{array}{l}\text { Interventional } \\
\text { Phase } 2\end{array}$ \\
\hline$\underset{[264]}{\mathrm{NCT} 0163450 \S}$ & Completed & $\begin{array}{l}\text { Phase I clinical trial of ManNAc in patients with } \\
\text { GNE Myopathy or Hereditary Inclusion Body } \\
\text { Myopathy (HIBM) }\end{array}$ & $\begin{array}{l}\text {-GNE-CDG } \\
\text {-Hereditary Inclusion Body } \\
\text { Myopathy (HIBM) }\end{array}$ & $\begin{array}{l}\text { Drug: ManNAc } \\
\text { Administration: Oral }\end{array}$ & $\begin{array}{c}\text { Randomized, } \\
\text { double-blind, } \\
\text { placebo-controlled }\end{array}$ & $\begin{array}{l}\text { Interventional } \\
\text { Phase } 1\end{array}$ \\
\hline $\begin{array}{l}\text { NCT02736188 } ₫ \infty \\
2016-000360-42 * \infty\end{array}$ & Active, not recruiting & $\begin{array}{l}\text { Study to evaluate the safety and efficacy of } \\
\text { Ace-ER Tablets in patients with GNE Myopathy } \\
\text { or Hereditary Inclusion Body Myopathy }\end{array}$ & $\begin{array}{c}\text {-GNE-CDG } \\
\text {-HIBM } \\
\text {-Quadriceps Sparing } \\
\text { Myopathy } \\
\text {-Distal Myopathy With } \\
\text { Rimmed Vacuoles } \\
\end{array}$ & $\begin{array}{l}\text { Drug: Aceneuramic Acid } \\
\text { Extended-Release Tablets } \\
\text { (Ace-ER) } \\
\text { Administration: Oral }\end{array}$ & $\begin{array}{l}\text { Open label, single } \\
\text { group }\end{array}$ & $\begin{array}{l}\text { Interventional } \\
\quad \text { Phase } 3\end{array}$ \\
\hline $\begin{array}{l}\text { NCT02731690 } \approx \approx \\
2015-004553-41 * \approx\end{array}$ & Active, not recruiting & $\begin{array}{l}\text { A study to evaluate the safety of Aceneuramic } \\
\text { Acid Extended Release (Ace-ER) tablets in GNE } \\
\text { Myopathy (GNEM) (Also Known as Hereditary } \\
\text { Inclusion Body Myopathy (HIBM)) patients } \\
\text { with severe ambulatory impairment }\end{array}$ & -GNE-CDG & $\begin{array}{l}\text { Drug: Aceneuramic Acid } \\
\text { Extended-Release tablets } \\
\text { (Ace-ER) } \\
\text { Administration: Oral }\end{array}$ & $\begin{array}{l}\text { Open label, single } \\
\text { group }\end{array}$ & $\begin{array}{l}\text { Interventional } \\
\text { Phase } 2\end{array}$ \\
\hline $\begin{array}{c}\text { NCT01517880 } \\
{[265]}\end{array}$ & Completed & $\begin{array}{l}\text { A phase } 2 \text { study to evaluate the dose and } \\
\text { pharmacodynamic efficacy of Sialic } \\
\text { Acid-Extended Release (SA-ER) tablets in } \\
\text { patients with GNE Myopathy or Hereditary } \\
\text { Inclusion Body Myopathy (HIBM) }\end{array}$ & $\begin{array}{l}\text {-GNE-CDG } \\
\text {-HIBM }\end{array}$ & $\begin{array}{l}\text { Drug: Sialic Acid Extended } \\
\text { Release (SA-ER) } \\
\text { Administration: Oral }\end{array}$ & $\begin{array}{l}\text { Randomized, } \\
\text { double-blind, } \\
\text { placebo-controlled }\end{array}$ & $\begin{array}{l}\text { Interventional } \\
\quad \text { Phase } 2\end{array}$ \\
\hline
\end{tabular}


Table 4. Cont.

\begin{tabular}{|c|c|c|c|c|c|c|}
\hline Study Identifier & Status & Study Title & Condition & Intervention & $\begin{array}{c}\text { Study } \\
\text { Characteristics }\end{array}$ & Study Type \\
\hline NCT01830972§ & Completed & $\begin{array}{l}\text { An open label phase } 2 \text { extension study of higher } \\
\text { dose Sialic Acid (ER Tablets + IR Capsules) in } \\
\text { patients with GNE Myopathy }\end{array}$ & -GNE-CDG & $\begin{array}{l}\text { Drug: Sialic Acid Extended } \\
\text { Release (SA-ER) } \\
\text { Sialic Acid Immediate Release } \\
\text { (SA-IR) } \\
\text { Administration: Oral }\end{array}$ & $\begin{array}{c}\text { Open label, } \\
\text { non-randomized }\end{array}$ & $\begin{array}{l}\text { Interventional } \\
\text { Phase } 2\end{array}$ \\
\hline $\begin{array}{c}\text { NCT01359319 } \\
{[265]}\end{array}$ & Completed & $\begin{array}{l}\text { Safety and pharmacokinetics of Sialic Acid } \\
\text { tables in patients With Hereditary Inclusion } \\
\text { Body Myopathy (HIBM) }\end{array}$ & $\begin{array}{l}\text {-GNE-CDG } \\
\text {-HIBM }\end{array}$ & $\begin{array}{l}\text { Drug: Sialic Acid Extended } \\
\text { Release (SA-ER) tablets } \\
\text { Administration: Oral }\end{array}$ & $\begin{array}{l}\text { Open label, } \\
\text { non-randomized, } \\
\text { single group }\end{array}$ & $\begin{array}{l}\text { Interventional } \\
\text { Phase } 1\end{array}$ \\
\hline NCT02377921 $§$ & Completed & $\begin{array}{l}\text { Phase } 3 \text { randomized, double-blind, } \\
\text { placebo-controlled study to evaluate Sialic Acid } \\
\text { in patients with GNE Myopathy or Hereditary } \\
\text { Inclusion Body Myopathy (HIBM) }\end{array}$ & $\begin{array}{l}\text {-GNECDG } \\
\text {-HIBM }\end{array}$ & $\begin{array}{l}\text { Drug: Sialic Acid Tablets } \\
\text { (UX001) } \\
\text { Administration: Oral }\end{array}$ & $\begin{array}{l}\text { Randomized, } \\
\text { double-blind, } \\
\text { placebo-controlled }\end{array}$ & $\begin{array}{c}\text { Interventional } \\
\text { Phase } 3\end{array}$ \\
\hline $\begin{array}{l}\text { NCT00195637 } \\
{[266]}\end{array}$ & Completed & $\begin{array}{l}\text { Intravenous immune globulin to treat } \\
\text { Hereditary Inclusion Body Myopathy }\end{array}$ & $\begin{array}{l}\text {-GNE-CDG } \\
\text {-HIBM }\end{array}$ & $\begin{array}{l}\text { Drug: Immune Globulin } \\
\text { Administration: intravenous }\end{array}$ & $\begin{array}{l}\text { Pilot study with } 4 \\
\text { participants }\end{array}$ & $\begin{array}{l}\text { Interventional } \\
\text { Phase } 1\end{array}$ \\
\hline NCT01236898§ & Completed & $\begin{array}{l}\text { Pharmacokinetic study on } \\
N \text {-acetylneuraminic Acid }\end{array}$ & $\begin{array}{l}\text {-GNE-CDG } \\
\text {-HIBM }\end{array}$ & $\begin{array}{l}\text { Drug: } N \text {-acetylneuraminic acid } \\
\text { (anhydride) (NPC-09) } \\
\text { Administration: Oral }\end{array}$ & $\begin{array}{l}\text { Open label, } \\
\text { non-randomized, } \\
\text { single group }\end{array}$ & $\begin{array}{l}\text { Interventional } \\
\text { Phase } 1\end{array}$ \\
\hline NCT01784679§ & Active, recruiting & $\begin{array}{l}\text { GNE-Myopathy disease monitoring program } \\
\text { (GNEM-DMP): a registry and prospective } \\
\text { observational natural history study to assess } \\
\text { GNE Myopathy or Hereditary Inclusion Body } \\
\text { Myopathy (HIBM) }\end{array}$ & $\begin{array}{l}\text {-GNE-CDG } \\
\text {-HIBM }\end{array}$ & N.A & N.A & Observational \\
\hline NCT02196909§ & Active, not recruiting & $\begin{array}{l}\text { Clinical, biological and NMR outcome measures } \\
\text { study for Hereditary Inclusion Body Myopathy } \\
\text { due to mutation of UDP- } N \text {-acetylglucosamine } \\
\text { 2-epimerase/ } N \text {-acetylmannosamine kinase } \\
\text { gene (GNE) (ClinBio-GNE) }\end{array}$ & $\begin{array}{l}\text {-GNE-CDG } \\
\text {-HIBM }\end{array}$ & N.A & N.A & $\begin{array}{c}\text { Interventional } \\
\text { Parallel } \\
\text { assignment with } \\
\text { blood and urine } \\
\text { collection }\end{array}$ \\
\hline NCT01902940§ & Completed & Natural history in CCFDN and IBM syndromes & $\begin{array}{l}\text {-GNE-CDG } \\
\text {-HIBM }\end{array}$ & N.A & N.A & Observational \\
\hline NCT01417533§ & Active, recruiting & $\begin{array}{l}\text { A natural history study of patients with GNE } \\
\text { Myopathy }\end{array}$ & $\begin{array}{l}\text {-GNE-CDG } \\
\text {-HIBM }\end{array}$ & N.A & N.A & Observational \\
\hline NCT03173300§ & Active, recruiting & $\begin{array}{l}\text { Natural history study protocol in } \\
\text { PMM2-CDG (CDG-Ia) }\end{array}$ & PMM2-CDG & N.A & N.A & Observational \\
\hline 2017-000810-44 * & Active & $\begin{array}{l}\text { Phase II clinical trial to evaluate the } \\
\text { effectiveness and safety of acetazolamide in the } \\
\text { treatment of cerebellar syndrome in patients } \\
\text { with PMM2-CDG deficiency }\end{array}$ & PMM2-CDG & $\begin{array}{l}\text { Drug: Acetazolamide } \\
\text { Administration: Oral }\end{array}$ & $\begin{array}{l}\text { Randomized, open } \\
\text { labeled }\end{array}$ & $\begin{array}{l}\text { Interventional } \\
\text { Phase } 2\end{array}$ \\
\hline
\end{tabular}

$\S$ Accession number for ClinicalTrials.gov [267]; * Accession number for ClinicalTrialsregister.eu [268]; ${ }^{\infty}$ Despite the current status, this trial has been stopped; $\approx$ Despite the current status, this trial has been closed; N.A.-Not applied. 


\section{Discussion}

Due to the multisystem presentation of CDG a "one size fits all" therapeutic solution is not feasible. Knowledge on the specific pathophysiological aspects of each CDG is fundamental to achieve better diagnostics, disease management and therapeutic solutions. Patient-derived material has been extensively used for diagnosis and research, but it presents limitations and some findings cannot be replicated in patients (e.g., Man supplementation in PMM2-CDG) $[46,47,52,194,198]$ while others may be misleading as demonstrated by the null effect of Gal supplementation in SLC35A2-CDG patient-derived fibroblasts [221]. The generation of patient-derived iPSCs [93] will allow the investigation of disease mechanisms influencing embryonic development. The possibility of organoid generation also opens a new research avenue in which organ specific disease mechanisms and therapeutic approaches can be investigated. The generation of animal models for CDG can be challenging since glycosylation is an essential process and its severe impairment may not be compatible with life causing embryonic and/or neonatal lethality [74,77,121,124]. Other factors should also be taken into consideration regarding animal models, such as human disease phenotype recapitulation and phenotypic variability, since different genetic backgrounds within the same species can cause different disease presentations [76,81,269].

In recent years, an increasing number of studies evaluating the potential of dietary supplementation in CDG have emerged encouraged by the success of Man therapy in MPI-CDG. Nutritional therapies present many advantages, like being inexpensive food supplements, easily available and afforded by the families. To date, dietary supplementation strategies have been experimented on 21 CDG types using different disease models with a wide-range of results. These therapies are also in distinct phases of development (Figure S1). Some have only been tested in vitro, while others have already been trialed in humans. The recognition of dietary supplementation strategies as approved therapies will reduce costs facilitating access to the patients.

Nutritional supplementation in CDG such as, CAD-CDG [69], GNE-CDG [264,265], PGM1-CDG [65] and SLC35C1-CDG [53,270] have shown positive results, which has fueled the interest in this field. Additionally, as more knowledge about the affected molecular mechanisms responsible for disease phenotypes is built, increasingly targeted and precise therapies - some based on dietary compounds - used either alone [228] or in combinatory schemes [65,200] are being developed. Despite this, much remains to be elucidated in terms of the uptake, bioavailability, half-life, excretion, and toxicity of dietary supplements. Other parameters, such as dosage, route of administration, effectiveness/safety of both pre-natal and post-natal therapy, as well as long term administration consequences also need optimization and clarification.

The development of personalized medicine based on the patients' genotype rather than phenotype has led to other approaches. PCs have been developed for several disorders [229,230] and are based on the existence of a protein with some residual activity that can be recovered. Thus, severe point mutations affecting the catalytic site or that severely impair the oligomerization state of the protein are not amenable to this therapy. As for gene and antisense therapy, the pitfalls rely on a safe and efficient delivery mode that can reach both peripheral organs and cross the blood brain barrier (BBB), as many CDG present neurologic impairment. Regarding organ transplantation, issues related to donor/organ availability and procedure complications have to be taken in account.

Solid preclinical investigation using both in vitro and in vivo models, stable and reliable disease biomarkers, good screening methods and extensive knowledge of disease natural history are the basis for clinical trials. Hence, the drug development process is a high cost and time consuming process. According to the European Medicines Agency (EMA), incentives for the development of Orphan drugs for IMDs have increased, in order to spike pharmaceutical companies' interest. This has already resulted in an increase of the number of orphan drugs approved. Nevertheless, there is only about $10 \%$ chance that a new therapy will be successfully approved by government regulatory agencies [271] and even then there are no guaranties that these drugs will reach the target patients due to country specific reimbursement issues [272]. Drug repositioning which is based on the use of 
existing and approved drugs for other diseases in therapeutic areas different from those with marketing authorization has become a possible solution $[271,273,274]$. Acetazolamide, a carbonic anhydrase (CA) inhibitor, can be considered a successful case of drug repositioning, since it has been used in the prophylaxis and treatment of acute mountain sickness [275], hydroxychloroquine retinopathy [276], hyperphosphatemic familial tumoral calcinosis [277] and also in the treatment of disorders associated with ataxia [278]. Now it is being evaluated for cerebellar involvement in PMM2-CDG (Clinical trial identifier 2017-000810-44).

However, to use this approach it is fundamental to be aware of different DNA sequence variants that cause or influence disease phenotype. Westphal et al. described a frequent mild mutation in ALG6 that can influence disease severity of PMM2-CDG patients [279]. The same mutation was also identified in a case of CDG type I associated with low dehydrodolichol diphosphate synthase (DHDDS) [280]. This indicates that other unknown variants might be associated with disease mechanism. Genome-wide association, ChIP-seq and RNA-seq studies, allied to strong computational analysis can give valuable information regarding the expression of different genes in CDG patients-derived samples.

Research advances during the last few years open new therapeutic avenues for CDG. In this review we have collected and selected information regarding several aspects involved in the development of therapies in order to facilitate research and increase information in this area. All the information collected regading disease models and the different therapeutic approaches is summarized in Table S1. By systematizing existing knowledge on and therapeutic solutions for CDG, we hope to intensify further research, and, at the same time promote patient-involvement in research, and ensure that CDG patients receive the best possible care.

\section{Methods}

For this review, a combination of specific keywords related to therapies, clinical trials, animal and cellular models, biomarkers and CDG was used to search the Medline database, using PubMed [281] as the search engine. After the data collection the possible duplicate registries were eliminated and a refinement of the results was performed based on the title and abstract of each publication. After this step, the selected articles were read and the ones matching the selection criteria were included. Inclusion/exclusion criteria were the following:

(a) Only English-written manuscripts were included;

(b) Articles reporting biomarkers, in vitro and/or in vivo models, compassionate use or clinical trials of therapies in CDG were included;

(c) Only articles reporting CDG with therapies under development (compassionate use, clinical research) or already approved were included;

(d) Reviews were excluded, although we have included some examples for contextualization purposes;

For information about clinical trials, both the European [268] and American [267] web pages were consulted. Information about mouse models was also retrieved from the Jackson Laboratories web page [86]. More information about the selection process can be seen in Figures S2 and S3.

Supplementary Materials: Supplementary materials can be found at http:/ / www.mdpi.com/1422-0067/19/5/ $1304 /$ s1.

Author Contributions: Sandra Brasil, Carlota Pascoal and Rita Francisco performed bibliographic search and wrote the manuscript, all authors critically reviewed the manuscript; Vanessa dos Reis Ferreira developed the concept of the paper.

Acknowledgments: This work was supported by the CDG Professionals and Patient Associations International Network (CDG\& Allies_PPAIN). Francisco R. was supported by a scholarship (SFRH/BD/124326/2016) from Fundação para a Ciência e Tecnologia (FCT). The authors kindly acknowledge the CDG patient representatives; Nick Vazques, Claudia Graetsch-Vazques, Rana Atwi, Merell Liddle and Rosália Félix for their revision of the manuscript and input on health literacy. The authors confirmed independence from any sponsors.

Conflicts of Interest: The authors declare no conflict of interest. 


\section{Abbreviations}

\begin{tabular}{|c|c|}
\hline$\alpha-\mathrm{DG}$ & $\alpha$-Dystroglycan \\
\hline AAV & Adeno-associated virus \\
\hline $\mathrm{Ac}_{4} \mathrm{ManNAc}$ & Peracetylated $N$-acetylmannosamine \\
\hline $\mathrm{ACE}$ & Angiotensin-converting enzyme \\
\hline AGA & Aspartylglucosaminidase \\
\hline $\mathrm{AMO}$ & Antisense morpholino oligonucleotides \\
\hline ApoC-III & Apolipoprotein C-III \\
\hline ATase & Amidophosphoribosyltransferase \\
\hline ATCase & Aspartate transcarbamoylase \\
\hline BBB & Blood brain barrier \\
\hline CCFDN & Congenital cataracts-facial dysmorphism-neuropathy syndrome \\
\hline CDG & Congenital disorder(s) of glycosylation \\
\hline CDP & Cytidine diphosphate \\
\hline $\mathrm{CHO}$ & Chinese hamster ovary \\
\hline CMP & Cytidine monophosphate \\
\hline CNS & Central nervous system \\
\hline CPSase & Carbamoyl phosphate synthetase \\
\hline CPY & Carboxypeptidase $\mathrm{Y}$ \\
\hline CTP & Cytosine triphosphate \\
\hline DC & Dilated cardiomyopathy \\
\hline DFCs & Dorsal forerunner cells \\
\hline DHOase & Dihydroorotase \\
\hline DIGE & 2D-Differential gel electrophoresis \\
\hline ER & Endoplasmic reticulum \\
\hline FKTN & Fukutin \\
\hline FKRP & Fukutin related protein \\
\hline Fuc & Fucose \\
\hline GABA & $\gamma$-Amino butyric acid \\
\hline Gal & Galactose \\
\hline GalNAc & $\mathrm{N}$-Acetylgalactosamine \\
\hline GALE & UDP-galactose-4-epimerase \\
\hline GALK & Galactokinase \\
\hline GALT & Galactose-1-phosphate uridyl transferase \\
\hline GDP & Guanosine diphosphate \\
\hline Glc & Glucose \\
\hline GlcNAc & $N$-Acetylglucosamine \\
\hline GPI & Glycosylphosphatidylinositol \\
\hline GSL & Glycosphingolipid \\
\hline HDAC & Histone deacetylase inhibitors \\
\hline HIBM & Hereditary inclusion body myopathy \\
\hline HIFs & Hypoxia inducible factors \\
\hline HIF1 $\alpha$ & Hypoxia inducible factor 1-alpha \\
\hline IBM & Inclusion body myopathy \\
\hline ICAM-1 & Intercellular adhesion molecule 1 \\
\hline IEM & Inborn errors of metabolism \\
\hline IM & Intramuscular \\
\hline IMD & Inherited metabolic disease \\
\hline iPSCs & Induced pluripotent stem cells \\
\hline IV & Intravenous \\
\hline KV & Kupffer's vesicle \\
\hline LLO & Lipid-linked oligosaccharides \\
\hline Magts & Mannoside acetylglucosaminyltransferases \\
\hline Man & Mannose \\
\hline Man-1-P & Mannose-1-phosphate \\
\hline Man-6-P & Mannose-6-phosphate \\
\hline
\end{tabular}




$\begin{array}{ll}\text { ManN } & \text { D-mannosamine } \\ \text { ManNAc } & \text { N-acetylmannosamine } \\ \text { MCAHS2 } & \text { Multiple congenital anomalies-hypotonia-seizures syndrome-2 } \\ \text { MPG1 } & \text { Mannose-1-phosphate guanylyltransferase } \\ \text { MPI } & \text { Phosphomannose isomerase } \\ \text { MPP } & \text { Matrix metalloproteinase } \\ \text { MS } & \text { Mass spectrometry } \\ \text { NCAM } & \text { Neural cell adhesion molecule } \\ \text { NGT } & \text { UDP-N-acetylglucosamine transporter } \\ \text { PI } & \text { Phosphatidylinositol } \\ \text { PC } & \text { Pharmacological chaperone } \\ \text { PMM2 } & \text { Phosphomannomutase 2 } \\ \text { PUFA } & \text { Polyunsaturated fatty acids } \\ \text { Rbo } & \text { Ribitol } \\ \text { SA } & \text { Sialic acid } \\ \text { TF } 4 & \text { Thyroxine } \\ \text { TS } & \text { trans-Splicing } \\ \text { TSH } & \text { Thyroid stimulating hormone } \\ \text { UDP } & \text { Uridine diphosphate } \\ \text { UGT } & \text { UDP-galactose transporter } \\ \text { UMPS } & \text { Uridine monophosphate synthetase } \\ \text { uPAR } & \text { Urokinase plasminogen activator receptor } \\ \text { UPR } & \text { Unfolded protein response } \\ \text { UTP } & \text { Uridine triphosphate } \\ \text { VLC-PUFA } & \text { Very long chain polyunsaturated fatty acids } \\ \text { Vma3p } & \text { 17-kDa Proteolipid subunit of vacuolar ATPase } \\ \text { Vma11p } & \text { V-Type proton ATPase 16 kDa proteolipid subunit 2 } \\ \text { Vph1p } & \text { 100 kDa Subunit a of vacuolar-ATPase } V_{0} \text { domain } \\ \text { XMEN } & \text { X-linked immunodeficiency with magnesium defect, EBV infections and neoplas } \\ & \end{array}$

\section{References}

1. Péanne, R.; de Lonlay, P.; Foulquier, F.; Kornak, U.; Lefeber, D.J.; Morava, E.; Pérez, B.; Seta, N.; Thiel, C.; Van Schaftingen, E.; et al. Congenital disorders of glycosylation (CDG): Quo vadis? Eur. J. Med. Genet. 2017. [CrossRef] [PubMed]

2. Hennet, T. Diseases of glycosylation beyond classical congenital disorders of glycosylation. Biochim. Biophys. Acta Gen. Subj. 2012, 1820, 1306-1317. [CrossRef] [PubMed]

3. Marques-da-Silva, D.; dos Reis Ferreira, V.; Monticelli, M.; Janeiro, P.; Videira, P.A.; Witters, P.; Jaeken, J.; Cassiman, D. Liver involvement in congenital disorders of glycosylation (CDG). A systematic review of the literature. J. Inherit. Metab. Dis. 2017, 40, 195-207. [CrossRef] [PubMed]

4. Van Scherpenzeel, M.; Willems, E.; Lefeber, D.J. Clinical diagnostics and therapy monitoring in the congenital disorders of glycosylation. Glycoconj. J. 2016, 33, 345-358. [CrossRef] [PubMed]

5. Jaeken, J.; Péanne, R. What is new in CDG? J. Inherit. Metab. Dis. 2017, 1-17. [CrossRef] [PubMed]

6. Jaeken, J. Congenital disorders of glycosylation (CDG): It's (nearly) all in it! J. Inherit. Metab. Dis. 2011, 34, 853-858. [CrossRef] [PubMed]

7. Pérez-Cerdá, C.; Girós, M.L.; Serrano, M.; Ecay, M.J.; Gort, L.; Pérez Dueñas, B.; Medrano, C.; García-Alix, A.; Artuch, R.; Briones, P.; et al. A Population-Based Study on Congenital Disorders of Protein $N$ - and Combined with O-glycosylation Experience in Clinical and Genetic Diagnosis. J. Pediatr. 2017, 183, 170-177.e1. [CrossRef] [PubMed]

8. Bakar, N.A.; Lefeber, D.J.; Scherpenzeel, M. Van Clinical glycomics for the diagnosis of congenital disorders of glycosylation. J. Inherit. Metab. Dis. 2018. [CrossRef]

9. Marques-da-Silva, D.; Francisco, R.; Webster, D.; dos Reis Ferreira, V.; Jaeken, J.; Pulinilkunnil, T. Cardiac complications of congenital disorders of glycosylation (CDG): A systematic review of the literature. J. Inherit. Metab. Dis. 2017, 40, 657-672. [CrossRef] [PubMed] 
10. Francisco, R.; Pascoal, C.; Marques-da-Silva, D.; Morava, E.; Gole, G.A.; Coman, D.; Jaeken, J.; Dos Reis Ferreira, V. Keeping an eye on congenital disorders of $O$-glycosylation: A systematic literature review. J. Inherit. Metab. Dis. 2018. [CrossRef] [PubMed]

11. Timal, S.; Hoischen, A.; Lehle, L.; Adamowicz, M.; Huijben, K.; Sykut-cegielska, J.; Paprocka, J.; Jamroz, E.; Van spronsen, F.J.; Körner, C.; et al. Gene identification in the congenital disorders of glycosylation type i by whole-exome sequencing. Hum. Mol. Genet. 2012, 21, 4151-4161. [CrossRef] [PubMed]

12. Pacheco-Cuéllar, G.; Gauthier, J.; Désilets, V.; Lachance, C.; Lemire-Girard, M.; Rypens, F.; Le Deist, F.; Decaluwe, H.; Duval, M.; Bouron-Dal Soglio, D.; et al. A Novel PGM3 Mutation Is Associated With a Severe Phenotype of Bone Marrow Failure, Severe Combined Immunodeficiency, Skeletal Dysplasia, and Congenital Malformations. J. Bone Miner. Res. 2017, 32, 1853-1859. [CrossRef] [PubMed]

13. Jaeken, J.; Hennet, T.; Matthijs, G.; Freeze, H.H. CDG nomenclature: Time for a change! Biochim. Biophys. Acta Mol. Basis Dis. 2009, 1792, 825-826. [CrossRef] [PubMed]

14. Thiel, C.; Körner, C. Therapies and therapeutic approaches in Congenital Disorders of Glycosylation. Glycoconj. J. 2013, 30, 77-84. [CrossRef] [PubMed]

15. Witters, P.; Cassiman, D.; Morava, E. Nutritional therapies in congenital disorders of glycosylation (CDG). Nutrients 2017, 9, 1222. [CrossRef] [PubMed]

16. Thiel, C.; Körner, C. Mouse models for congenital disorders of glycosylation. J. Inherit. Metab. Dis. 2011, 34, 879-889. [CrossRef] [PubMed]

17. Deutscher, S.L.; Nuwayhid, N.; Stanley, P.; Briles, E.I.B.; Hirschberg, C.B. Translocation across golgi vesicle membranes: A CHO glycosylation mutant deficient in CMP-sialic acid transport. Cell 1984, 39, 295-299. [CrossRef]

18. Fernandez, F.; Shridas, P.; Jiang, S.; Aebi, M.; Waechter, C.J. Expression and characterization of a human cDNA that complements the temperature-sensitive defect in dolichol kinase activity in the yeast sec59-1 mutant: The enzymatic phosphorylation of dolichol and diacylglycerol are catalyzed by separate CTP-mediated. Glycobiology 2002, 12, 555-562. [CrossRef] [PubMed]

19. Hong, Y.; Stanley, P. Lec3 Chinese Hamster Ovary Mutants Lack UDP-N-acetylglucosamine 2-Epimerase Activity because of Mutations in the Epimerase Domain of the Gne Gene. J. Biol. Chem. 2003, 278, 53045-53054. [CrossRef] [PubMed]

20. Maszczak-Seneczko, D.; Sosicka, P.; Majkowski, M.; Olczak, T.; Olczak, M. UDP-N-acetylglucosamine transporter and UDP-galactose transporter form heterologous complexes in the Golgi membrane. FEBS Lett. 2012, 586, 4082-4087. [CrossRef] [PubMed]

21. Maszczak-Seneczko, D.; Sosicka, P.; Kaczmarek, B.; Majkowski, M.; Luzarowski, M.; Olczak, T.; Olczak, M. UDP-galactose (SLC35A2) and UDP-N-acetylglucosamine (SLC35A3) transporters form glycosylation-related complexes with mannoside acetylglucosaminyltransferases (Mgats). J. Biol. Chem. 2015, 290, 15475-15486. [CrossRef] [PubMed]

22. Lübke, T.; Marquardt, T.; Etzioni, A.; Hartmann, E.; Von Figura, K.; Körner, C. Complementation cloning identifies CDG-IIc, a new type of congenital disorders of glycosylation, as a GDP-fucose transporter deficiency. Nat. Genet. 2001, 28, 73-76. [CrossRef] [PubMed]

23. Hidalgo, A. Insights into leukocyte adhesion deficiency type 2 from a novel mutation in the GDP-fucose transporter gene. Blood 2003, 101, 1705-1712. [CrossRef] [PubMed]

24. Grubenmann, C.E. Deficiency of the first mannosylation step in the $N$-glycosylation pathway causes congenital disorder of glycosylation type Ik. Hum. Mol. Genet. 2004, 13, 535-542. [CrossRef] [PubMed]

25. Martinez-Duncker, I.; Dupré, T.; Piller, V.; Piller, F.; Candelier, J.J.; Trichet, C.; Tchernia, G.; Oriol, R.; Mollicone, R. Genetic complementation reveals a novel human congenital disorder of glycosylation of type II, due to inactivation of the Golgi CMP-sialic acid transporter. Blood 2005, 105, 2671-2676. [CrossRef] [PubMed]

26. Shin, D.-J.; Kang, J.Y.; Kim, Y.U.; Yoon, J.S.; Choy, H.E.; Maeda, Y.; Kinoshita, T.; Hong, Y. Isolation of new $\mathrm{CHO}$ cell mutants defective in CMP-sialic acid biosynthesis and transport. Mol. Cells 2006, 22, 343-352. [PubMed]

27. Helmus, Y.; Denecke, J.; Yakubenia, S.; Robinson, P.; Lühn, K.; Watson, D.L.; McGrogan, P.J.; Vestweber, D.; Marquardt, T.; Wild, M.K. Leukocyte adhesion deficiency II patients with a dual defect of the GDP-fucose transporter. Blood 2006, 107, 3959-3966. [CrossRef] [PubMed]

28. Jay, C.; Nemunaitis, G.; Nemunaitis, J.; Senzer, N.; Hinderlich, S.; Darvish, D.; Ogden, J.; Eager, J.; Tong, A.; Maples, P.B. Preclinical assessment of wt GNE gene plasmid for management of hereditary inclusion body myopathy 2 (HIBM2). Gene Regul. Syst. Biol. 2008, 2008, 243-252. [CrossRef] 
29. Lefeber, D.J.; de Brouwer, A.P.M.; Morava, E.; Riemersma, M.; Schuurs-Hoeijmakers, J.H.M.; Absmanner, B.; Verrijp, K.; van den Akker, W.M.R.; Huijben, K.; Steenbergen, G.; et al. Autosomal recessive dilated cardiomyopathy due to DOLK mutations results from abnormal dystroglycan O-mannosylation. PLoS Genet. 2011, 7, e1002427. [CrossRef] [PubMed]

30. Rosnoblet, C.; Legrand, D.; Demaegd, D.; Hacine-Gherbi, H.; De Bettignies, G.; Bammens, R.; Borrego, C.; Duvet, S.; Morsomme, P.; Matthijs, G.; et al. Impact of disease-causing mutations on TMEM165 subcellular localization, a recently identified protein involved in CDG-II. Hum. Mol. Genet. 2013, 22, 2914-2928. [CrossRef] [PubMed]

31. Rohlfing, A.K.; Rust, S.; Reunert, J.; Tirre, M.; Du Chesne, I.; Wemhoff, S.; Meinhardt, F.; Hartmann, H.; Das, A.M.; Marquardt, T. ALG1-CDG: A new case with early fatal outcome. Gene 2014, 534, 345-351. [CrossRef] [PubMed]

32. Riemersma, M.; Froese, D.S.; Van Tol, W.; Engelke, U.F.; Kopec, J.; Van Scherpenzeel, M.; Ashikov, A.; Krojer, T.; Von Delft, F.; Tessari, M.; et al. Human ISPD Is a Cytidyltransferase Required for Dystroglycan O-Mannosylation. Chem. Biol. 2015, 22, 1643-1652. [CrossRef] [PubMed]

33. Dörre, K.; Olczak, M.; Wada, Y.; Sosicka, P.; Grüneberg, M.; Reunert, J.; Kurlemann, G.; Fiedler, B.; Biskup, S.; Hörtnagel, K.; et al. A new case of UDP-galactose transporter deficiency (SLC35A2-CDG): Molecular basis, clinical phenotype, and therapeutic approach. J. Inherit. Metab. Dis. 2015, 38, 931-940. [CrossRef] [PubMed]

34. Ng, B.G.; Shiryaev, S.A.; Rymen, D.; Eklund, E.A.; Raymond, K.; Kircher, M.; Abdenur, J.E.; Alehan, F.; Midro, A.T.; Bamshad, M.J.; et al. ALG1-CDG: Clinical and Molecular Characterization of 39 Unreported Patients. Hum. Mutat. 2016, 37, 653-660. [CrossRef] [PubMed]

35. Tanigawa, J.; Mimatsu, H.; Mizuno, S.; Okamoto, N.; Fukushi, D.; Tominaga, K.; Kidokoro, H.; Muramatsu, Y.; Nishi, E.; Nakamura, S.; et al. Phenotype-genotype correlations of PIGO deficiency with variable phenotypes from infantile lethality to mild learning difficulties. Hum. Mutat. 2017, 38, 805-815. [CrossRef] [PubMed]

36. Potelle, S.; Dulary, E.; Climer, L.; Duvet, S.; Morelle, W.; Vicogne, D.; Lebredonchel, E.; Houdou, M.; Spriet, C.; Krzewinski-Recchi, M.-A.; et al. Manganese-induced turnover of TMEM165. Biochem. J. 2017, 474, 1481-1493. [CrossRef] [PubMed]

37. Krawitz, P.M.; Murakami, Y.; Hecht, J.; Krüger, U.; Holder, S.E.; Mortier, G.R.; Delle Chiaie, B.; De Baere, E.; Thompson, M.D.; Roscioli, T.; et al. Mutations in PIGO, a member of the GPI-anchor-synthesis pathway, cause hyperphosphatasia with mental retardation. Am. J. Hum. Genet. 2012, 91, 146-151. [CrossRef] [PubMed]

38. Mohamed, M.; Guillard, M.; Schmidt, S.; Gerardy-schahn, R.; Deen, P.M.T.; Wevers, R.A.; Lefeber, D.J.; Morava, E. Intellectual disability and bleeding diathesis due to deficient CMP—Sialic acid transport. Neurology 2013, 81, 681-687. [CrossRef] [PubMed]

39. Grover, S.; Arya, R. Role of UDP-N-acetylglucosamine2-Epimerase/N-acetylmannosamine Kinase (GNE) in ß1-Integrin-Mediated Cell Adhesion. Mol. Neurobiol. 2014, 50, 257-273. [CrossRef] [PubMed]

40. Hinderlich, S.; Salama, I.; Eisenberg, I.; Potikha, T.; Mantey, L.R.; Yarema, K.J.; Horstkorte, R.; Argov, Z.; Sadeh, M.; Reutter, W.; et al. The homozygous M712T mutation of UDP-N-acetylglucosamine 2-epimerase/ $N$-acetylmannosamine kinase results in reduced enzyme activities but not in altered overall cellular sialylation in hereditary inclusion body myopathy. FEBS Lett. 2004, 566, 105-109. [CrossRef] [PubMed]

41. Janik, A.; Sosnowska, M.; Kruszewska, J.; Krotkiewski, H.; Lehle, L.; Palamarczyk, G. Overexpression of GDP-mannose pyrophosphorylase in Saccharomyces cerevisiae corrects defects in dolichol-linked saccharide formation and protein glycosylation. Biochim. Biophys. Acta Gen. Subj. 2003, 1621, 22-30. [CrossRef]

42. Stray-Pedersen, A.; Backe, P.H.; Sorte, H.S.; Mørkrid, L.; Chokshi, N.Y.; Erichsen, H.C.; Gambin, T.; Elgstøen, K.B.P.; Bjørås, M.; Wlodarski, M.W.; et al. PGM3 mutations cause a congenital disorder of glycosylation with severe immunodeficiency and skeletal dysplasia. Am. J. Hum. Genet. 2014, 95, 96-107. [CrossRef] [PubMed]

43. Lundin, K.E.; Hamasy, A.; Backe, P.H.; Moens, L.N.; Falk-Sörqvist, E.; Elgstøen, K.B.; Mørkrid, L.; Bjørås, M.; Granert, C.; Norlin, A.C.; et al. Susceptibility to infections, without concomitant hyper-IgE, reported in 1976, is caused by hypomorphic mutation in the phosphoglucomutase 3 (PGM3) gene. Clin. Immunol. 2015, 161, 366-372. [CrossRef] [PubMed]

44. Li, S.-T.; Wang, N.; Xu, S.; Yin, J.; Nakanishi, H.; Dean, N.; Gao, X.-D. Quantitative study of yeast Alg1 $\beta-1,4$ mannosyltransferase activity, a key enzyme involved in protein $\mathrm{N}$-glycosylation. Biochim. Biophys. Acta Gen. Subj. 2017, 1861, 2934-2941. [CrossRef] [PubMed] 
45. Seppala, R.; Tietze, F.; Krasnewich, D.; Weiss, P.; Ashwell, G.; Barsh, G.; Thomas, G.H.; Packman, S.; Gahl, W.A. Sialic acid metabolism in sialuria fibroblasts. J. Biol. Chem. 1991, 266, 7456-7461. [PubMed]

46. Panneerselvam, K.; Freeze, H.H. Mannose corrects altered N-glycosylation in carbohydrate-deficient glycoprotein syndrome fibroblasts. J. Clin. Investig. 1996, 97, 1478-1487. [CrossRef] [PubMed]

47. Panneerselvam, K.; Etchison, J.R.; Skovby, F.; Freeze, H.H. Abnormal metabolism of mannose in families with carbohydrate-deficient glycoprotein syndrome Type 1. Biochem. Mol. Med. 1997, 61, 161-167. [CrossRef] [PubMed]

48. Ohkura, T.; Fukushima, K.; Kurisaki, A.; Sagami, H.; Ogura, K.; Ohno, K.; Hara-Kuge, S.; Yamashita, K. A partial deficiency of dehydrodolichol reduction is a cause of carbohydrate-deficient glycoprotein syndrome type I. J. Biol. Chem. 1997, 272, 6868-6875. [CrossRef] [PubMed]

49. Niehues, R.; Hasilik, M.; Alton, G.; Körner, C.; Schiebe-Sukumar, M.; Koch, H.G.; Zimmer, K.P.; Wu, R.; Harms, E.; Reiter, K.; et al. Carbohydrate-deficient glycoprotein syndrome type Ib. Phosphomannose isomerase deficiency and mannose therapy. J. Clin. Investig. 1998, 101, 1414-1420. [CrossRef] [PubMed]

50. Karsan, A.; Cornejo, C.J.; Winn, R.K.; Schwartz, B.R.; Way, W.; Lannir, N.; Gershoni-Baruch, R.; Etzioni, A.; Ochs, H.D.; Harlan, J.M. Leukocyte adhesion deficiency type II is a generalized defect of de novo GDP-fucose biosynthesis: Endothelial cell fucosylation is not required for neutrophil rolling on human nonlymphoid endothelium. J. Clin. Investig. 1998, 101, 2438-2445. [CrossRef] [PubMed]

51. Lübke, T.; Marquardt, T.; Von Figura, K.; Körner, C. A new type of carbohydrate-deficient glycoprotein syndrome due to a decreased import of GDP-fucose into the Golgi. J. Biol. Chem. 1999, 274, 25986-25989. [CrossRef] [PubMed]

52. Rush, J.S.; Panneerselvam, K.; Waechter, C.J.; Freeze, H.H. Mannose supplementation corrects GDP-mannose deficiency in cultured fibroblasts from some patients with Congenital Disorders of Glycosylation (CDG). Glycobiology 2000, 10, 829-835. [CrossRef] [PubMed]

53. Marquardt, T.; Lühn, K.; Srikrishna, G.; Freeze, H.H.; Harms, E.; Vestweber, D. Correction of leukocyte adhesion deficiency type II with oral fucose. Blood 1999, 94, 3976-3985. [PubMed]

54. Lühn, K.; Wild, M.K.; Eckhardt, M.; Gerardy-Schahn, R.; Vestweber, D. The gene defective in leukocyte adhesion deficiency II encodes a putative GDP-fucose transporter. Nat. Genet. 2001, 28, 69-72. [CrossRef] [PubMed]

55. Sturla, L.; Puglielli, L.; Tonetti, M.; Berninsone, P.; Hirschberg, C.B.; de Flora, A.; Etzioni, A. Impairment of the Golgi GDP-L-fucose transport and unresponsiveness to fucose replacement therapy in LAD II patients. Pediatr. Res. 2001, 49, 537-542. [CrossRef] [PubMed]

56. Sparks, S.E.; Ciccone, C.; Lalor, M.; Orvisky, E.; Klootwijk, R.; Savelkoul, P.J.; Dalakas, M.C.; Krasnewich, D.M.; Gahl, W.A.; Huizing, M. Use of a cell-free system to determine UDP-N-acetylglucosamine 2-epimerase and $N$-acetylmannosamine kinase activities in human hereditary inclusion body myopathy. Glycobiology 2005, 15, 1102-1110. [CrossRef] [PubMed]

57. Almeida, A.M.; Murakami, Y.; Baker, A.; Maeda, Y.; Roberts, I.A.G.; Kinoshita, T.; Layton, D.M.; Karadimitris, A. Targeted Therapy for Inherited GPI Deficiency. N. Engl. J. Med. 2007, 356, 1641-1647. [CrossRef] [PubMed]

58. Lu, L.; Hou, X.; Shi, S.; Körner, C.; Stanley, P. Slc35c2 promotes Notch1 fucosylation and is required for optimal Notch signaling in mammalian cells. J. Biol. Chem. 2010, 285, 36245-36254. [CrossRef] [PubMed]

59. Sharma, V.; Ichikawa, M.; He, P.; Bravo, Y.; Dahl, R.; Ng, B.G.; Cosford, N.D.P.; Freeze, H.H. Phosphomannose isomerase inhibitors improve $\mathrm{N}$-glycosylation in selected phosphomannomutase-deficient fibroblasts. J. Biol. Chem. 2011, 286, 39431-39438. [CrossRef] [PubMed]

60. Li, F.-Y.; Lenardo, M.J.; Chaigne-Delalande, B. Loss of MAGT1 abrogates the $\mathrm{Mg}^{2+}$ flux required for T cell signaling and leads to a novel human primary immunodeficiency. Magnes. Res. 2011, 24, S109-S114. [CrossRef] [PubMed]

61. Mitrani-Rosenbaum, S.; Yakovlev, L.; Becker Cohen, M.; Telem, M.; Elbaz, M.; Yanay, N.; Yotvat, H.; Ben Shlomo, U.; Harazi, A.; Fellig, Y.; et al. Sustained expression and safety of human GNE in normal mice after gene transfer based on AAV8 systemic delivery. Neuromuscul. Disord. 2012, 22, 1015-1024. [CrossRef] [PubMed]

62. Li, H.; Chen, Q.; Liu, F.; Zhang, X.; Li, W.; Liu, S.; Zhao, Y.; Gong, Y.; Yan, C. Unfolded Protein Response and Activated Degradative Pathways Regulation in GNE Myopathy. PLoS ONE 2013, 8, e58116. [CrossRef] [PubMed]

63. Chaigne-Delalande, B.; Li, F.-Y.; O'Connor, G.M.; Lukacs, M.J.; Jiang, P.; Zheng, L.; Shatzer, A.; Biancalana, M.; Pittaluga, S.; Matthews, H.F.; et al. $\mathrm{Mg}^{2+}$ Regulates Cytotoxic Functions of NK and CD8 T Cells in Chronic EBV Infection Through NKG2D. Science 2013, 341, 186-191. [CrossRef] [PubMed] 
64. Costa, J.R.; Caputo, V.S.; Makarona, K.; Layton, D.M.; Roberts, I.A.G.; Almeida, A.M.; Karadimitris, A. Cell-type-specific transcriptional regulation of PIGM underpins the divergent hematologic phenotype in inherited GPl deficiency. Blood 2014, 124, 3151-3154. [CrossRef] [PubMed]

65. Tegtmeyer, L.C.; Rust, S.; van Scherpenzeel, M.; Ng, B.G.; Losfeld, M.-E.; Timal, S.; Raymond, K.; He, P.; Ichikawa, M.; Veltman, J.; et al. Multiple Phenotypes in Phosphoglucomutase 1 Deficiency. N. Engl. J. Med. 2014, 370, 533-542. [CrossRef] [PubMed]

66. Patzel, K.A.; Yardeni, T.; Le Poëc-Celic, E.; Leoyklang, P.; Dorward, H.; Alonzi, D.S.; Kukushkin, N.V.; Xu, B.; Zhang, Y.; Sollogoub, M.; et al. Non-specific accumulation of glycosphingolipids in GNE myopathy. J. Inherit. Metab. Dis. 2014, 37, 297-308. [CrossRef] [PubMed]

67. Zhang, Y.; Yu, X.; Ichikawa, M.; Lyons, J.J.; Datta, S.; Lamborn, I.T.; Jing, H.; Kim, E.S.; Biancalana, M.; Wolfe, L.A.; et al. Autosomal recessive phosphoglucomutase 3 (PGM3) mutations link glycosylation defects to atopy, immune deficiency, autoimmunity, and neurocognitive impairment. J. Allergy Clin. Immunol. 2014, 133, 1400-1409.e5. [CrossRef] [PubMed]

68. Gerin, I.; Ury, B.; Breloy, I.; Bouchet-Seraphin, C.; Bolsée, J.; Halbout, M.; Graff, J.; Vertommen, D.; Muccioli, G.G.; Seta, N.; et al. ISPD produces CDP-ribitol used by FKTN and FKRP to transfer ribitol phosphate onto $\alpha$-dystroglycan. Nat. Commun. 2016, 7. [CrossRef] [PubMed]

69. Koch, J.; Mayr, J.A.; Alhaddad, B.; Rauscher, C.; Bierau, J.; Kovacs-Nagy, R.; Coene, K.L.M.; Bader, I.; Holzhacker, M.; Prokisch, H.; et al. CAD mutations and uridine-responsive epileptic encephalopathy. Brain 2017, 140, 279-286. [CrossRef] [PubMed]

70. Morelle, W.; Potelle, S.; Witters, P.; Wong, S.; Climer, L.; Lupashin, V.; Matthijs, G.; Gadomski, T.; Jaeken, J.; Cassiman, D.; et al. Galactose supplementation in patients with TMEM165-CDG rescues the glycosylation defects. J. Clin. Endocrinol. Metab. 2017, 102, 1375-1386. [CrossRef] [PubMed]

71. Ng, B.G.; Asteggiano, C.G.; Kircher, M.; Buckingham, K.J.; Raymond, K.; Nickerson, D.A.; Shendure, J.; Bamshad, M.J.; Ensslen, M.; Freeze, H.H. Encephalopathy caused by novel mutations in the CMP-sialic acid transporter, SLC35A1. Am. J. Med. Genet. Part A 2017, 173, 2906-2911. [CrossRef] [PubMed]

72. Sharma, V.; Nayak, J.; DeRossi, C.; Charbono, A.; Ichikawa, M.; Ng, B.G.; Grajales-Esquivel, E.; Srivastava, A.; Wang, L.; He, P.; et al. Mannose supplements induce embryonic lethality and blindness in phosphomannose isomerase hypomorphic mice. FASEB J. 2014, 28, 1854-1869. [CrossRef] [PubMed]

73. Ahmad, G.; Amiji, M. Use of CRISPR/ Cas9 gene-editing tools for developing models in drug discovery. Drug Discov. Today 2018. [CrossRef] [PubMed]

74. Schwarzkopf, M.; Knobeloch, K.-P.; Rohde, E.; Hinderlich, S.; Wiechens, N.; Lucka, L.; Horak, I.; Reutter, W.; Horstkorte, R. Sialylation is essential for early development in mice. Proc. Natl. Acad. Sci. USA 2002, 99, 5267-5270. [CrossRef] [PubMed]

75. Thiel, C.; Lubke, T.; Matthijs, G.; von Figura, K.; Korner, C. Targeted Disruption of the Mouse Phosphomannomutase 2 Gene Causes Early Embryonic Lethality. Mol. Cell. Biol. 2006, 26, 5615-5620. [CrossRef] [PubMed]

76. Sela, I.; Yakovlev, L.; Becker Cohen, M.; Elbaz, M.; Yanay, N.; Ben Shlomo, U.; Yotvat, H.; Fellig, Y.; Argov, Z.; Mitrani-Rosenbaum, S. Variable phenotypes of knockin mice carrying the M712T Gne mutation. NeuroMol. Med. 2013, 15, 180-191. [CrossRef] [PubMed]

77. Schneider, A.; Thiel, C.; Rindermann, J.; Derossi, C.; Popovici, D.; Hoffmann, G.F.; Gröne, H.J.; Körner, C. Successful prenatal mannose treatment for congenital disorder of glycosylation-Ia in mice. Nat. Med. 2012, 18, 71-73. [CrossRef] [PubMed]

78. Niethamer, T.K.; Yardeni, T.; Leoyklang, P.; Ciccone, C.; Astiz-Martinez, A.; Jacobs, K.; Dorward, H.M.; Zerfas, P.M.; Gahl, W.A.; Huizing, M. Oral monosaccharide therapies to reverse renal and muscle hyposialylation in a mouse model of GNE myopathy. Mol. Genet. Metab. 2012, 107, 748-755. [CrossRef] [PubMed]

79. Ito, M.; Sugihara, K.; Asaka, T.; Toyama, T.; Yoshihara, T.; Furuichi, K.; Wada, T.; Asano, M. Glycoprotein hyposialylation gives rise to a nephrotic-like syndrome that is prevented by sialic acid administration in GNE V572L point-mutant mice. PLoS ONE 2012, 7. [CrossRef] [PubMed]

80. Yardeni, T.; Jacobs, K.; Niethamer, T.K.; Ciccone, C.; Anikster, Y.; Kurochkina, N.; Gahl, W.A.; Huizing, M. Murine isoforms of UDP-GlcNAc 2-epimerase/ManNAc kinase: Secondary structures, expression profiles, and response to ManNAc therapy. Glycoconj. J. 2013, 30, 609-618. [CrossRef] [PubMed] 
81. Galeano, B.; Klootwijk, R.; Manoli, I.; Sun, M.; Ciccone, C.; Darvish, D.; Starost, M.F.; Zerfas, P.M.; Hoffmann, V.J.; Hoogstraten-Miller, S.; et al. Mutation in the key enzyme of sialic acid biosynthesis causes severe glomerular proteinuria and is rescued by $N$-acetylmannosamine. J. Clin. Investig. 2007, 117, 1585-1594. [CrossRef] [PubMed]

82. Malicdan, M.C.V.; Noguchi, S.; Hayashi, Y.K.; Nonaka, I.; Nishino, I. Prophylactic treatment with sialic acid metabolites precludes the development of the myopathic phenotype in the DMRV-hIBM mouse model. Nat. Med. 2009, 15, 690-695. [CrossRef] [PubMed]

83. Malicdan, M.C.V.; Noguchi, S.; Tokutomi, T.; Goto, Y.I.; Nonaka, I.; Hayashi, Y.K.; Nishino, I. Peracetylated $\mathrm{N}$-acetylmannosamine, a synthetic sugar molecule, efficiently rescues muscle phenotype and biochemical defects in mouse model of sialic acid-deficient myopathy. J. Biol. Chem. 2012, 287, 2689-2705. [CrossRef] [PubMed]

84. Yonekawa, T.; Malicdan, M.C.V.; Cho, A.; Hayashi, Y.K.; Nonaka, I.; Mine, T.; Yamamoto, T.; Nishino, I.; Noguchi, S. Sialyllactose ameliorates myopathic phenotypes in symptomatic GNE myopathy model mice. Brain 2014, 137, 2670-2679. [CrossRef] [PubMed]

85. Dickinson, M.E.; Flenniken, A.M.; Ji, X.; Teboul, L.; Wong, M.D.; White, J.K.; Meehan, T.F.; Weninger, W.J.; Westerberg, H.; Adissu, H.; et al. High-throughput discovery of novel developmental phenotypes. Nature 2016, 537, 508-514. [CrossRef] [PubMed]

86. The Jackson Laboratory. Available online: https:/ /www.jax.org/ (accessed on 18 January 2018).

87. Runge, K.W.; Huffaker, T.C.; Robbins, P.W. Two yeast mutations in glucosylation steps of the asparagine glycosylation pathway. J. Biol. Chem. 1984, 259, 412-417. [PubMed]

88. Uchimura, S.; Sugiyama, M.; Nikawa, J. Effects of N-glycosylation and Inositol on the ER Stress Response in Yeast Saccharomyces cerevisiae. Biosci. Biotechnol. Biochem. 2005, 69, 1274-1280. [CrossRef] [PubMed]

89. Shrimal, S.; Gilmore, R. Reduced expression of the oligosaccharyltransferase exacerbates protein hypoglycosylation in cells lacking the fully assembled oligosaccharide donor. Glycobiology 2015, 25, 774-783. [CrossRef] [PubMed]

90. Zhou, H.; Clapham, D.E. Mammalian MagT1 and TUSC3 are required for cellular magnesium uptake and vertebrate embryonic development. Proc. Natl. Acad. Sci. USA 2009, 106, 15750-15755. [CrossRef] [PubMed]

91. DeRossi, C.; Bode, L.; Eklund, E.A.; Zhang, F.; Davis, J.A.; Westphal, V.; Wang, L.; Borowsky, A.D.; Freeze, H.H. Ablation of mouse phosphomannose isomerase (Mpi) causes mannose 6-phosphate accumulation, toxicity, and embryonic lethality. J. Biol. Chem. 2006, 281, 5916-5927. [CrossRef] [PubMed]

92. Chu, J.; Mir, A.; Gao, N.; Rosa, S.; Monson, C.; Sharma, V.; Steet, R.; Freeze, H.H.; Lehrman, M.A.; Sadler, K.C. A zebrafish model of congenital disorders of glycosylation with phosphomannose isomerase deficiency reveals an early opportunity for corrective mannose supplementation. Dis. Model. Mech. 2013, 6, 95-105. [CrossRef] [PubMed]

93. Thiesler, C.T.; Cajic, S.; Hoffmann, D.; Thiel, C.; van Diepen, L.; Hennig, R.; Sgodda, M.; Weißmann, R.; Reichl, U.; Steinemann, D.; et al. Glycomic Characterization of Induced Pluripotent Stem Cells Derived from a Patient Suffering from Phosphomannomutase 2 Congenital Disorder of Glycosylation (PMM2-CDG). Mol. Cell. Proteom. 2016, 15, 1435-1452. [CrossRef] [PubMed]

94. Chan, B.; Clasquin, M.; Smolen, G.A.; Histen, G.; Powe, J.; Chen, Y.; Lin, Z.; Lu, C.; Liu, Y.; Cang, Y.; et al. A mouse model of a human congenital disorder of glycosylation caused by loss of PMM2. Hum. Mol. Genet. 2016, 25, 2182-2193. [CrossRef] [PubMed]

95. Cline, A.; Gao, N.; Flanagan-Steet, H.; Sharma, V.; Rosa, S.; Sonon, R.; Azadi, P.; Sadler, K.C.; Freeze, H.H.; Lehrman, M.A.; et al. A zebrafish model of PMM2-CDG reveals altered neurogenesis and a substrate-accumulation mechanism for N-linked glycosylation deficiency. Mol. Biol. Cell 2012, 23, 4175-4187. [CrossRef] [PubMed]

96. Parkinson, W.M.; Dookwah, M.; Dear, M.L.; Gatto, C.L.; Aoki, K.; Tiemeyer, M.; Broadie, K. Synaptic roles for phosphomannomutase type 2 in a new Drosophila congenital disorder of glycosylation disease model. Dis. Model. Mech. 2016, 9, 513-527. [CrossRef] [PubMed]

97. Jansen, E.J.R.; Timal, S.; Ryan, M.; Ashikov, A.; Van Scherpenzeel, M.; Graham, L.A.; Mandel, H.; Hoischen, A.; Iancu, T.C.; Raymond, K.; et al. ATP6AP1 deficiency causes an immunodeficiency with hepatopathy, cognitive impairment and abnormal protein glycosylation. Nat. Commun. 2016, 7. [CrossRef] [PubMed]

98. Gokey, J.J.; Dasgupta, A.; Amack, J.D. The V-ATPase accessory protein Atp6ap1b mediates dorsal forerunner cell proliferation and left-right asymmetry in zebrafish. Dev. Biol. 2015, 407, 115-130. [CrossRef] [PubMed] 
99. Schoonderwoert, V.T.G.; Martens, G.J.M. Targeted disruption of the mouse gene encoding the V-ATPase accessory subunit Ac45. Mol. Membr. Biol. 2002, 19, 67-71. [CrossRef] [PubMed]

100. Ng, B.G.; Wolfe, L.A.; Ichikawa, M.; Markello, T.; He, M.; Tifft, C.J.; Gahl, W.A.; Freeze, H.H. Biallelic mutations in CAD, impair de novo pyrimidine biosynthesis and decrease glycosylation precursors. Hum. Mol. Genet. 2015, 24, 3050-3057. [CrossRef] [PubMed]

101. Franks, D.M.; Izumikawa, T.; Kitagawa, H.; Sugahara, K.; Okkema, P.G.C. elegans pharyngeal morphogenesis requires both de novo synthesis of pyrimidines and synthesis of heparan sulfate proteoglycans. Dev. Biol. 2006, 296, 409-420. [CrossRef] [PubMed]

102. Norby, S. A specific nutritional requirement for pyrimidines in rudimentary mutants of Drosophila melanogaster. Hereditas 1970, 66, 205-214. [CrossRef] [PubMed]

103. Willer, G.B.; Lee, V.M.; Gregg, R.G.; Link, B.A. Analysis of the zebrafish perplexed mutation reveals tissue-specific roles for de novo pyrimidine synthesis during development. Genetics 2005, 170, 1827-1837. [CrossRef] [PubMed]

104. Cox, J.A.; LaMora, A.; Johnson, S.L.; Voigt, M.M. Novel role for carbamoyl phosphate synthetase 2 in cranial sensory circuit formation. Int. J. Dev. Neurosci. 2014, 33, 41-48. [CrossRef] [PubMed]

105. Hill, K.J.; Stevens, T.H. Vma22p is a novel endoplasmic reticulum-associated protein required for assembly o fthe yeast vacuolar H(+)-ATPase complex. J. Biol. Chem. 1995, 270, 22329-22336. [CrossRef] [PubMed]

106. Miles, A.L.; Burr, S.P.; Grice, G.L.; Nathan, J.A. The vacuolar-ATPase complex and assembly factors, TMEM199 and CCDC115, control HIF1 $\alpha$ prolyl hydroxylation by regulating cellular Iron levels. eLife 2017, 6, 1-28. [CrossRef] [PubMed]

107. Bork, K.; Reutter, W.; Weidemann, W.; Horstkorte, R. Enhanced sialylation of EPO by overexpression of UDP-GlcNAc 2-epimerase/ManAc kinase containing a sialuria mutation in CHO cells. FEBS Lett. 2007, 581, 4195-4198. [CrossRef] [PubMed]

108. Son, Y.D.; Jeong, Y.T.; Park, S.Y.; Kim, J.H. Enhanced sialylation of recombinant human erythropoietin in Chinese hamster ovary cells by combinatorial engineering of selected genes. Glycobiology 2011, 21, 1019-1028. [CrossRef] [PubMed]

109. Möller, H.; Böhrsch, V.; Lucka, L.; Hackenberger, C.P.R.; Hinderlich, S. Efficient metabolic oligosaccharide engineering of glycoproteins by UDP- $N$-acetylglucosamine 2-epimerase/ $\mathrm{N}$-acetylmannosamine kinase (GNE) knock-down. Mol. Biosyst. 2011, 7, 2245-2251. [CrossRef] [PubMed]

110. Keppler, O.T.; Hinderlich, S.; Langner, J.; Schwartz-Albiez, R.; Reutter, W.; Pawlita, M. UDP-GlcNAc 2-Epimerase: A regulator of cell surface sialylation. Science 1999, 284, 1372-1376. [CrossRef] [PubMed]

111. Mantey, L.R.; Keppler, O.T.; Pawlita, M.; Reutter, W.; Hinderlich, S. Efficient biochemical engineering of cellular sialic acids using an unphysiological sialic acid precursor in cells lacking UDP-N-acetylglucosamine 2-epimerase. FEBS Lett. 2001, 503, 80-84. [CrossRef]

112. Krause, S.; Hinderlich, S.; Amsili, S.; Horstkorte, R.; Wiendl, H.; Argov, Z.; Mitrani-Rosenbaum, S.; Lochmüller, H. Localization of UDP-GlcNAc 2-epimerase/ManAc kinase (GNE) in the Golgi complex and the nucleus of mammalian cells. Exp. Cell Res. 2005, 304, 365-379. [CrossRef] [PubMed]

113. Weidemann, W.; Klukas, C.; Klein, A.; Simm, A.; Schreiber, F.; Horstkorte, R. Lessons from GNE-deficient embryonic stem cells: Sialic acid biosynthesis is involved in proliferation and gene expression. Glycobiology 2010, 20, 107-117. [CrossRef] [PubMed]

114. Milman Krentsis, I.; Sela, I.; Eiges, R.; Blanchard, V.; Berger, M.; Becker Cohen, M.; Mitrani-Rosenbaum, S. GNE is involved in the early development of skeletal and cardiac muscle. PLoS ONE 2011, 6. [CrossRef] [PubMed]

115. Weidemann, W.; Hering, J.; Bennmann, D.; Thate, A.; Horstkorte, R. The key enzyme of the sialic acid metabolism is involved in embryoid body formation and expression of marker genes of germ layer formation. Int. J. Mol. Sci. 2013, 14, 20555-20563. [CrossRef] [PubMed]

116. Gagiannis, D.; Orthmann, A.; Danßmann, I.; Schwarzkopf, M.; Weidemann, W.; Horstkorte, R. Reduced sialylation status in UDP- $N$-acetylglucosamine-2-epimerase/ $N$-acetylmannosamine kinase (GNE)-deficient mice. Glycoconj. J. 2007, 24, 125-130. [CrossRef] [PubMed]

117. Kakani, S.; Yardeni, T.; Poling, J.; Ciccone, C.; Niethamer, T.; Klootwijk, E.D.; Manoli, I.; Darvish, D.; Hoogstraten-Miller, S.; Zerfas, P.; et al. The Gne M712T mouse as a model for human glomerulopathy. Am. J. Pathol. 2012, 180, 1431-1440. [CrossRef] [PubMed] 
118. Malicdan, M.C.V.; Noguchi, S.; Nonaka, I.; Hayashi, Y.K.; Nishino, I. A Gne knockout mouse expressing human GNE D176V mutation develops features similar to distal myopathy with rimmed vacuoles or hereditary inclusion body myopathy. Hum. Mol. Genet. 2007, 16, 2669-2682. [CrossRef] [PubMed]

119. Anada, R.P.; Wong, K.T.; Malicdan, M.C.; Goh, K.J.; Hayashi, Y.; Nishino, I.; Noguchi, S. Absence of $\beta$-amyloid deposition in the central nervous system of a transgenic mouse model of distal myopathy with rimmed vacuoles. Amyloid 2014, 21, 138-139. [CrossRef] [PubMed]

120. Kreuzmann, D.; Horstkorte, R.; Kohla, G.; Kannicht, C.; Bennmann, D.; Thate, A.; Bork, K. Increased Polysialylation of the Neural Cell Adhesion Molecule in a Transgenic Mouse Model of Sialuria. ChemBioChem 2017, 18, 1188-1193. [CrossRef] [PubMed]

121. Daya, A.; Vatine, G.D.; Becker-Cohen, M.; Tal-Goldberg, T.; Friedmann, A.; Gothilf, Y.; Du, S.J.; Mitrani-Rosenbaum, S. Gne depletion during zebrafish development impairs skeletal muscle structure and function. Hum. Mol. Genet. 2014, 23, 3350-3361. [CrossRef] [PubMed]

122. Van Karnebeek, C.D.M.; Bonafé, L.; Wen, X.Y.; Tarailo-Graovac, M.; Balzano, S.; Royer-Bertrand, B.; Ashikov, A.; Garavelli, L.; Mammi, I.; Turolla, L.; et al. NANS-mediated synthesis of sialic acid is required for brain and skeletal development. Nat. Genet. 2016, 48, 777-784. [CrossRef] [PubMed]

123. Arimura, T.; Inagaki, N.; Hayashi, T.; Shichi, D.; Sato, A.; Hinohara, K.; Vatta, M.; Towbin, J.A.; Chikamori, T.; Yamashina, A.; et al. Impaired binding of ZASP/Cypher with phosphoglucomutase 1 is associated with dilated cardiomyopathy. Cardiovasc. Res. 2009, 83, 80-88. [CrossRef] [PubMed]

124. Greig, K.T.; Antonchuk, J.; Metcalf, D.; Morgan, P.O.; Krebs, D.L.; Zhang, J.-G.; Hacking, D.F.; Bode, L.; Robb, L.; Kranz, C.; et al. Agm1/Pgm3-Mediated Sugar Nucleotide Synthesis Is Essential for Hematopoiesis and Development. Mol. Cell. Biol. 2007, 27, 5849-5859. [CrossRef] [PubMed]

125. Patnaik, S.K.; Stanley, P. Mouse large can modify complex $N$ - and mucin $O$-glycans on $\alpha$-dystroglycan to induce laminin binding. J. Biol. Chem. 2005, 280, 20851-20859. [CrossRef] [PubMed]

126. Lim, S.F.; Lee, M.M.; Zhang, P.; Song, Z. The golgi CMP-sialic acid transporter: A new CHO mutant provides functional insights. Glycobiology 2008, 18, 851-860. [CrossRef] [PubMed]

127. Cipollo, J.F.; Awad, A.M.; Costello, C.E.; Hirschberg, C.B. srf-3, a mutant of Caenorhabditis elegans, resistant to bacterial infection and to biofilm binding, is deficient in glycoconjugates. J. Biol. Chem. 2004, 279, 52893-52903. [CrossRef] [PubMed]

128. Zhang, P.; Haryadi, R.; Chan, K.F.; Teo, G.; Goh, J.; Pereira, N.A.; Feng, H.; Song, Z. Identification of functional elements of the GDP-fucose transporter SLC35C1 using a novel Chinese hamster ovary mutant. Glycobiology 2012, 22, 897-911. [CrossRef] [PubMed]

129. Haryadi, R.; Zhang, P.; Chan, K.F.; Song, Z. CHO-gmt5, a novel CHO glycosylation mutant for producing afucosylated and asialylated recombinant antibodies. Bioengineered 2013, 4. [CrossRef] [PubMed]

130. Chan, K.F.; Shahreel, W.; Wan, C.; Teo, G.; Hayati, N.; Tay, S.J.; Tong, W.H.; Yang, Y.; Rudd, P.M.; Zhang, P.; et al. Inactivation of GDP-fucose transporter gene (Slc35c1) in CHO cells by ZFNs, TALENs and CRISPR-Cas9 for production of fucose-free antibodies. Biotechnol. J. 2016, 11, 399-414. [CrossRef] [PubMed]

131. Stadlmann, J.; Taubenschmid, J.; Wenzel, D.; Gattinger, A.; Dürnberger, G.; Dusberger, F.; Elling, U.; Mach, L.; Mechtler, K.; Penninger, J.M. Comparative glycoproteomics of stem cells identifies new players in ricin toxicity. Nature 2017, 549, 538-542. [CrossRef] [PubMed]

132. Hellbusch, C.C.; Sperandio, M.; Frommhold, D.; Yakubenia, S.; Wild, M.K.; Popovici, D.; Vestweber, D.; Gröne, H.J.; Von Figura, K.; Lübke, T.; et al. Golgi GDP-fucose transporter-deficient mice mimic congenital disorder of glycosylation IIc/leukocyte adhesion deficiency II. J. Biol. Chem. 2007, 282, 10762-10772. [CrossRef] [PubMed]

133. Yakubenia, S.; Frommhold, D.; Schölch, D.; Hellbusch, C.C.; Körner, C.; Petri, B.; Jones, C.; Ipe, U.; Bixel, M.G.; Krempien, R.; et al. Leukocyte trafficking in a mouse model for leukocyte adhesion deficiency II/congenital disorder of glycosylation IIc. Blood 2008, 112, 1472-1481. [CrossRef] [PubMed]

134. Rabionet, M.; Van Der Spoel, A.C.; Chuang, C.C.; Von Tümpling-Radosta, B.; Litjens, M.; Bouwmeester, D.; Hellbusch, C.C.; Körner, C.; Wiegandt, H.; Gorgas, K.; et al. Male germ cells require polyenoic sphingolipids with complex glycosylation for completion of meiosis: A link to ceramide synthase-3. J. Biol. Chem. 2008, 283, 13357-13369. [CrossRef] [PubMed]

135. Panzer, J.A.; Gibbs, S.M.; Dosch, R.; Wagner, D.; Mullins, M.C.; Granato, M.; Balice-Gordon, R.J. Neuromuscular synaptogenesis in wild-type and mutant zebrafish. Dev. Biol. 2005, 285, 340-357. [CrossRef] [PubMed] 
136. Song, Y.; Willer, J.R.; Scherer, P.C.; Panzer, J.A.; Kugath, A.; Skordalakes, E.; Gregg, R.G.; Willer, G.B.; Balice-Gordon, R.J. Neural and synaptic defects in slytherin, a zebrafish model for human congenital disorders of glycosylation. PLoS ONE 2010, 5. [CrossRef] [PubMed]

137. Feng, L.; Jiang, H.; Wu, P.; Marlow, F.L. Negative feedback regulation of Wnt signaling via N-linked fucosylation in zebrafish. Dev. Biol. 2014, 395, 268-286. [CrossRef] [PubMed]

138. Wang, B.; He, L.; Dong, H.; Dalton, T.P.; Nebert, D.W. Generation of a Slc39a8 Hypomorph Mouse: Markedly Decreased ZIP8 Zn ${ }^{2+} /\left(\mathrm{HCO}^{3-}\right) 2$ Transporter Expression. Biochem. Biophys. Res. Commun. 2011, 410, $289-294$. [CrossRef] [PubMed]

139. Gálvez-Peralta, M.; He, L.; Jorge-Nebert, L.F.; Wang, B.; Miller, M.L.; Eppert, B.L.; Afton, S.; Nebert, D.W. Zip8 zinc transporter: Indispensable role for both multiple-organ organogenesis and hematopoiesis in utero. PLoS ONE 2012, 7, 1-15. [CrossRef] [PubMed]

140. Cantagrel, V.; Lefeber, D.J.; Ng, B.G.; Guan, Z.; Silhavy, J.L.; Bielas, S.L.; Lehle, L.; Hombauer, H.; Adamowicz, M.; Swiezewska, E.; et al. SRD5A3 Is Required for Converting Polyprenol to Dolichol and Is Mutated in a Congenital Glycosylation Disorder. Cell 2010, 142, 203-217. [CrossRef] [PubMed]

141. Colinet, A.S.; Sengottaiyan, P.; Deschamps, A.; Colsoul, M.L.; Thines, L.; Demaegd, D.; Duchêne, M.C.; Foulquier, F.; Hols, P.; Morsomme, P. Yeast Gdt1 is a Golgi-localized calcium transporter required for stress-induced calcium signaling and protein glycosylation. Sci. Rep. 2016, 6, 24282. [CrossRef] [PubMed]

142. Potelle, S.; Morelle, W.; Dulary, E.; Duvet, S.; Vicogne, D.; Spriet, C.; Krzewinski-Recchi, M.A.; Morsomme, P.; Jaeken, J.; Matthijs, G.; et al. Glycosylation abnormalities in Gdt1p/TMEM165 deficient cells result from a defect in Golgi manganese homeostasis. Hum. Mol. Genet. 2016, 25, 1489-1500. [CrossRef] [PubMed]

143. Bammens, R.; Mehta, N.; Race, V.; Foulquier, F.; Jaeken, J.; Tiemeyer, M.; Steet, R.; Matthijs, G.; Flanagan-Steet, H. Abnormal cartilage development and altered N-glycosylation in Tmem165-deficient zebrafish mirrors the phenotypes associated with TMEM165-CDG. Glycobiology 2014, 25, 669-682. [CrossRef] [PubMed]

144. Jackson, D.D.; Stevens, T.H. VMA12 encodes a yeast endoplasmic reticulum protein required for vacuolar H+-ATPase assembly. J. Biol. Chem. 1997, 272, 25928-25934. [CrossRef] [PubMed]

145. Yuan, X.; Li, Z.; Baines, A.C.; Gavriilaki, E.; Ye, Z.; Wen, Z.; Braunstein, E.M.; Biesecker, L.G.; Cheng, L.; Dong, X.; et al. A hypomorphic PIGA gene mutation causes severe defects in neuron development and susceptibility to complement-mediated toxicity in a human iPSC model. PLoS ONE 2017, 12, e0174074. [CrossRef] [PubMed]

146. Kawagoe, K.; Kitamura, D.; Okabe, M.; Taniuchi, I.; Ikawa, M.; Watanabe, T.; Kinoshita, T.; Takeda, J. Glycosylphosphatidylinositol-anchor-deficient mice: Implications for clonal dominance of mutant cells in paroxysmal nocturnal hemoglobinuria. Blood 1996, 87, 3600-3606. [PubMed]

147. Tremml, G.; Dominguez, C.; Rosti, V.; Zhang, Z.; Pandolfi, P.P.; Keller, P.; Bessler, M. Increased sensitivity to complement and a decreased red blood cell life span in mice mosaic for a nonfunctional Piga gene. Blood 1999, 94, 2945-2954. [PubMed]

148. Kim, Y.U.; Hong, Y. Functional analysis of the first mannosyltransferase (PIG-M) involved in glycosylphosphatidylinositol synthesis in Plasmodium falciparum. Mol. Cells 2007, 24, 294-300. [PubMed]

149. Kim, Y.U.; Ashida, H.; Mori, K.; Maeda, Y.; Hong, Y.; Kinoshita, T. Both mammalian PIG-M and PIG-X are required for growth of GPI14-disrupted yeast. J. Biochem. 2007, 142, 123-129. [CrossRef] [PubMed]

150. Kanagawa, M.; Kobayashi, K.; Tajiri, M.; Manya, H.; Kuga, A.; Yamaguchi, Y.; Akasaka-Manya, K.; Furukawa, J.I.; Mizuno, M.; Kawakami, H.; Shinohara, Y.; et al. Identification of a Post-translational Modification with Ribitol-Phosphate and Its Defect in Muscular Dystrophy. Cell Rep. 2016, 14, $2209-2223$. [CrossRef] [PubMed]

151. Wright, K.M.; Lyon, K.A.; Leung, H.; Leahy, D.J.; Ma, L.; Ginty, D.D. Dystroglycan Organizes Axon Guidance Cue Localization and Axonal Pathfinding. Neuron 2012, 76, 931-944. [CrossRef] [PubMed]

152. Lee, A.Y.; Lloyd, K.C.K. Conditional targeting of Ispd using paired Cas9 nickase and a single DNA template in mice. FEBS Open Bio 2014, 4, 637-642. [CrossRef] [PubMed]

153. Roscioli, T.; Kamsteeg, E.; Buysse, K.; Maystadt, I.; van Reeuwijk, J.; van den Elzen, C.; van Beusekom, E.; Riemersma, M.; Pfundt, R.; Vissers, L.E.L.M.; et al. Mutations in ISPD cause Walker-Warburg syndrome and defective glycosylation of $\alpha$-dystroglycan. Nat. Genet. 2012, 44, 581-585. [CrossRef] [PubMed] 
154. Zühlsdorf, A.; Park, J.H.; Wada, Y.; Rust, S.; Reunert, J.; DuChesne, I.; Grüneberg, M.; Marquardt, T. Transferrin variants: Pitfalls in the diagnostics of Congenital disorders of glycosylation. Clin. Biochem. 2015, 48, 11-13. [CrossRef] [PubMed]

155. Heywood, W.E.; Bliss, E.; Mills, P.; Yuzugulen, J.; Carreno, G.; Clayton, P.T.; Muntoni, F.; Worthington, V.C.; Torelli, S.; Sebire, N.J.; et al. Global serum glycoform profiling for the investigation of dystroglycanopathies \& Congenital Disorders of Glycosylation. Mol. Genet. Metab. Rep. 2016, 7, 55-62. [CrossRef] [PubMed]

156. Pérez-Cerdá, C.; Quelhas, D.; Vega, A.I.; Ecay, J.; Vilarinho, L.; Ugarte, M. Screening using serum percentage of carbohydrate-deficient transferrin for congenital disorders of glycosylation in children with suspected metabolic disease. Clin. Chem. 2008, 54, 93-100. [CrossRef] [PubMed]

157. Wopereis, S.; Grünewald, S.; Morava, É.; Penzien, J.M.; Briones, P.; García-Silva, M.T.; Demacker, P.N.M.; Huijben, K.M.L.C.; Wevers, R.A. Apolipoprotein C-III Isofocusing in the Diagnosis of Genetic Defects in O-Glycan Biosynthesis. Clin. Chem. 2003, 49, 1839-1845. [CrossRef] [PubMed]

158. Daci, A.; Bozalija, A.; Jashari, F.; Krasniqi, S. Individualizing Treatment Approaches for Epileptic Patients with Glucose Transporter Type1 (GLUT-1) Deficiency. Int. J. Mol. Sci. 2018, 19, 122. [CrossRef] [PubMed]

159. Coelho, A.I.; Rubio-Gozalbo, M.E.; Vicente, J.B.; Rivera, I. Sweet and sour: An update on classic galactosemia. J. Inherit. Metab. Dis. 2017, 40, 325-342. [CrossRef] [PubMed]

160. Babovic-Vuksanovic, D.; Patterson, M.C.; Schwenk, W.F.; O’Brien, J.F.; Vockley, J.; Freeze, H.H.; Mehta, D.P.; Michels, V.V. Severe hypoglycemia as a presenting symptom of carbohydrate-deficient glycoprotein syndrome. J. Pediatr. 1999, 135, 775-781. [CrossRef]

161. Hendriksz, C.J.; McClean, P.; Henderson, M.J.; Keir, D.G.; Worthington, V.C.; Imtiaz, F.; Schollen, E.; Matthijs, B.G.; Winchester, G. Successful treatment of carbohydrate deficient glycoprotein syndrome type $1 \mathrm{~b}$ with oral mannose. Arch. Dis. Child. 2001, 85, 339-340. [CrossRef] [PubMed]

162. Westphal, V.; Kjaergaard, S.; Davis, J.A.; Peterson, S.M.; Skovby, F.; Freeze, H.H. Genetic and metabolic analysis of the first adult with congenital disorder of glycosylation type Ib: Long-term outcome and effects of mannose supplementation. Mol. Genet. Metab. 2001, 73, 77-85. [CrossRef] [PubMed]

163. Harms, H.K.; Zimmer, K.P.; Kurnik, K.; Bertele-Harms, R.M.; Weidinger, S.; Reiter, K. Oral mannose therapy persistently corrects the severe clinical symptoms and biochemical abnormalities of phosphomannose isomerase deficiency. Acta Paediatr. Int. J. Paediatr. 2002, 91, 1065-1072. [CrossRef]

164. Penel-Capelle, D.; Dobbelaere, D.; Jaeken, J.; Klein, A.; Cartigny, M.; Weill, J. Congenital disorder of glycosylation Ib (CDG-Ib) without gastrointestinal symptoms. J. Inherit. Metab. Dis. 2003, 26, 83-85. [CrossRef] [PubMed]

165. Damen, G.; de Klerk, H.; Huijmans, J.; den Hollander, J.; Sinaasappel, M. Gastrointestinal and other clinical manifestations in 17 children with congenital disorders of glycosylation type $\mathrm{Ia}, \mathrm{Ib}$, and Ic. J. Pediatr. Gastroenterol. Nutr. 2004, 38, 282-287. [CrossRef] [PubMed]

166. Jackson, M.; Clayton, P.; Grunewald, S.; Keir, G.; Mills, K.; Mills, P.; Winchester, B.; Worthington, V.; Young, E. Elevation of plasma aspartylglucosaminidase is a useful marker for the congenital disorders of glycosylation type I (CDG I). J. Inherit. Metab. Dis. 2005, 28, 1197-1198. [CrossRef] [PubMed]

167. Mills, K.; Mills, P.; Jackson, M.; Worthington, V.; Beesley, C.; Mann, A.; Clayton, P.; Grunewald, S.; Keir, G.; Young, L.; et al. Diagnosis of congenital disorders of glycosylation type-I using protein chip technology. Proteomics 2006, 6, 2295-2304. [CrossRef] [PubMed]

168. Mention, K.; Lacaille, F.; Valayannopoulos, V.; Romano, S.; Kuster, A.; Cretz, M.; Zaidan, H.; Galmiche, L.; Jaubert, F.; de Keyzer, Y.; et al. Development of liver disease despite mannose treatment in two patients with CDG-Ib. Mol. Genet. Metab. 2008, 93, 40-43. [CrossRef] [PubMed]

169. Miller, B.S.; Khosravi, M.J.; Patterson, M.C.; Conover, C.A. IGF system in children with congenital disorders of glycosylation. Clin. Endocrinol. (Oxf). 2009, 70, 892-897. [CrossRef] [PubMed]

170. Liem, Y.S.; Bode, L.; Freeze, H.H.; Leebeek, F.W.G.; Zandbergen, A.A.M.; Paul Wilson, J.H. Using heparin therapy to reverse protein-losing enteropathy in a patient with CDG-Ib. Nat. Clin. Pract. Gastroenterol. Hepatol. 2008, 5, 220-224. [CrossRef] [PubMed]

171. Janssen, M.C.H.; de Kleine, R.H.; van den Berg, A.P.; Heijdra, Y.; van Scherpenzeel, M.; Lefeber, D.J.; Morava, E. Successful Liver Transplantation and Long-Term Follow-up in a Patient With MPI-CDG. Pediatrics 2014, 134, e279-e283. [CrossRef] [PubMed]

172. Jaeken, J.; Matthijs, G.; Saudubray, J.-M.; Dionisi-Vici, C.; Bertini, E.; de Lonlay, P.; Henri, H.; Carchon, H.; Schollen, E.; Van Schaftingen, E. Phosphomannose Isomerase Deficiency: A Carbohydrate-Deficient Glycoprotein Syndrome with Hepatic-Intestinal Presentation. Am. J. Hum. Genet. 1998, 62, 1535-1539. [CrossRef] [PubMed] 
173. Schroeder, A.S.; Kappler, M.; Bonfert, M.; Borggraefe, I.; Schoen, C.; Reiter, K. Seizures and stupor during intravenous mannose therapy in a patient with CDG syndrome type 1b (MPI-CDG). J. Inherit. Metab. Dis. 2010, 33. [CrossRef] [PubMed]

174. He, P.; Ng, B.G.; Losfeld, M.E.; Zhu, W.; Freeze, H.H. Identification of intercellular cell adhesion molecule 1 (ICAM-1) as a hypoglycosylation marker in congenital disorders of glycosylation cells. J. Biol. Chem. 2012, 287, 18210-18217. [CrossRef] [PubMed]

175. He, P.; Srikrishna, G.; Freeze, H.H. N-glycosylation deficiency reduces ICAM-1 induction and impairs inflammatory response. Glycobiology 2014, 24, 392-398. [CrossRef] [PubMed]

176. Bengtson, P.; Ng, B.G.; Jaeken, J.; Matthijs, G.; Freeze, H.H.; Eklund, E.A. Serum transferrin carrying the xeno-tetrasaccharide NeuAc-Gal-GlcNAc2 is a biomarker of ALG1-CDG. J. Inherit. Metab. Dis. 2016, 39, 107-114. [CrossRef] [PubMed]

177. Burda, P.; Borsig, L.; de Rijk-Van Andel, J.; Wevers, R.; Jaeken, J.; Carchon, H.; Berger, E.G.; Aebi, M. A novel carbohydrate-deficient glycoprotein syndrome characterized by a deficiency in glucosylation of the dolichol-linked oligosaccharide. J. Clin. Investig. 1998, 102, 647-652. [CrossRef] [PubMed]

178. Zhang, W.; James, P.M.; Ng, B.G.; Li, X.; Xia, B.; Rong, J.; Asif, G.; Raymond, K.; Jones, M.A.; Hegde, M.; et al. A Novel $N$-Tetrasaccharide in Patients with Congenital Disorders of Glycosylation, Including Asparagine-Linked Glycosylation Protein 1, Phosphomannomutase 2, and Mannose Phosphate Isomerase Deficiencies. Clin. Chem. 2016, 62, 208-217. [CrossRef] [PubMed]

179. Losfeld, M.E.; Soncin, F.; Ng, B.G.; Singec, I.; Freeze, H.H. A sensitive green fluorescent protein biomarker of N-glycosylation site occupancy. FASEB J. 2012, 26, 4210-4217. [CrossRef] [PubMed]

180. Grünewald, S.; Huyben, K.; de Jong, J.G.; Smeitink, J.A.; Rubio, E.; Boers, G.H.; Conradt, H.S.; Wendel, U.; Wevers, R. A $\beta$-Trace protein in human cerebrospinal fluid: A diagnostic marker for $N$-glycosylation defects in brain. Biochim. Biophys. Acta 1999, 1455, 54-60. [CrossRef]

181. Wang, Z.; Sun, Z.; Li, A.V.; Yarema, K.J. Roles for UDP-GlcNAc 2-epimerase/ManNAc 6-kinase outside of sialic acid biosynthesis: Modulation of sialyltransferase and BiP expression, GM3 and GD3 biosynthesis, proliferation, and apoptosis, and ERK1/2 phosphorylation. J. Biol. Chem. 2006, 281, 27016-27028. [CrossRef] [PubMed]

182. Paccalet, T.; Coulombe, Z.; Tremblay, J.P. Ganglioside GM3 levels are altered in a mouse model of hibm: GM3 as a cellular marker of the disease. PLOS ONE 2010, 5. [CrossRef] [PubMed]

183. Valles-Ayoub, Y.; Esfandiarifard, S.; Sinai, P.; Carbajo, R.; Khokher, Z.; No, D.; Pietruszka, M.; Darvish, B.; Kakkis, E.; Darvish, D. Serum Neural Cell Adhesion Molecule Is Hyposialylated in Hereditary Inclusion Body Myopathy. Genet. Test. Mol. Biomark. 2012, 16, 313-317. [CrossRef] [PubMed]

184. Leoyklang, P.; Malicdan, M.C.; Yardeni, T.; Celeste, F.; Ciccone, C.; Li, X.; Jiang, R.; Gahl, W.A.; Carrillo-Carrasco, N.; He, M.; et al. Sialylation of Thomsen-Friedenreich antigen is a noninvasive blood-based biomarker for GNE myopathy. Biomark. Med. 2014, 8, 641-652. [CrossRef] [PubMed]

185. Zdebska, E.; Musielak, M.; Jaeken, J.; Kościelak, J. Band 3 glycoprotein and glycophorin A from erythrocytes of children with congenital disorder of glycosylation type-Ia are underglycosylated. Proteomics 2001, 1, 269-274. [CrossRef]

186. Sala, G.; Dupré, T.; Seta, N.; Codogno, P.; Ghidoni, R. Increased biosynthesis of glycosphingolipids in congenital disorder of glycosylation Ia (CDG-Ia) fibroblasts. Pediatr. Res. 2002, 52, 645-651. [CrossRef] [PubMed]

187. Harrison, H.H.; Miller, K.L.; Harbison, M.D.; Slonim, A.E. Multiple serum protein abnormalities in carbohydrate-deficient glycoprotein syndrome: Pathognomonic finding of two-dimensional electrophoresis? Clin. Chem. 1992, 38, 1390-1392. [PubMed]

188. Mohamed, M.; Theodore, M.; van der Grinten, H.C.; Van Herwaarden, A.E.; Huijben, K.; van Dongen, L.; Kouwenberg, D.; Lefeber, D.J.; Wevers, R.A.; Morava, E. Thyroid function in PMM2-CDG: Diagnostic approach and proposed management. Mol. Genet. Metab. 2012, 105, 681-683. [CrossRef] [PubMed]

189. Pohl, S.; Hoffmann, A.; Rüdiger, A.; Nimtz, M.; Jaeken, J.; Conradt, H.S. Hypoglycosylation of a brain glycoprotein ( $\beta$-trace protein) in CDG syndromes due to phosphomannomutase deficiency and $\mathrm{N}$-acetylglucosaminyl-transferase II deficiency. Glycobiology 1997, 7, 1077-1084. [CrossRef] [PubMed]

190. Gadomski, T.E.; Bolton, M.; Alfadhel, M.; Dvorak, C.; Ogunsakin, O.A.; Nelson, S.L.; Morava, E. ALG13-CDG in a male with seizures, normal cognitive development, and normal transferrin isoelectric focusing. Am. J. Med. Genet. Part A 2017, 173, 2772-2775. [CrossRef] [PubMed] 
191. Cromphout, K.; Vleugels, W.; Heykants, L.; Schollen, E.; Keldermans, L.; Sciot, R.; D’Hooge, R.; de Deyn, P.P.; von Figura, K.; Hartmann, D.; et al. The Normal Phenotype of Pmm1-Deficient Mice Suggests that Pmm1 Is Not Essential for Normal Mouse Development. Mol. Cell. Biol. 2006, 26, 5621-5635. [CrossRef] [PubMed]

192. Veiga-Da-Cunha, M.; Vleugels, W.; Maliekal, P.; Matthijs, G.; Van Schaftingen, E. Mammalian phosphomannomutase PMM1 is the brain IMP-sensitive glucose-1,6-bisphosphatase. J. Biol. Chem. 2008, 283, 33988-33993. [CrossRef] [PubMed]

193. Citro, V.; Cimmaruta, C.; Liguori, L.; Viscido, G.; Cubellis, M.V.; Andreotti, G. A mutant of phosphomannomutase1 retains full enzymatic activity, but is not activated by IMP: Possible implications for the disease PMM2-CDG. PLoS ONE 2017, 12, e0189629. [CrossRef] [PubMed]

194. Körner, C.; Lehle, L.; Von Figura, K. Carbohydrate-deficient glycoprotein syndrome type 1: Correction of the glycosylation defect by deprivation of glucose or supplementation of mannose. Glycoconj. J. 1998, 15, 499-505. [CrossRef] [PubMed]

195. Alton, G.; Kjaergaard, S.; Etchison, J.R.; Skovby, F.; Freeze, H.H. Oral ingestion of mannose elevates blood mannose levels: A first step toward a potential therapy for carbohydrate-deficient glycoprotein syndrome type I. Biochem. Mol. Med. 1997, 60, 127-133. [CrossRef] [PubMed]

196. Mayatepek, E.; Kohlmuller, D. Mannose supplementation in carbohydrate-deficient glycoprotein syndrome type I and phosphomannomutase deficiency. Eur. J. Pediatr. 1998, 157, 605-606. [CrossRef] [PubMed]

197. Mayatepek, E.; Schröder, M.; Kohlmüller, D.; Bieger, W.P.; Nützenadel, W. Continuous mannose infusion in carbohydrate-deficient glycoprotein syndrome type I. Acta Paediatr. 1997, 86, 1138-1140. [CrossRef] [PubMed]

198. Kjaergaard, S.; Kristiansson, B.; Stibler, H.; Freeze, H.H.; Schwartz, M.; Martinsson, T.; Skovby, F. Failure of short-term mannose therapy of patients with carbohydrate-deficient glycoprotein syndrome type 1A. Acta Paediatr. 1998, 87, 884-888. [CrossRef] [PubMed]

199. Marquardt, T.; Denecke, J. Congenital disorders of glycosylation: Review of their molecular bases, clinical presentations and specific therapies. Eur. J. Pediatr. 2003, 162, 359-379. [CrossRef] [PubMed]

200. Shang, J.; Lehrman, M.A. Metformin-stimulated Mannose Transport in Dermal Fibroblasts. J. Biol. Chem. 2004, 279, 9703-9712. [CrossRef] [PubMed]

201. Rutschow, S.; Thiem, J.; Kranz, C.; Marquardt, T. Membrane-permeant derivatives of mannose-1-phosphate. Bioorg. Med. Chem. 2002, 10, 4043-4049. [CrossRef]

202. Eklund, E.A.; Merbouh, N.; Ichikawa, M.; Nishikawa, A.; Clima, J.M.; Dorman, J.A.; Norberg, T.; Freeze, H.H. Hydrophobic Man-1-P derivatives correct abnormal glycosylation in Type I congenital disorder of glycosylation fibroblasts. Glycobiology 2005, 15, 1084-1093. [CrossRef] [PubMed]

203. Hardré, R.; Khaled, A.; Willemetz, A.; Dupré, T.; Moore, S.; Gravier-Pelletier, C.; Merrer, Y. le Mono, di and tri-mannopyranosyl phosphates as mannose-1-phosphate prodrugs for potential CDG-Ia therapy. Bioorg. Med. Chem. Lett. 2007, 17, 152-155. [CrossRef] [PubMed]

204. Glycomine. Available online: http:/ / glycomine.com/ (accessed on 19 January 2018).

205. Balasubramaniam, S.; Duley, J.A.; Christodoulou, J. Inborn errors of pyrimidine metabolism: Clinical update and therapy. J. Inherit. Metab. Dis. 2014, 37, 687-698. [CrossRef] [PubMed]

206. Hinderlich, S.; Berger, M.; Keppler, O.T.; Pawlita, M.; Reutter, W. Biosynthesis of N-acetylneuraminic acid in cells lacking UDP- $N$-acetylglucosamine 2-epimerase/ $N$-acetylmannosamine kinase. Biol. Chem. 2001, 382, 291-297. [CrossRef] [PubMed]

207. Pham, N.D.; Pang, P.C.; Krishnamurthy, S.; Wands, A.M.; Grassi, P.; Dell, A.; Haslam, S.M.; Kohler, J.J. Effects of altered sialic acid biosynthesis on N-linked glycan branching and cell surface interactions. J. Biol. Chem. 2017, 292, 9637-9651. [CrossRef] [PubMed]

208. Wong, S.Y.W.; Gadomski, T.; Van Scherpenzeel, M.; Honzik, T.; Hansikova, H.; Holmefjord, K.S.B.; Mork, M.; Bowling, F.; Sykut-Cegielska, J.; Koch, D.; et al. Oral D-galactose supplementation in PGM1-CDG. Genet. Med. 2017, 19, 1226-1235. [CrossRef] [PubMed]

209. Schrapers, E.; Tegtmeyer, L.C.; Simic-Schleicher, G.; Debus, V.; Reunert, J.; Balbach, S.; Klingel, K.; Du Chesne, I.; Seelhöfer, A.; Fobker, M.; et al. News on Clinical Details and Treatment in PGM1-CDG. JIMD Rep. 2016, 26, 77-84. [CrossRef] [PubMed]

210. Nolting, K.; Park, J.H.; Tegtmeyer, L.C.; Zühlsdorf, A.; Grüneberg, M.; Rust, S.; Reunert, J.; Du Chesne, I.; Debus, V.; Schulze-Bahr, E.; et al. Limitations of galactose therapy in phosphoglucomutase 1 deficiency. Mol. Genet. Metab. Rep. 2017, 13, 33-40. [CrossRef] [PubMed] 
211. Preisler, N.; Laforêt, P.; Echaniz-Laguna, A.; Ørngreen, M.C.; Lonsdorfer-Wolf, E.; Doutreleau, S.; Geny, B.; Stojkovic, T.; Piraud, M.; Petit, F.M.; et al. Fat and Carbohydrate Metabolism During Exercise in Phosphoglucomutase Type 1 Deficiency. J. Clin. Endocrinol. Metab. 2013, 98, E1235-E1240. [CrossRef] [PubMed]

212. Voermans, N.C.; Preisler, N.; Madsen, K.L.; Janssen, M.C.H.; Kusters, B.; Abu Bakar, N.; Conte, F.; Lamberti, V.M.L.; Nusman, F.; van Engelen, B.G.; et al. PGM1 deficiency: Substrate use during exercise and effect of treatment with galactose. Neuromuscul. Disord. 2017, 27, 370-376. [CrossRef] [PubMed]

213. Pang, H.; Koda, Y.; Soejima, M.; Kimura, H. Identification of human phosphoglucomutase 3 (PGM3) as $\mathrm{N}$-acetylglucosamine-phosphate mutase (AGM1). Ann. Hum. Genet. 2002, 66, 139-144. [CrossRef] [PubMed]

214. Cherepanova, N.A.; Gilmore, R. Mammalian cells lacking either the cotranslational or posttranslocational oligosaccharyltransferase complex display substrate-dependent defects in asparagine linked glycosylation. Sci. Rep. 2016, 6, 20946. [CrossRef] [PubMed]

215. Patiroglu, T.; Haluk Akar, H.; Gilmour, K.; Unal, E.; Akif Ozdemir, M.; Bibi, S.; Burns, S.; Chiang, S.C.; Schlums, H.; Bryceson, Y.T.; et al. A case of XMEN syndrome presented with severe auto-immune disorders mimicking autoimmune lymphoproliferative disease. Clin. Immunol. 2015, 159, 58-62. [CrossRef] [PubMed]

216. Joshi, C.; Kolbe, D.L.; Mansilla, M.A.; Mason, S.; Smith, R.J.H.; Campbell, C.A. Ketogenic diet-A novel treatment for early epileptic encephalopathy due to PIGA deficiency. Brain Dev. 2016, 38, 848-851. [CrossRef] [PubMed]

217. Neal, E.G.; Chaffe, H.; Schwartz, R.H.; Lawson, M.S.; Edwards, N.; Fitzsimmons, G.; Whitney, A.; Cross, J.H. The ketogenic diet for the treatment of childhood epilepsy: A randomised controlled trial. Lancet Neurol. 2008, 7, 500-506. [CrossRef]

218. Taha, A.Y.; Burnham, W.M.; Auvin, S. Polyunsaturated fatty acids and epilepsy. Epilepsia 2010, 51, 1348-1358. [CrossRef] [PubMed]

219. Almeida, A.; Layton, M.; Karadimitris, A. Inherited glycosylphosphatidyl inositol deficiency: A treatable CDG. Biochim. Biophys. Acta Mol. Basis Dis. 2009, 1792, 874-880. [CrossRef] [PubMed]

220. Kuki, I.; Takahashi, Y.; Okazaki, S.; Kawawaki, H.; Ehara, E.; Inoue, N.; Kinoshita, T.; Murakami, Y. Vitamin B6-responsive epilepsy due to inherited GPI deficiency. Neurology 2013, 81, 1467-1469. [CrossRef] [PubMed]

221. Ng, B.G.; Buckingham, K.J.; Raymond, K.; Kircher, M.; Turner, E.H.; He, M.; Smith, J.D.; Eroshkin, A.; Szybowska, M.; Losfeld, M.E.; et al. Mosaicism of the UDP-galactose transporter SLC35A2 causes a congenital disorder of glycosylation. Am. J. Hum. Genet. 2013, 92, 632-636. [CrossRef] [PubMed]

222. Etzioni, A.; Sturla, L.; Antonellis, A.; Green, E.D.; Gershoni-Baruch, R.; Berninsone, P.M.; Hirschberg, C.B.; Tonetti, M. Leukocyte adhesion deficiency (LAD) type II/carbohydrate deficient glycoprotein (CDG) IIC founder effect and genotype/phenotype correlation. Am. J. Med. Genet. 2002, 110, 131-135. [CrossRef] [PubMed]

223. Etzioni, A.; Tonetti, M. Fucose supplementation in leukocyte adhesion deficiency type II. Blood 2000, 95, 3641-3643. [PubMed]

224. Jansen, J.C.; Cirak, S.; van Scherpenzeel, M.; Timal, S.; Reunert, J.; Rust, S.; Pérez, B.; Vicogne, D.; Krawitz, P.; Wada, Y.; et al. CCDC115 Deficiency Causes a Disorder of Golgi Homeostasis with Abnormal Protein Glycosylation. Am. J. Hum. Genet. 2016, 98, 310-321. [CrossRef] [PubMed]

225. Jansen, J.C.; Timal, S.; Van Scherpenzeel, M.; Michelakakis, H.; Vicogne, D.; Ashikov, A.; Moraitou, M.; Hoischen, A.; Huijben, K.; Steenbergen, G.; et al. TMEM199 Deficiency is a Disorder of Golgi Homeostasis Characterized by Elevated Aminotransferases, Alkaline Phosphatase, and Cholesterol and Abnormal Glycosylation. Am. J. Hum. Genet. 2016, 98, 322-330. [CrossRef] [PubMed]

226. Riley, L.G.; Cowley, M.J.; Gayevskiy, V.; Roscioli, T.; Thorburn, D.R.; Prelog, K.; Bahlo, M.; Sue, C.M.; Balasubramaniam, S.; Christodoulou, J. A SLC39A8 variant causes manganese deficiency, and glycosylation and mitochondrial disorders. J. Inherit. Metab. Dis. 2017, 40, 261-269. [CrossRef] [PubMed]

227. Park, J.H.; Hogrebe, M.; Grüneberg, M.; Duchesne, I.; von der Heiden, A.L.; Reunert, J.; Schlingmann, K.P.; Boycott, K.M.; Beaulieu, C.L.; Mhanni, A.A.; et al. SLC39A8 Deficiency: A Disorder of Manganese Transport and Glycosylation. Am. J. Hum. Genet. 2015, 97, 894-903. [CrossRef] [PubMed]

228. Park, J.H.; Hogrebe, M.; Fobker, M.; Brackmann, R.; Fiedler, B.; Reunert, J.; Rust, S.; Tsiakas, K.; Santer, R.; Grüneberg, M.; et al. SLC39A8 deficiency: Biochemical correction and major clinical improvement by manganese therapy. Genet. Med. 2017, 20, 259-268. [CrossRef] [PubMed] 
229. Gámez, A.; Yuste-Checa, P.; Brasil, S.; Briso-Montiano, Á.; Desviat, L.R.; Ugarte, M.; Pérez-Cerdá, C.; Pérez, B. Protein misfolding diseases: Prospects of pharmacological treatment. Clin. Genet. 2017, 93, 450-458. [CrossRef] [PubMed]

230. Brasil, S.; Briso-Montiano, A.; Gámez, A.; Underhaug, J.; Flydal, M.I.; Desviat, L.; Merinero, B.; Ugarte, M.; Martinez, A.; Pérez, B. New perspectives for pharmacological chaperoning treatment in methylmalonic aciduria cblB type. Biochim. Biophys. Acta Mol. Basis Dis. 2018, 1864, 640-648. [CrossRef] [PubMed]

231. Yuste-Checa, P.; Brasil, S.; Gámez, A.; Underhaug, J.; Desviat, L.R.; Ugarte, M.; Pérez-Cerdá, C.; Martinez, A.; Pérez, B. Pharmacological Chaperoning: A Potential Treatment for PMM2-CDG. Hum. Mutat. 2017, 38, 160-168. [CrossRef] [PubMed]

232. Andreotti, G.; de Vaca, I.C.; Poziello, A.; Monti, M.C.; Guallar, V.; Cubellis, M.V. Conformational response to ligand binding in Phosphomannomutase2: Insights into inborn glycosylation disorder. J. Biol. Chem. 2014, 289, 34900-34910. [CrossRef] [PubMed]

233. Vega, A.I.; Pérez-Cerdá, C.; Abia, D.; Gámez, A.; Briones, P.; Artuch, R.; Desviat, L.R.; Ugarte, M.; Pérez, B. Expression analysis revealing destabilizing mutations in phosphomannomutase 2 deficiency (PMM2-CDG): Expression analysis of PMM2-CDG mutations. J. Inherit. Metab. Dis. 2011, 34, 929-939. [CrossRef] [PubMed]

234. Andreotti, G.; Pedone, E.; Giordano, A.; Cubellis, M.V. Biochemical phenotype of a common disease-causing mutation and a possible therapeutic approach for the phosphomannomutase 2-associated disorder of glycosylation. Mol. Genet. Genom. Med. 2013, 1, 32-44. [CrossRef] [PubMed]

235. Yuste-Checa, P.; Gámez, A.; Brasil, S.; Desviat, L.R.; Ugarte, M.; Pérez-Cerdá, C.; Pérez, B. The Effects of PMM2-CDG-Causing Mutations on the Folding, Activity, and Stability of the PMM2 Protein. Hum. Mutat. 2015, 36, 851-860. [CrossRef] [PubMed]

236. Andreotti, G.; Monti, M.C.; Citro, V.; Cubellis, M.V. Heterodimerization of two pathological mutants enhances the activity of human phosphomannomutase2. PLoS ONE 2015, 10, e0139882. [CrossRef] [PubMed]

237. Dahl, R.; Bravo, Y.; Sharma, V.; Ichikawa, M.; Dhanya, R.-P.; Hedrick, M.; Brown, B.; Rascon, J.; Vicchiarelli, M.; Mangravita-Novo, A.; et al. Potent, Selective, and Orally Available Benzoisothiazolone Phosphomannose Isomerase Inhibitors as Probes for Congenital Disorder of Glycosylation Ia. J. Med. Chem. 2011, 54, 3661-3668. [CrossRef] [PubMed]

238. Yuste-Checa, P.; Medrano, C.; Gámez, A.; Desviat, L.R.; Matthijs, G.; Ugarte, M.; Pérez-Cerdá, C.; Pérez, B. Antisense-mediated therapeutic pseudoexon skipping in TMEM165-CDG. Clin. Genet. 2015, 87, 42-48. [CrossRef] [PubMed]

239. Vega, A.I.; Perez-Cerda, C.; Desviat, L.R.; Matthijs, G.; Ugarte, M.; Pérez, B. Functional analysis of three splicing mutations identified in the PMM2 gene: Toward a new therapy for congenital disorder of glycosylation type IA. Hum. Mutat. 2009, 30, 795-803. [CrossRef] [PubMed]

240. Vuillaumier-Barrot, S.; Barnier, A.; Cuer, M.; Durand, G.; Grandchamp, B.; Seta, N. Characterization of the 415G >A (E139K) PMM2 mutation in carbohydrate-deficient glycoprotein syndrome type Ia disrupting a splicing enhancer resulting in exon 5 skipping. Hum. Mutat. 1999, 14, 543-544. [CrossRef]

241. Vuillaumier-Barrot, S.; Le Bizec, C.; De Lonlay, P.; Madinier-Chappat, N.; Barnier, A.; Dupré, T.; Durand, G.; Seta, N. PMM2 intronic branch-site mutations in CDG-Ia. Mol. Genet. Metab. 2006, 87, 337-340. [CrossRef] [PubMed]

242. Bryson, T.E.; Anglin, C.M.; Bridges, P.H.; Cottle, R.N. Nuclease-Mediated Gene Therapies for Inherited Metabolic Diseases of the Liver. Yale J. Biol. Med. 2017, 90, 553-566. [PubMed]

243. Malicdan, M.C.; Okada, T.; Sela, I.; Takeda, S.; Funato, F.; Nonaka, I.; Hayashi, Y.K.; Yakovlev, L.; Argov, Z.; Nishino, I.; et al. P4.46 Expression of human GNE through adeno-associated virus mediated therapy delays progression of myopathy in the DMRV/hIBM mouse model. Neuromuscul. Disord. 2011, 21, 718. [CrossRef]

244. Tal-Goldberg, T.; Lorain, S.; Mitrani-Rosenbaum, S. Correction of the Middle Eastern M712T mutation causing GNE myopathy by trans-splicing. NeuroMol. Med. 2014, 16, 322-331. [CrossRef] [PubMed]

245. Meliani, A.; Boisgerault, F.; Fitzpatrick, Z.; Marmier, S.; Leborgne, C.; Collaud, F.; Simon Sola, M.; Charles, S.; Ronzitti, G.; Vignaud, A.; et al. Enhanced liver gene transfer and evasion of preexisting humoral immunity with exosome-enveloped AAV vectors. Blood Adv. 2017, 1, 2019-2031. [CrossRef] [PubMed]

246. Phadke, A.P.; Jay, C.; Chen, S.J.; Haddock, C.; Wang, Z.; Yu, Y.; Nemunaitis, D.; Nemunaitis, G.; Templeton, N.S.; Senzer, N.; et al. Safety and in vivo expression of a GNE-transgene: A novel treatment approach for hereditary inclusion body myopathy-2. Gene Regul. Syst. Biol. 2009, 3, 89-101. [CrossRef] 
247. Nemunaitis, G.; Jay, C.M.; Maples, P.B.; Gahl, W.A.; Huizing, M.; Yardeni, T.; Tong, A.W.; Phadke, A.P.; Pappen, B.O.; Bedell, C.; et al. Hereditary Inclusion Body Myopathy: Single Patient Response to Intravenous Dosing of GNE Gene Lipoplex. Hum. Gene Ther. 2011, 22, 1331-1341. [CrossRef] [PubMed]

248. Nemunaitis, G.; Maples, P.B.; Jay, C.; Gahl, W.A.; Huizing, M.; Poling, J.; Tong, A.W.; Phadke, A.P.; Pappen, B.O.; Bedell, C.; et al. Hereditary inclusion body myopathy: Single patient response to GNE gene Lipoplex therapy. J. Gene Med. 2010, 12, 403-412. [CrossRef] [PubMed]

249. Halldorson, J.; Kazi, Z.; Mekeel, K.; Kuo, A.; Hassanein, T.; Loomba, R.; Austin, S.; Valasek, M.A.; Kishnani, P.; Hemming, A.W. Successful combined liver/kidney transplantation from a donor with Pompe disease. Mol. Genet. Metab. 2015, 115, 141-144. [CrossRef] [PubMed]

250. Oishi, K.; Arnon, R.; Wasserstein, M.P.; Diaz, G.A. Liver transplantation for pediatric inherited metabolic disorders: Considerations for indications, complications, and perioperative management. Pediatr. Transplant. 2016, 20, 756-769. [CrossRef] [PubMed]

251. Dalle, J.-H.; de Latour, R.P. Allogeneic hematopoietic stem cell transplantation for inherited bone marrow failure syndromes. Int. J. Hematol. 2016, 103, 373-379. [CrossRef] [PubMed]

252. Kapusta, L.; Zucker, N.; Frenckel, G.; Medalion, B.; Ben Gal, T.; Birk, E.; Mandel, H.; Nasser, N.; Morgenstern, S.; Zuckermann, A.; Lefeber, D.J.; et al. From discrete dilated cardiomyopathy to successful cardiac transplantation in congenital disorders of glycosylation due to dolichol kinase deficiency (DK1-CDG). Heart Fail. Rev. 2013, 18, 187-196. [CrossRef] [PubMed]

253. Klcovansky, J.; Mørkrid, L.; Möller, T. Heart transplantation in a child with congenital disorder of glycosylation. J. Hear. Lung Transplant. 2016, 35, 1048-1049. [CrossRef] [PubMed]

254. Giannuzzi, V.; Devlieger, H.; Margari, L.; Odlind, V.L.; Ragab, L.; Bellettato, C.M.; D’Avanzo, F.; Lampe, C.; Cassis, L.; Cortès-Saladelafont, E.; et al. The ethical framework for performing research with rare inherited neurometabolic disease patients. Eur. J. Pediatr. 2017, 176, 395-405. [CrossRef] [PubMed]

255. Phoenix, C.; Schaefer, A.M.; Elson, J.L.; Morava, E.; Bugiani, M.; Uziel, G.; Smeitink, J.A.; Turnbull, D.M.; McFarland, R. A scale to monitor progression and treatment of mitochondrial disease in children. Neuromuscul. Disord. 2006, 16, 814-820. [CrossRef] [PubMed]

256. Achouitar, S.; Mohamed, M.; Gardeitchik, T.; Wortmann, S.B.; Sykut-Cegielska, J.; Ensenauer, R.; De Baulny, H.O.; Õunap, K.; Martinelli, D.; De Vries, M.; et al. Nijmegen paediatric CDG rating scale: A novel tool to assess disease progression. J. Inherit. Metab. Dis. 2011, 34, 923-927. [CrossRef] [PubMed]

257. Serrano, M.; De Diego, V.; Muchart, J.; Cuadras, D.; Felipe, A.; Macaya, A.; Velázquez, R.; Poo, M.P.; Fons, C.; O'Callaghan, M.M.; et al. Phosphomannomutase deficiency (PMM2-CDG): Ataxia and cerebellar assessment. Orphanet J. Rare Dis. 2015, 10, 138. [CrossRef] [PubMed]

258. Serrano, N.L.; De Diego, V.; Cuadras, D.; Martinez Monseny, A.F.; Velázquez-Fragua, R.; López, L.; Felipe, A.; Gutiérrez-Solana, L.G.; Macaya, A.; Pérez-Dueñas, B.; et al. A quantitative assessment of the evolution of cerebellar syndrome in children with phosphomannomutase-deficiency (PMM2-CDG). Orphanet J. Rare Dis. 2017, 12, 10-15. [CrossRef] [PubMed]

259. De Diego, V.; Martínez-Monseny, A.F.; Muchart, J.; Cuadras, D.; Montero, R.; Artuch, R.; Pérez-Cerdá, C.; Pérez, B.; Pérez-Dueñas, B.; Poretti, A.; et al. Longitudinal volumetric and 2D assessment of cerebellar atrophy in a large cohort of children with phosphomannomutase deficiency (PMM2-CDG). J. Inherit. Metab. Dis. 2017, 40, 709-713. [CrossRef] [PubMed]

260. Wong, S.Y.W.; Gadomski, T.; Kozicz, T.; Morava, E.; Beamer, L.J.; Honzik, T.; Mohamed, M.; Morava, E.; Wortmann, S.B.; Brocke Holmefjord, K.S.; et al. Defining the Phenotype and Assessing Severity in Phosphoglucomutase-1 Deficiency. J. Pediatr. 2016, 175, 130-136.e8. [CrossRef] [PubMed]

261. Skrinar, A.M.; Argov, Z.; Caraco, Y.; Kolodny, E.; Lau, H.; Pestronk, A.; Shieh, P.; Bronstein, F.; Esposito, A.; Feinsod-Meiri, Y.; et al. P.3.1 GNE myopathy functional activity scale (GNEM-FAS): Development of a disease-specific instrument for measuring function and independence. Neuromuscul. Disord. 2013, 23, 755. [CrossRef]

262. Mori-Yoshimura, M.; Oya, Y.; Yajima, H.; Yonemoto, N.; Kobayashi, Y.; Hayashi, Y.K.; Noguchi, S.; Nishino, I.; Murata, M. GNE myopathy: A prospective natural history study of disease progression. Neuromuscul. Disord. 2014, 24, 380-386. [CrossRef] [PubMed]

263. Mori-Yoshimura, M.; Hayashi, Y.K.; Yonemoto, N.; Nakamura, H.; Murata, M.; Takeda, S.; Nishino, I.; Kimura, E. Nationwide patient registry for GNE myopathy in Japan. Orphanet J. Rare Dis. 2014, 9, 150. [CrossRef] [PubMed] 
264. Xu, X.; Wang, A.Q.; Latham, L.L.; Celeste, F.; Ciccone, C.; Malicdan, M.C.; Goldspiel, B.; Terse, P.; Cradock, J.; Yang, N.; et al. Safety, pharmacokinetics and sialic acid production after oral administration of N-acetylmannosamine (ManNAc) to subjects with GNE myopathy. Mol. Genet. Metab. 2017, 122, 126-134. [CrossRef] [PubMed]

265. Argov, Z.; Caraco, Y.; Lau, H.; Pestronk, A.; Shieh, P.B.; Skrinar, A.; Koutsoukos, T.; Ahmed, R.; Martinisi, J.; Kakkis, E. Aceneuramic Acid Extended Release Administration Maintains Upper Limb Muscle Strength in a 48-week Study of Subjects with GNE Myopathy: Results from a Phase 2, Randomized, Controlled Study. J. Neuromuscul. Dis. 2016, 3, 49-66. [CrossRef] [PubMed]

266. Sparks, S.; Rakocevic, G.; Joe, G.; Manoli, I.; Shrader, J.; Harris-Love, M.; Sonies, B.; Ciccone, C.; Dorward, H.; Krasnewich, D.; et al. Intravenous immune globulin in hereditary inclusion body myopathy: A pilot study. BMC Neurol. 2007, 7, 3. [CrossRef] [PubMed]

267. Home-ClinicalTrials.gov. Available online: https:/ / clinicaltrials.gov/ (accessed on 6 January 2018).

268. Clinical Trials Register. Available online: https://www.clinicaltrialsregister.eu/ctr-search/search (accessed on 9 January 2018).

269. Wang, Y.; Schachter, H.; Marth, J.D. Mice with a homozygous deletion of the Mgat2 gene encoding UDP- $N$-acetylglucosamine: $\alpha$-6-D-mannoside $\beta 1,2-N$-acetylglucosaminyltransferase II: A model for congenital disorder of glycosylation type IIa. Biochim. Biophys. Acta Gen. Subj. 2002, 1573, 301-311. [CrossRef]

270. Lühn, K.; Marquardt, T.; Harms, E.; Vestweber, D. Discontinuation of fucose therapy in LADII causes rapid loss of selectin ligands and rise of leukocyte counts. Blood 2001, 97, 330-332. [CrossRef] [PubMed]

271. Pritchard, J.-L. E.; O'Mara, T.A.; Glubb, D.M. Enhancing the Promise of Drug Repositioning through Genetics. Front. Pharmacol. 2017, 8, 896. [CrossRef] [PubMed]

272. EURORDIS. Eurordis Breaking the Access Deadlock to Leave No One Behind; A Reflection Paper by EURORDIS and Its Members; EURORDIS: Paris, France, 2017; pp. 1-47.

273. Zhao, M.; Wei, D.-Q. Rare Diseases: Drug Discovery and Informatics Resource. Interdiscip. Sci. Comput. Life Sci. 2017. [CrossRef] [PubMed]

274. Zamami, Y.; Imanishi, M.; Takechi, K.; Ishizawa, K. Pharmacological approach for drug repositioning against cardiorenal diseases. J. Med. Investig. 2017, 64, 197-201. [CrossRef] [PubMed]

275. Leaf, D.E.; Goldfarb, D.S. Mechanisms of action of acetazolamide in the prophylaxis and treatment of acute mountain sickness. J. Appl. Physiol. 2007, 102, 1313-1322. [CrossRef] [PubMed]

276. Hong, E.H.; Ahn, S.J.; Lim, H.W.; Lee, B.R. The effect of oral acetazolamide on cystoid macular edema in hydroxychloroquine retinopathy: A case report. BMC Ophthalmol. 2017, 17, 124. [CrossRef] [PubMed]

277. Finer, G.; Price, H.E.; Shore, R.M.; White, K.E.; Langman, C.B. Hyperphosphatemic familial tumoral calcinosis: Response to acetazolamide and postulated mechanisms. Am. J. Med. Genet. Part A 2014, 164, 1545-1549. [CrossRef] [PubMed]

278. Salman, M.S. Epidemiology of Cerebellar Diseases and Therapeutic Approaches. Cerebellum 2017, 17, 4-11. [CrossRef] [PubMed]

279. Westphal, V.; Kjaergaard, S.; Schollen, E.; Martens, K.; Grunewald, S.; Schwartz, M.; Matthijs, G.; Freeze, H.H. A frequent mild mutation in ALG6 may exacerbate the clinical severity of patients with congenital disorder of glycosylation Ia (CDG-Ia) caused by phosphomannomutase deficiency. Hum. Mol. Genet. 2002, 11, 599-604. [CrossRef] [PubMed]

280. Sabry, S.; Vuillaumier-Barrot, S.; Mintet, E.; Fasseu, M.; Valayannopoulos, V.; Héron, D.; Dorison, N.; Mignot, C.; Seta, N.; Chantret, I.; et al. A case of fatal Type I congenital disorders of glycosylation (CDG I) associated with low dehydrodolichol diphosphate synthase (DHDDS) activity. Orphanet J. Rare Dis. 2016, 11, 84. [CrossRef] [PubMed]

281. PubMed-NCBI. Available online: https:/ / www.ncbi.nlm.nih.gov/pubmed/ (accessed on 21 January 2018).

(C) 2018 by the authors. Licensee MDPI, Basel, Switzerland. This article is an open access article distributed under the terms and conditions of the Creative Commons Attribution (CC BY) license (http://creativecommons.org/licenses/by/4.0/). 